Project No.: 32780

\title{
Materials and Fuels Complex West Campus Utility Corridor Preliminary Engineering Report
}

\section{March 2018}

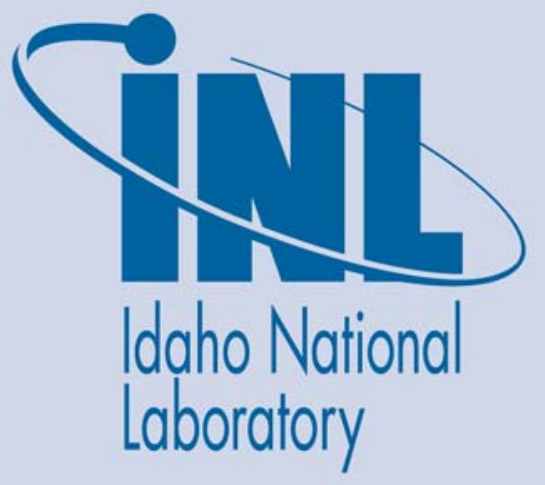

The INL is a U.S. Department of Energy National Laboratory operated by Battelle Energy Alliance

Prepared for the Idaho National Laboratory by:
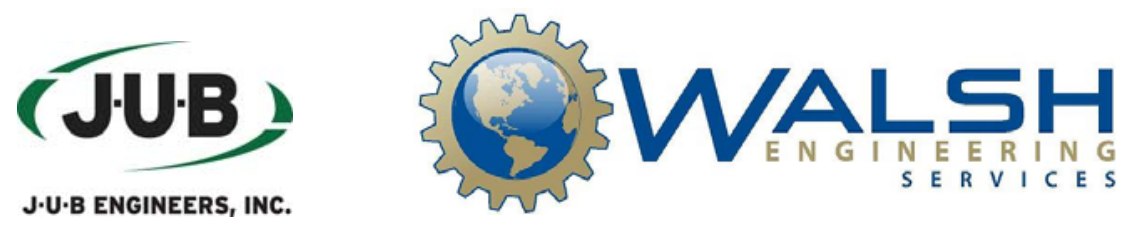
This page is left intentionally blank 
INL/EXT-18-44789

Revision: 0

\section{Materials and Fuels Complex West Campus Utility Corridor Preliminary Engineering Report}

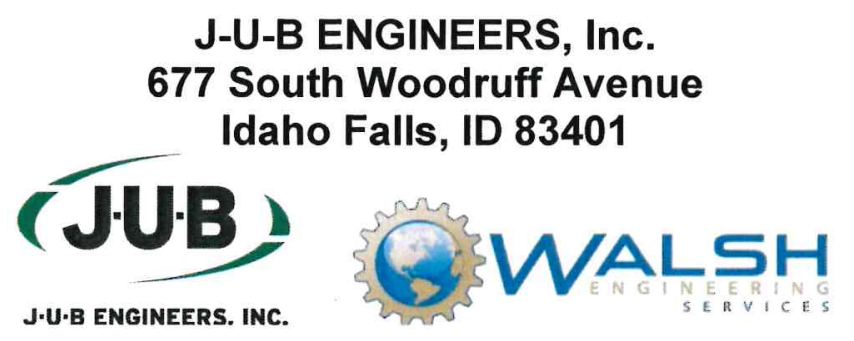

March 2018

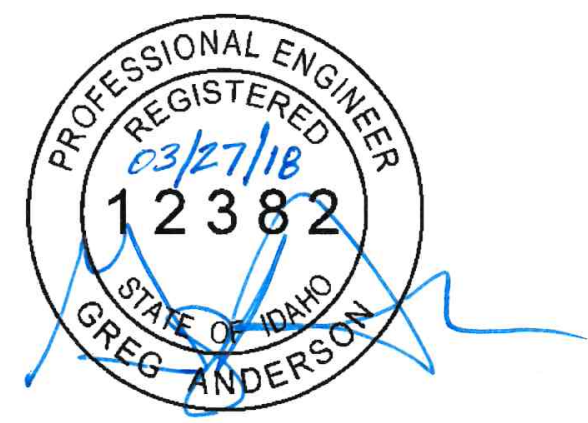

Prepared for the

U.S. Department of Energy

Office of Nuclear Energy

Under DOE Idaho Operations Office

Contract DE-AC07-05ID14517 
This page is left intentionally blank 


\section{Table of Contents}

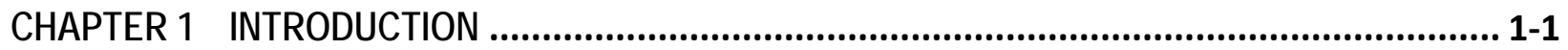

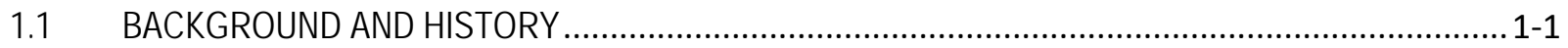

1.2 PURPOSE AND NEED ........................................................................................... $1-1$

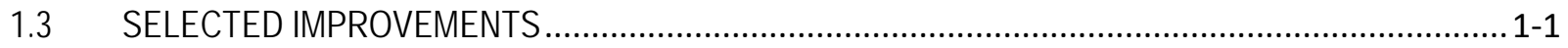

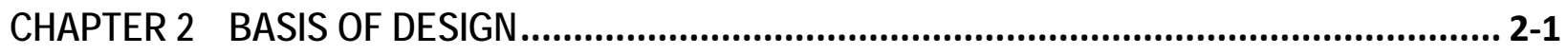

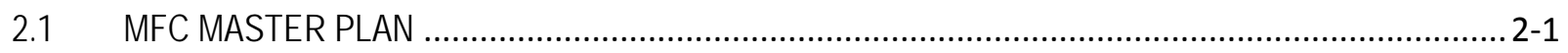

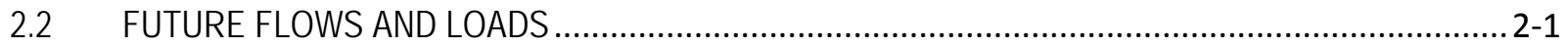

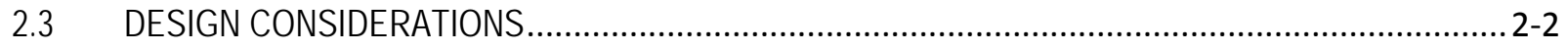

2.3.1 Existing Lagoon Capacity................................................................................ 2-2

2.3.2 Geotechnical Investigation ................................................................................. 2-2

2.3.3 Environmental Considerations................................................................................2-3

2.3.4 Safety Considerations........................................................................................ 2-3

2.3.5 Security and Safeguards Considerations ................................................................... 2-3

2.3.6 Operations and Maintenance..................................................................................... 2-3

2.3.7 Applicable Standards, Codes, and Permits ................................................................ 2-3

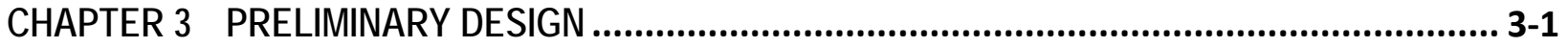

3.1 PRESSURE AND GRAVITY SEWER MAINS …………....................................................

3.1.1 Description and Layout ........................................................................................ $3-1$

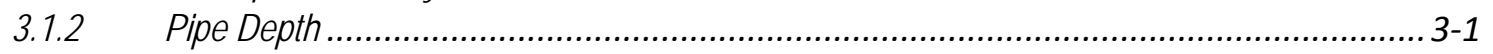

3.1.3 Utilities Crossing Considerations..............................................................................

3.1.4 Preliminary Design Criteria................................................................................... $3-2$

3.1.5 Corrosion Protection .........................................................................................

3.1.6 Odor Control..................................................................................................

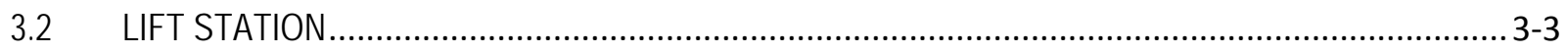

3.2.1 Description and Layout ....................................................................................

3.2.2 Preliminary Design Criteria...................................................................................

3.2.3 Flow Measurement.................................................................................. $3-4$

3.2.4 Controls and Operation .................................................................................. $3-4$

3.2.5 Buoyancy Considerations ................................................................................. $3-4$

3.2.6 Flooding Potential ..................................................................................... $3-5$

3.2.7 Odor Potential................................................................................................. $3-5$

3.2.8 Consideration of Future Expansion ……………………..................................... $3-5$

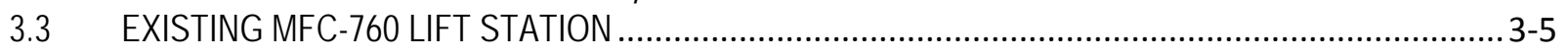

CHAPTER 4 PROJECT COSTS AND SCHEDULE................................................................... 4-1

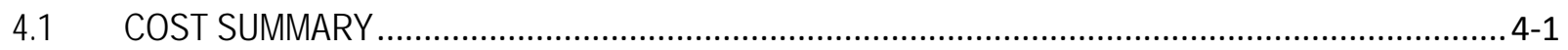

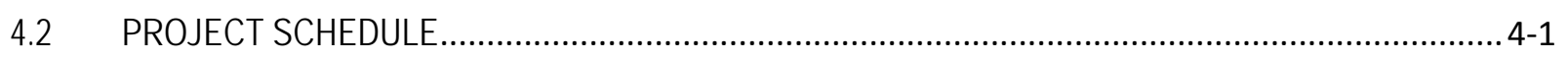

\section{APPENDICES}

Appendix A - Preliminary Design Drawings

Appendix B - Geotechnical Reports

Appendix C - Preliminary Design Calculations 
This page is left intentionally blank 


\section{LIST OF TABLES}

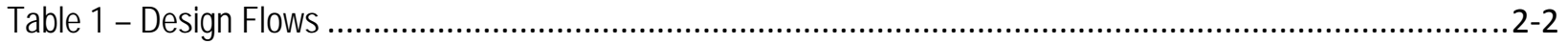

Table 2 - Gravity Collection System Preliminary Design Criteria................................................................. 3-2

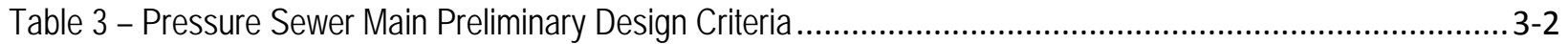

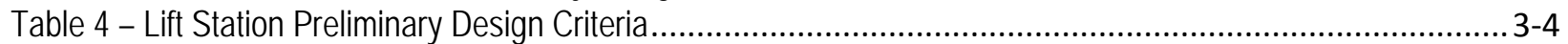

Table 5 - Opinion of Probable Construction Costs ..................................................................................... 4-1

Table 6 - Preliminary Project Schedule ........................................................................................ 4

\section{LIST OF FIGURES}

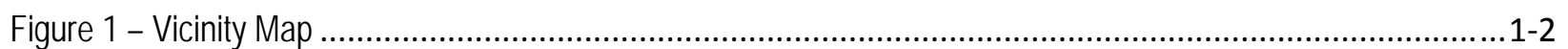

Figure 2 - MFC West Campus Utility Corridor Improvements ............................................................... 1-3 
This page is left intentionally blank 


\section{Chapter 1}

\section{Introduction}




\section{CHAPTER 1 INTRODUCTION}

\subsection{BACKGROUND AND HISTORY}

The Materials and Fuels Complex (MFC) is located in Bingham County, Idaho at the Idaho National Laboratory (INL). MFC is operated for the United States Department of Energy (DOE) by Battelle Energy Alliance, LLC (BEA). Walsh Engineering Services, PC (Walsh) is contracted by BEA to provide facility engineering services for MFC. J-U-B ENGINEERS, Inc. (J-U-B) has been subcontracted by Walsh to develop this Preliminary Engineering Report (PER) to evaluate the existing system and to develop preliminary improvements for addressing future growth and regulatory requirements. This PER will provide MFC with the information necessary to make sound decisions regarding future improvements to the facility.

The MFC Complex has an existing sanitary sewer system to collect and treat domestic wastewater from the facility. A majority of the facility is served for wastewater by a collection system consisting of gravity sewers and several lift stations and force mains. The collected wastewater is eventually conveyed to a central lift station (MFC-778) which pumps the wastewater to three total containment sewage lagoons for final disposal and evaporation. There are some small areas of MFC that are serviced by local onsite subsurface disposal systems and are independent of the wastewater collection system.

Figure 1 provides a vicinity map for the MFC area.

\subsection{PURPOSE AND NEED}

The current MFC wastewater system provides reliable and adequate disposal to the facilities within MFC; however, in anticipation of immediate and future growth, MFC desires to make upgrades to accommodate increased staffing levels and additional facilities at the complex.

\subsection{SELECTED IMPROVEMENTS}

BEA has worked with J-U-B to evaluate the current wastewater system and to identify future improvements to the facility to provide wastewater service for future growth. This PER summarizes the improvements in accordance with Idaho Administrative Code IDAPA 58.01.16.411. These improvements are part of the MFC West Campus Utility Corridor project and consist of a new gravity collection system, pressurized forcemains, and a lift station. The approximate location of these proposed improvements is shown in Figure 2. Preliminary drawings are also included in Appendix $\mathbf{A}$ of this document. 


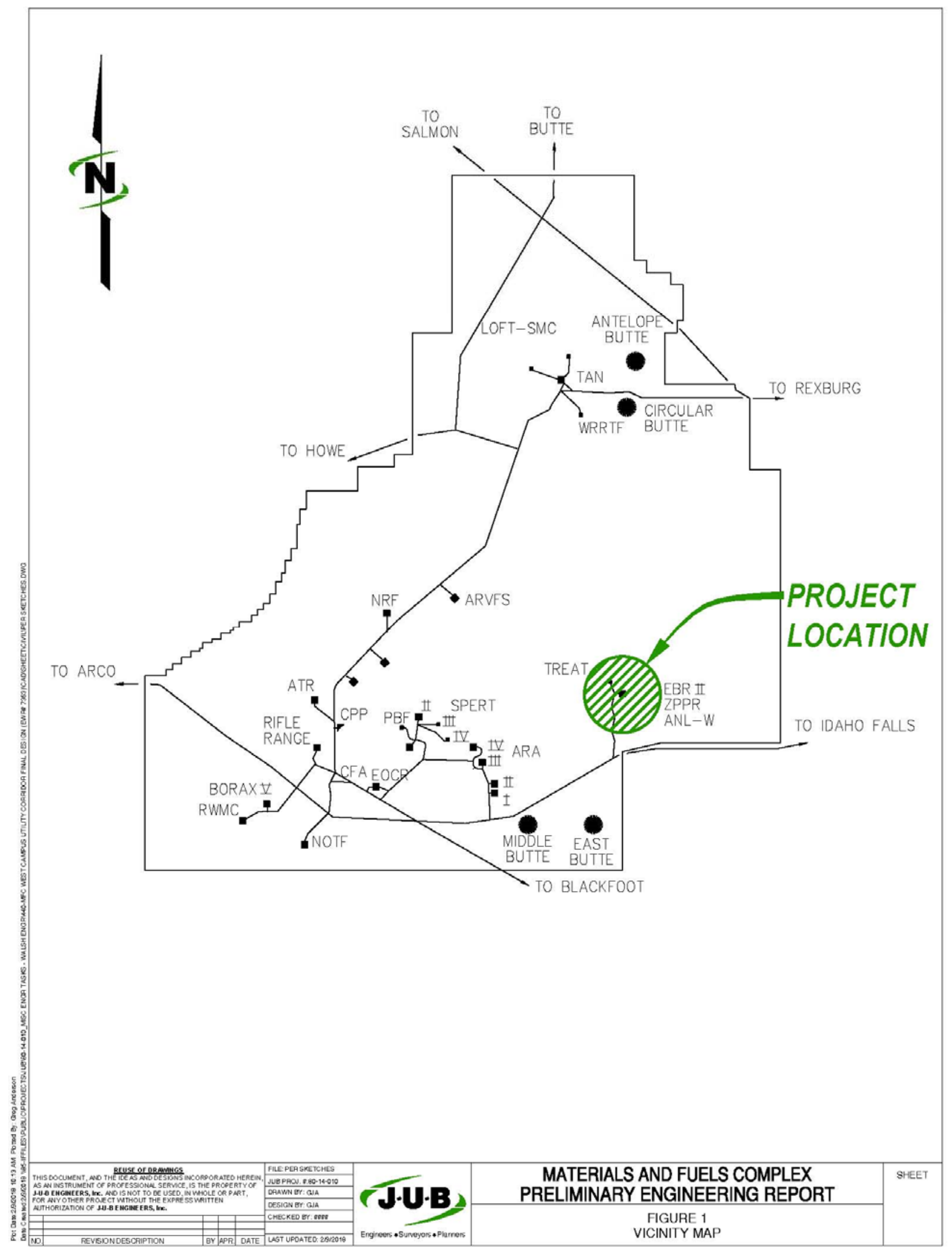

Figure 1 - Vicinity Map 


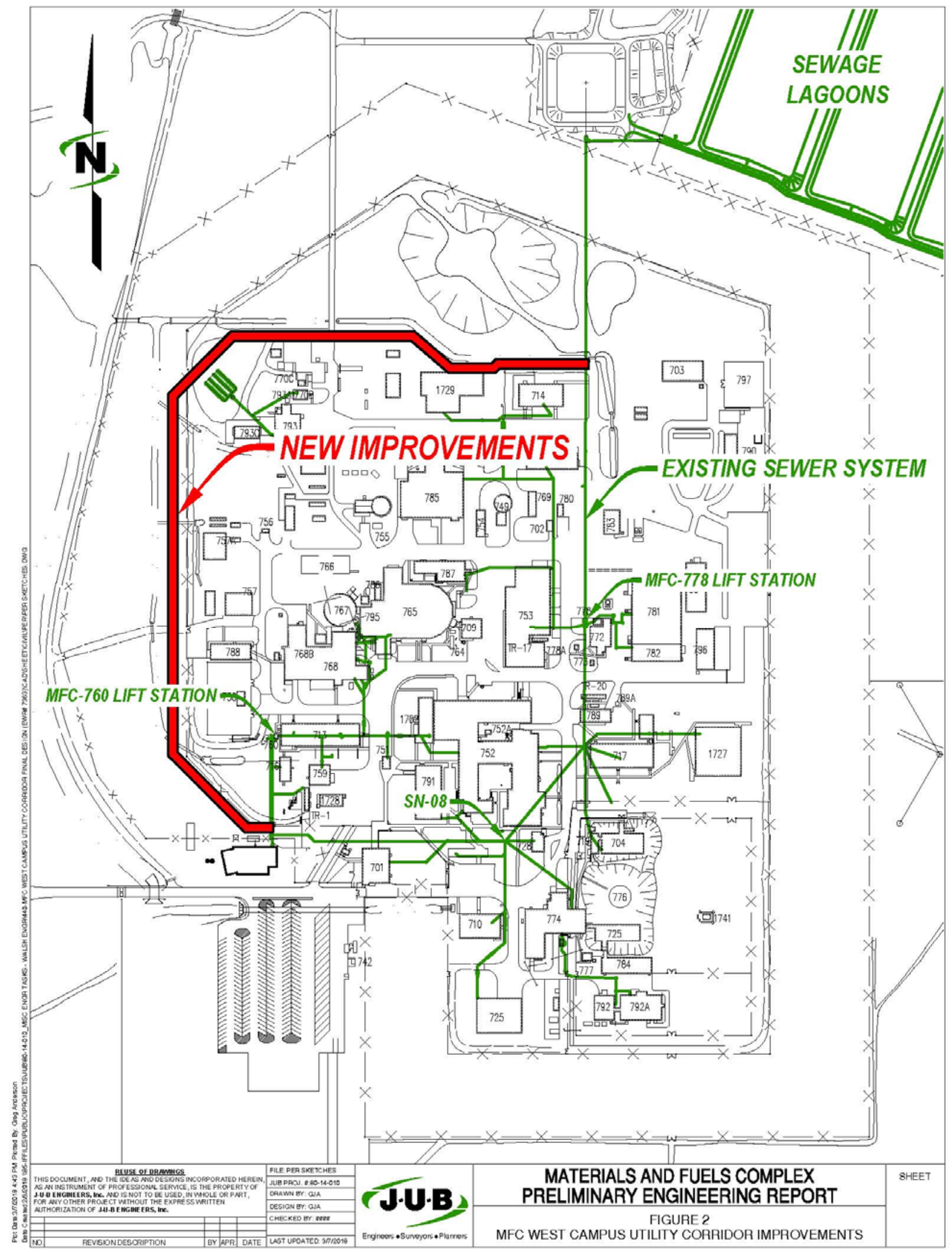

Figure 2 - MFC West Campus Utility Corridor Improvements 


\section{Chapter 2}

\section{Basis of Design}




\section{CHAPTER 2 BASIS OF DESIGN}

\subsection{MFC MASTER PLAN}

The MFC Campus Development Organization (CDO) has developed a Master Plan for future development. The majority of the growth is anticipated to occur on the west and north sides of the MFC Complex. The MFC West Campus Utility Corridor project would provide services (potable/fire water distribution, sanitary sewer, electrical distribution, telecommunications/alarm distribution) to future development on the west and north sides of MFC. Based on the "2017 INL Master Plan", the MFC West Campus Utility Corridor project plans to provide sewer service for approximately 230,000 square feet of new building space and 500 additional people.

\subsection{FUTURE FLOWS AND LOADS}

The area to be served by the new sewer improvements consists of the new area to the west and north identified in the INL Master Plan and described in the previous section of this document. The new sewer improvements will also serve the future Research Collaboration Building (RCB), which is located near the southwest corner of the MFC Complex. In addition, the improvements will accommodate the existing flows from the MFC-760 lift station (see Figure 2 for location). Due to the age and condition of the existing force main from MFC-760 to Manhole SN-08 (cast iron pipe that was installed as early as the 1960s), these flows will be rerouted to the new improvements. The MFC-760 lift station currently services the following facilities:

- Modular Office Buildings T-13 (MFC-713)

- Modular Office Building T-16A (MFC-716)

- Fuel Conditioning Facility (MFC-765)

- Power Plant (MFC-768)

- Emergency Re-Entry Building (MFC-759)

- Safeguards and Security Support Building (MFC-751)

- Portion of the Laboratory and Office Building (MFC-752)

The MFC Wastewater Facility Plan (October 2010) assumed that the average wastewater flow for the MFC Complex is 13 gallons per capita per day (gpcd). It also used a peaking factor to convert the average daily flow to peak flow of 2.5. Using these assumptions, Table 1 summarizes the design flow calculations for the MFC West Campus Utility Corridor project. It should be noted that no industrial waste flows will be routed into the MFC West Campus Utility Corridor project or eventually into the existing lagoons.

Additional capacity for unknowns such as inflow and infiltration $(\mathrm{I} / \mathrm{I})$ will not be considered due to the lack of shallow groundwater at the site and the new condition of the improvements. 
Table 1 - Design Flows

\begin{tabular}{c|c|c|c|c|c}
\hline \hline Description & $\begin{array}{c}\text { Number of } \\
\text { Employees }\end{array}$ & $\begin{array}{c}\text { Average } \\
\text { Daily Flow } \\
\text { (gpd) }\end{array}$ & $\begin{array}{c}\text { Average } \\
\text { Daily Flow } \\
\text { (gpm) }\end{array}$ & $\begin{array}{c}\text { Peaking } \\
\text { Factor }\end{array}$ & $\begin{array}{c}\text { Design Peak } \\
\text { Flow } \\
\text { (gpm) }\end{array}$ \\
\hline Future Growth (West Campus) & $500 \mathrm{~A}$ & 6,500 & 4.51 & 2.5 & 11.28 \\
Research Collaboration Building & $58 \mathrm{~A}$ & 754 & 0.52 & 2.5 & 1.31 \\
MFC-760 Lift Station & - & - & $4.9 \mathrm{~A}$ & 2.5 & 12.25 \\
\hline Totals & & & $\mathbf{9 . 9 4}$ & & $\mathbf{2 4 . 8 4}$ \\
\hline \hline
\end{tabular}

A. Provided by MFC project personnel.

\subsection{DESIGN CONSIDERATIONS}

\subsubsection{Existing Lagoon Capacity}

The existing MFC wastewater lagoons were designed for flows of approximately 14,950 gpd. Based on information provided by MFC staff, in 2017, the average daily flow to the lagoons was approximately 7,840 gpd. Based on Table 1, the MFC West Campus future projects will produce an average daily flow of 7,254 gpd for a total flow of 15,094 gpd. This is just slightly above the design flows for the existing lagoons (less than 1\%). The MFC West Campus future projects are based on a 23-year buildout (2017-2030) and the existing lagoons, built in 2012, were based on a buildout to the year 2020. Hence, the lagoons appear to have adequate capacity for the MFC West Campus future projects.

\subsubsection{Geotechnical Investigation}

A geotechnical investigation was completed by Materials Testing and Inspection (MTI). The investigation included 15 borings along the alignment of the MFC West Campus Utility Corridor project as well as 28 additional borings located near the future project site for the Sample Preparation Laboratory (SPL) not associated with this project. However, the geotechnical information gathered for the SPL will be used for the MFC West Campus Utility Corridor project. This geotechnical engineering evaluation is included in Appendix B, which includes a detailed description of the evaluation along with recommendations.

In general, poorly graded gravel with silt and sand fill materials were encountered at the ground surface. These fill materials were brownish gray, slightly moist to moist, and medium dense to dense, with fine to coarse-grained sand and 2-inch minus gravel. Varying silt-clay-sand mixtures were encountered beneath fill materials. These soils were brown, slightly moist to moist, and soft to very stiff, with fine-grained sand. Intermittent gravel content was noted within the deeper portions of these horizons.

Basalt bedrock was encountered in many of the borings with depths varying from 1.3 to over 14 feet below the ground surface along with proposed alignment. It is anticipated that rock removal techniques will be employed to install the new lift station, manholes, gravity and pressure pipelines (e.g., rock trencher, rock hammer, etc.). No explosives or blasting will be allowed.

Groundwater was not encountered during the geotechnical investigation and is not anticipated during construction.

It is anticipated that site soils will generally be used for trench backfill above the pipe bedding; although, import trench backfill material may be required in areas where unsuitable soils are excavated. 


\subsubsection{Environmental Considerations}

An Environmental Checklist is currently being developed by BEA project personnel and is planned to be completed by the completion of final design. The National Environmental Policy Act (NEPA) review process will consider the utility corridor's impact to nearby Comprehensive Environmental Response, Compensation, and Liability Act (CERCLA) areas, the industrial wastewater piping and industrial waste ditch regulated by Idaho Department of Environmental Quality Reuse Permit I-160-02, Modification 1, and storm water ditches, as well as other environmental aspects affected. The new utility corridor will also cross two existing permitted industrial waste water lines. These existing lines will be retained and protected during construction as required by the permit.

\subsubsection{Safety Considerations}

The MFC West Campus Utility Corridor project has the potential to impact the Irradiated Materials Characterization Laboratory (IMCL) nuclear facility located at the northern portion of the MFC Complex. Excavation of trenches on the north side of $I M C L$ will need to be evaluated to ensure that the integrity of the structure and footings is not compromised.

There are no special considerations with construction safety beyond the normal OSHA-controlled aspects.

\subsubsection{Security and Safeguards Considerations}

The MFC West Campus Utility Corridor project lies within the existing security perimeter area enclosed by two security fences. Equipment and infrastructure installed between the security fences in the isolation zone will be installed below grade or no more than 4 inches above grade to ensure security equipment operates properly.

During construction, some equipment may remain within the security area, but mobile equipment must be moved out of the area each night. The construction area will be bounded by additional fencing on the north and south to enclose it within the security area. Compensatory measures may be required in areas where the trench will cross the fence.

After construction and during operation of the new improvements, access to the lift stations, manholes, and other appurtenances will be by authorized personnel only.

\subsubsection{Operations and Maintenance}

BEA oversees the maintenance and operations of the wastewater collection and treatment systems at the MFC Complex. An operations and maintenance manual will be prepared at the completion of the project which will identify specific operation and maintenance tasks. In general, the operation and maintenance of the facility will be similar to that of the other submersible lift stations, pressurized, and gravity sewer pipelines located in the MFC Complex.

\subsubsection{Applicable Standards, Codes, and Permits}

Following are the anticipated standards, codes, and permits that are applicable to the wastewater portion of the project:

- 2017 Idaho Standards for Public Works Construction (ISPWC)

- Project-specific Specifications 
- Idaho Administrative Code IDAPA 58.01.16 Wastewater Rules

- Idaho National Laboratory STD-139 INL Engineering Standards

- 10 States Standards Recommended Standards for Wastewater Facilities

- LWP-13014 Determining Quality Levels

- LWP-10500 Configuration Information Management

- 2014 National Electric Code (with Idaho State amendments)

- 2009 Idaho State Plumbing Code (with 2014 updates) 
This page is left intentionally blank

Materials and Fuels Complex

West Campus Utility Corridor PER 


\section{Chapter 3}

\section{Preliminary Design}




\section{CHAPTER 3 PRELIMINARY DESIGN}

\subsection{PRESSURE AND GRAVITY SEWER MAINS}

\subsubsection{Description and Layout}

Appendix A includes preliminary drawings that illustrate the proposed alignment of the new pressure and gravity sewer mains. The alignment begins with the new pressure main connecting into the existing MFC760 force main located directly north of the future RCB. This new force main will run in a westerly direction and then to the north between the perimeter security fences where it will discharge into a new manhole located directly west of MFC-788. From this point, a new gravity sewer line will run parallel with the existing security fence until it discharges into a new lift station located north of SPL. The new lift station will convey the wastewater through a new pressure main and connect into the existing force main.

The gravity sewer mains will consist of 8-inch diameter pipe constructed of ASTM D-3034 SDR 35 PVC sewer pipe. Standard pre-cast manholes will be used at every change in direction and spaced a minimum 400 feet.

The pressure sewer mains will consist of 4-inch diameter pressure class pipe constructed of C-900 PVC or C-906 HDPE. Pressure clean-outs have also been installed on the pressure main to permit flushing of the line, if necessary.

\subsubsection{Pipe Depth}

In general, the pressurized mains will be buried below anticipated frost penetration which is 5 feet per INL-STD-139. However, due to conflicts with other buried utilities and/or rock, the pressure main may be installed at greater or lesser depths to avoid conflicts and crossings. In the event that the mains are installed at depths less than 5 feet below the ground surface, measures to ensure the pipe does not freeze will be necessary such as insulation and/or heat trace cabling. It is anticipated that the design of the pressure main will be such that there is a positive grade from the lift station to the tie-in points so that no air release valves will be needed.

It is generally anticipated that the gravity sewer mains will be installed with cover depths ranging from 512 feet below the ground surface. Rock excavation will be necessary in some areas due to the shallow depths encountered during the geotechnical investigation.

\subsubsection{Utilities Crossing Considerations}

There are numerous existing utilities that will be crossed by the new sewer alignment. Existing underground utilities along the proposed sewer main alignment have been located via a subsurface investigation performed by BEA. The marked locations of these underground utilities, as well as above ground utilities and surface features, were surveyed and will be identified on the final construction drawings. Known utilities that will be crossed are potable water, storm drain, industrial waste, electrical/communication conduits and ductbanks, and power poles.

All potable water crossings will be designed in accordance with IDAPA 58.01.16.430.02. Other than potential crossing conflicts, no other impacts to the drinking water system at MFC are anticipated. 
It is anticipated that all other crossings will be constructed without disturbing the existing utilities. If existing utilities are disturbed, they will be replaced and reinstalled to their original condition.

\subsubsection{Preliminary Design Criteria}

Table 2 summarizes the preliminary design criteria for the gravity collection system improvements. Preliminary design calculations can be found in Appendix C. As shown in the table, the gravity pipeline sizes and slopes are adequate to convey the proposed peak hour flows.

Table 3 summarizes the preliminary design criteria for the new pressure sewer main. The velocity in the pressure main at the design pumping rate for the lift station (i.e., $120 \mathrm{gpm}$ ) is approximately 3 feet per second (fps). This velocity is greater than the minimum regulatory requirement of 2 fps (IDAPA 58.01.16.44.10.a).

Table 2 - Gravity Collection System Preliminary Design Criteria

\begin{tabular}{c|c|c|c|c|c|c|c|c|c}
\hline \hline $\begin{array}{c}\text { Pipe } \\
\text { Segment }\end{array}$ & $\begin{array}{c}\text { Pipe } \\
\text { Material A }\end{array}$ & $\begin{array}{c}\text { Pipe } \\
\text { Size } \\
\text { (in) }\end{array}$ & $\begin{array}{c}\text { Pipe } \\
\text { Length }\end{array}$ & $\begin{array}{c}\text { Pipe } \\
\text { Slope } \\
\text { (\%) }\end{array}$ & $\begin{array}{c}\text { Capacity at } \\
75 \% \text { Full } \\
\text { (gpm) }\end{array}$ & $\begin{array}{c}\text { Adequate } \\
\text { Peak Hour } \\
\text { Flow? B }\end{array}$ & $\begin{array}{c}\text { Approx } \\
\text { Pipe Bury } \\
\text { Depth } \\
\text { (ft) }\end{array}$ & $\begin{array}{c}\text { Depth to } \\
\text { Rock } \\
\text { from } \\
\text { Pipe } \\
\text { Invert } \\
\text { (ft) }\end{array}$ & Installation Method \\
\hline MH 1 to MH 2 & PVC & 8 & 400 & 0.40 & 330 & Yes & $5-6$ & $0-1$ & $\begin{array}{c}\text { Open Trench/Rock } \\
\text { Trencher }\end{array}$ \\
\hline MH 2 to MH 3 & PVC & 8 & 240 & 0.40 & 330 & Yes & $6-8$ & $0-5$ & $\begin{array}{c}\text { Open Trench/Rock } \\
\text { Trencher }\end{array}$ \\
\hline MH 3 to MH 4 & PVC & 8 & 203 & 0.40 & 330 & Yes & $8-11$ & $2-5$ & Open Trench \\
\hline MH 4 to LS & PVC & 8 & 400 & 0.40 & 330 & Yes & $9-10$ & $1-3$ & Open Trench \\
\hline \hline
\end{tabular}

A. PVC pipe conforming to ASTM D3034

B. Peak hour flow $=25 \mathrm{gpm}$

Table 3 - Pressure Sewer Main Preliminary Design Criteria

\begin{tabular}{c|c}
\hline \hline Parameter & Value \\
\hline Pipe Material & PVC (ASTM D2241) \\
\hline Pipe Size & 4 inch \\
\hline Pipe Slope & Varies (positive grade) \\
\hline Minimum Bury Depth & 5 feet \\
\hline Minimum Velocity at Design Pumping Rate & $3.0 \mathrm{fps}$ \\
\hline \hline
\end{tabular}

\subsubsection{Corrosion Protection}

Corrosion within the sewer pipelines will be mitigated via construction materials. All new sewer mains will be constructed of corrosion resistant materials (PVC, HDPE). MFC project personnel have stated that corrosion of their concrete manholes has historically not been an issue. 


\subsubsection{Odor Control}

Odor has generally not been a concern for the wastewater system at the MFC Complex. As a result, odor is not anticipated to be an issue and mitigation strategies are not included in this PER or final design of the proposed improvements. If odors become an issue, MFC may need to revisit them in the future.

\subsection{LIFT STATION}

\subsubsection{Description and Layout}

As shown in the preliminary drawings included in Appendix A, the new lift station will be located directly north of the IMCL building. The lift station will be located within the perimeter security fence, which is monitored by MFC security personnel at all times. The lift station will receive wastewater from the new 8-inch gravity sewer main and discharge it through a single 4-inch pressure main that will connect to an existing 4-inch pressure main, eventually conveying the wastewater to the treatment lagoons.

The lift station will consist of a wet-well mounted pumping station with duplex, submersible, non-clog pumps and a concrete wet-well structure. The pumps will alternate on pumping cycles to provide even wear. Each pump will be capable of handling the ordinary peak flows, which will provide redundancy and allow maintenance of one pump and still leave the lift station in service. A high level float switch will turn on both pumps to provide for extra large peak flows which may occur at infrequent intervals. The pumps will be grinder pumps which will grind the sewage into a slurry and pump to a pressurized sewer main.

A back-up portable diesel generator and automatic transfer switch will be available near the lift station to provide auxiliary power in the event of an outage. The electrical and control panels will be located on a free-standing equipment rack near the lift station. Alarm outputs will be included in the control panel and will include power failure, pump failure, high water level, and low water level alarms. Each of these alarm signals will be sent to a local alarm and light at the lift station to inform the maintenance staff of the status of the lift station.

Since the new lift station and new collection system will be capable of serving a much larger service area than what will be originally required, the wastewater will be stored in the lift station wet well during initial operation for an extended period of time until the wastewater level rises high enough to start a pump. This extended storage time in the lift station may result in odor issue as well as other maintenance issues. For these reasons, carbon filters on the wet well vents will be installed to mitigate odor problems. During initial operation with low flows, the pump ON/OFF level set-points should be tightened as much as possible to minimize the operating volumes and cycle times. However, a minimum operating volume should be maintained to provide reliable level control and avoid cycling of the pumps in excess of the manufacturer's recommendations (typically less than 8 to 10 starts per hour). Also, it may be necessary to supplement the wastewater flow with additional clean water to keep the pumps cycling more often (e.g. 2-3 times per day) since the initial flows will be lower than designed for. Any infrastructure to add clean water will need to comply with cross-connection control regulations with approved backflow prevention measures.

\subsubsection{Preliminary Design Criteria}

Table 4 summarizes the preliminary design criteria for the lift station. Preliminary design calculations can be found in Appendix C. 
Table 4 - Lift Station Preliminary Design Criteria

\begin{tabular}{lc}
\multicolumn{1}{c}{ Parameter } & Preliminary Design Value \\
\hline \hline Design Peak Hour Flow & $25 \mathrm{gpm}$ \\
\hline Configuration & Wet-Well Mounted, Duplex, Submersible, Non-Clog Pumps \\
\hline Number of Pumps & 2 \\
\hline Motor Horsepower per Pump & $1.5 \mathrm{Hp}$ \\
\hline Flow per Pump & $120 \mathrm{gpm}$ \\
\hline Head/TDH per Pump & $16 \mathrm{ft} \pm$ \\
\hline Nominal Pump Speed & 1150 rpm (Constant Speed) \\
\hline Wet-Well & 60-inch Diameter x 18.5 feet Deep, Precast Concrete Structure \\
\hline Flow Meter Vault & 4' Diameter x 6' Deep, Precast Concrete Structure \\
\hline Flow Measurement & 6" Magnetic Flow Meter \\
\hline Level Controls/lnstrumentation & Ultrasonic Level Transducer, \\
\hline Alarms & Float Switches for High and Low Water Levels \\
\hline \hline
\end{tabular}

\subsubsection{Flow Measurement}

Flow measurement will consist of a magnetic flow meter located on the force main within a vault directly downstream of the wet well and valve vault. The flow meter transmitter will be placed on the electrical panel. The flow meter will measure the flow from the new lift station.

\subsubsection{Controls and Operation}

The lift station will include an ultrasonic level or pressure transducer and two back-up float switches. Primary control of the pumps will be from the transducer device based on water levels in the wet-well. As water levels rise in the wet-well to a set-point, the lead pump will be turned on. Under normal conditions, the lead pump will draw the water level down to a low water level set-point and turn off. If the lead pump is unable to keep up with influent flows and water levels continues to rise, the second (lag) pump will be turned on to draw water levels down to the shut-off set point. This cycle will be repeated with the pumps alternating in the lead/lag position.

Back-up float switches will be used to alarm the operator if the water level rises above a high water level set-point or decreases below a low water level set-point in the wet-well. The pump will also be shut-off in a low water level condition to prevent overheating.

The electrical and control panels will be located on a free-standing equipment rack beneath a shade structure. The operator will be able to control the pumps in automatic and manual mode from a local control panel. Since the MFC Complex does not have a Supervisory Control and Data Acquisition (SCADA) system, alarms will be distributed from the control panels through an autodialer. An automatic transfer switch will turn on the generator to power the lift station in the event of a power outage.

\subsubsection{Buoyancy Considerations}

Groundwater was not encountered in any of the rock borings near the lift station site. As a result, structure buoyancy should not be a concern. 


\subsubsection{Flooding Potential}

The finished top of slab elevations for the wet-well and flow meter vault will be approximately 3 inches above the finished ground to prevent any run-off from entering the structures. The area surrounding the structures will be graded to drain away from them. The site is not located within a designated flood plain and MFC has stated that flooding has not historically been an issue at the site.

\subsubsection{Odor Potential}

Since the new lift station will be situated in a relatively remote location and near the treatment lagoons, it is anticipated that there will be negligible additional odors after construction of the new lift station. Additionally, the operating volume in the lift station wet-well will be set such that the retention time of the wastewater is minimized. This will reduce the potential for anaerobic conditions and the generation of odors.

\subsubsection{Consideration of Future Expansion}

The wet-well will be sized to accommodate future larger pumps and to provide sufficient operating volume for the build-out flows. The flow meter will be sized to measure the build-out flows, as well.

\subsection{EXISTING MFC-760 LIFT STATION}

The MFC-760 lift station and a portion of the existing 4-inch diameter force main (approximately 250 linear feet) will remain and a new 4-inch diameter force main will be connected as described in Chapter 2 of this PER. The lift station originally had sewage pumps designed for $70 \mathrm{gpm}$ at 18 feet of TDH. In 2001, these pumps were replaced with Goulds Model 3888D4M pumps which appear to be capable of similar performance as the original pumps. This indicates that the existing lift station should have ample capacity to accommodate the existing flows, as well as the additional flows from the RCB. 


\section{Chapter 4}

\section{Project Costs and Schedule}




\section{CHAPTER 4 PROJECT COSTS AND SCHEDULE}

\subsection{COST SUMMARY}

An opinion of probable construction costs in 2018 dollars for the MFC West Campus Utility Corridor project improvements is summarized in Table 5. The project will be funded through the Department of Energy.

Table 5 - Opinion of Probable Construction Costs

\begin{tabular}{|c|c|c|}
\hline Item & \multicolumn{2}{|c|}{ Total Cost } \\
\hline General Requirements/Mobilization/Demobilization & \multicolumn{2}{|c|}{$\$ 189,900$} \\
\hline Lift Station & \multicolumn{2}{|c|}{$\$ 1,350,900$} \\
\hline Collection System Improvements & \multicolumn{2}{|c|}{$\$ 494,400$} \\
\hline Stormwater Management & \multicolumn{2}{|c|}{$\$ 87,300$} \\
\hline Sub-Total Construction Costs & \multicolumn{2}{|c|}{$\$ 2,122,500$} \\
\hline Contingency (20\%) & \multicolumn{2}{|c|}{$\$ 424,500$} \\
\hline Total Construction Costs & \multicolumn{2}{|c|}{$\$ 2,547,000$} \\
\hline $\begin{aligned} \text { A. } & \text { Costs do not include BEA oversight, procurement, } \\
\text { B. Costs do not include fire water, electrical, or comm } & \\
\text { 4.2 } & \text { PROJECT SCHEDULE }\end{aligned}$ & \multicolumn{2}{|c|}{$\begin{array}{l}\text { Costs do not include BEA oversight, procurement, environmental, safety, or engineering } \\
\text { Costs do not include fire water, electrical, or communication improvements }\end{array}$} \\
\hline \multicolumn{3}{|c|}{ Table 6 summarizes the preliminary project schedule for the MFC West Campus Utility Corridor projec } \\
\hline Task & Start Date & End Date \\
\hline Conceptual Design & November 2017 & January 2018 \\
\hline Final Design & January 2018 & April 2018 \\
\hline Bid and Award & April 2018 & July 2018 \\
\hline Construction & July 2018 & September 2019 \\
\hline
\end{tabular}


Appendix A

Preliminary Design Drawings 



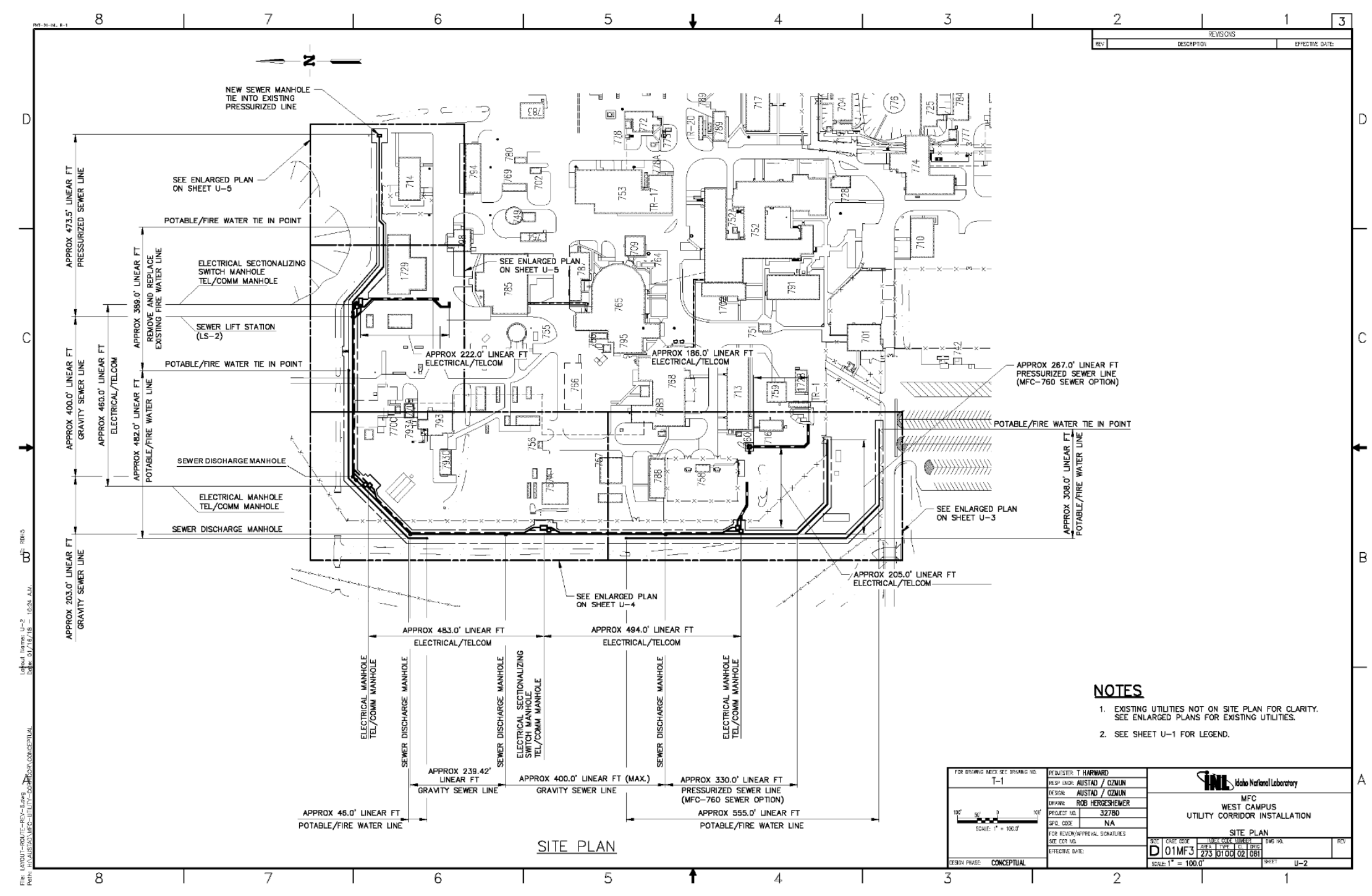




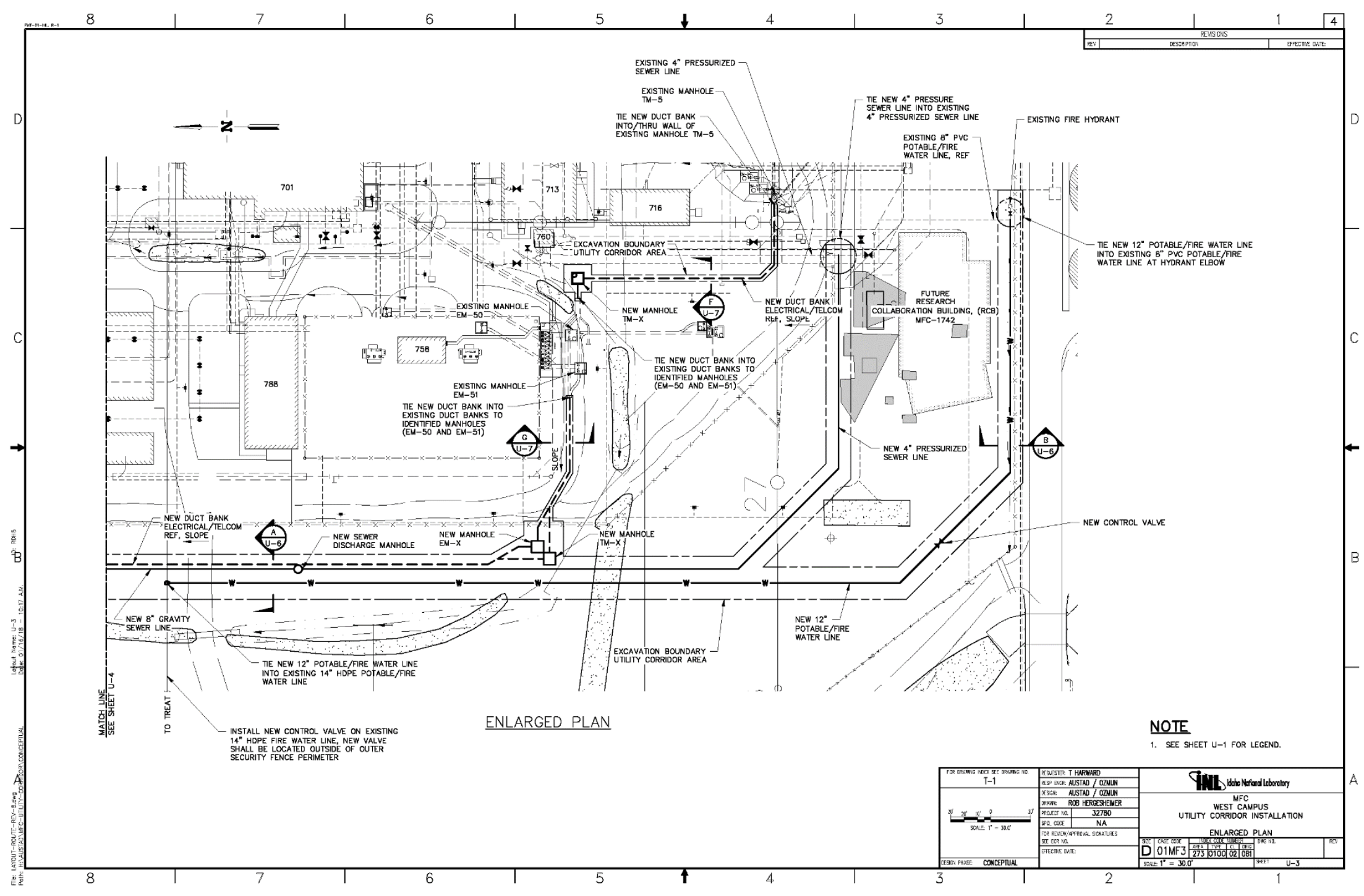




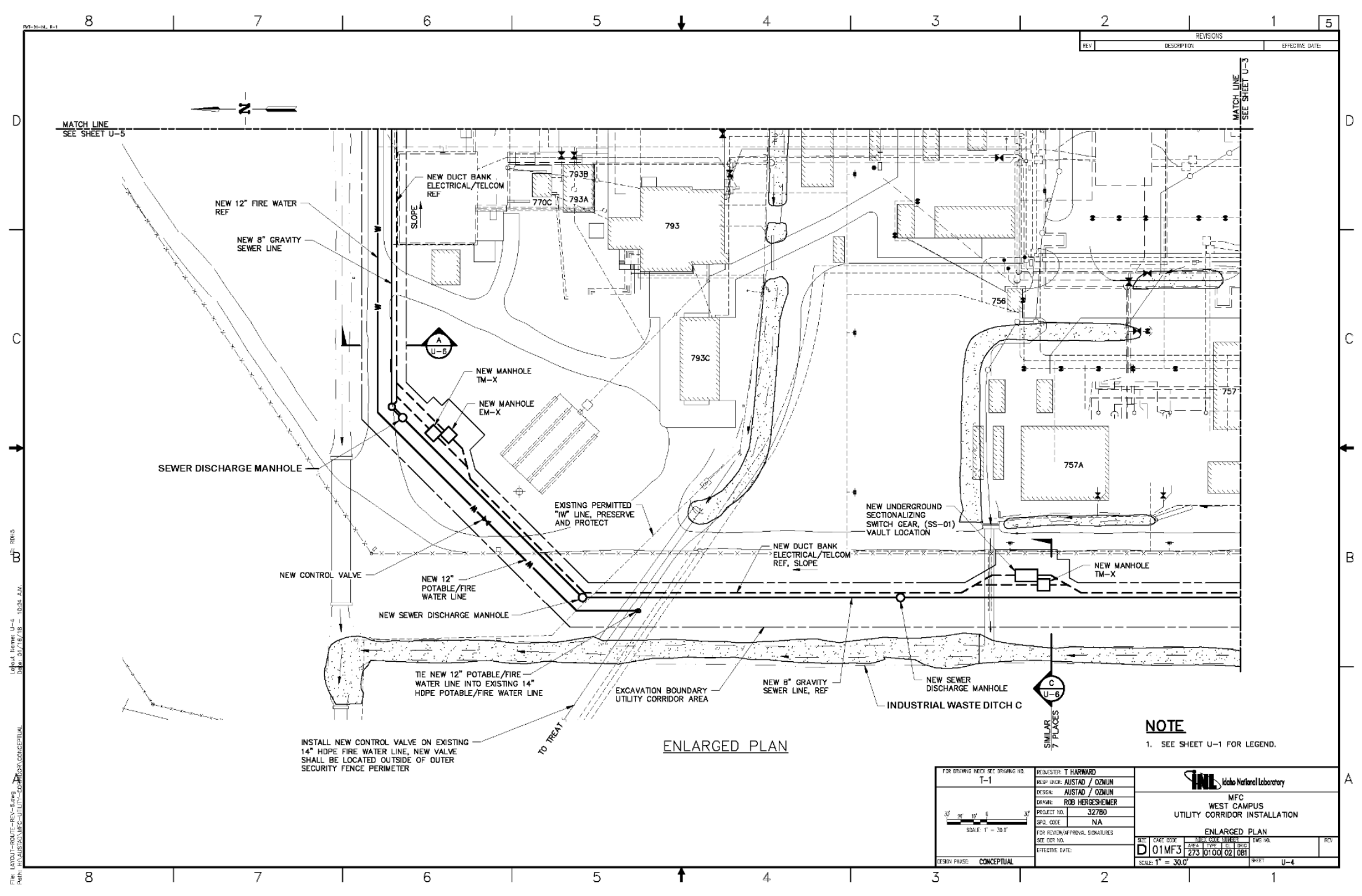




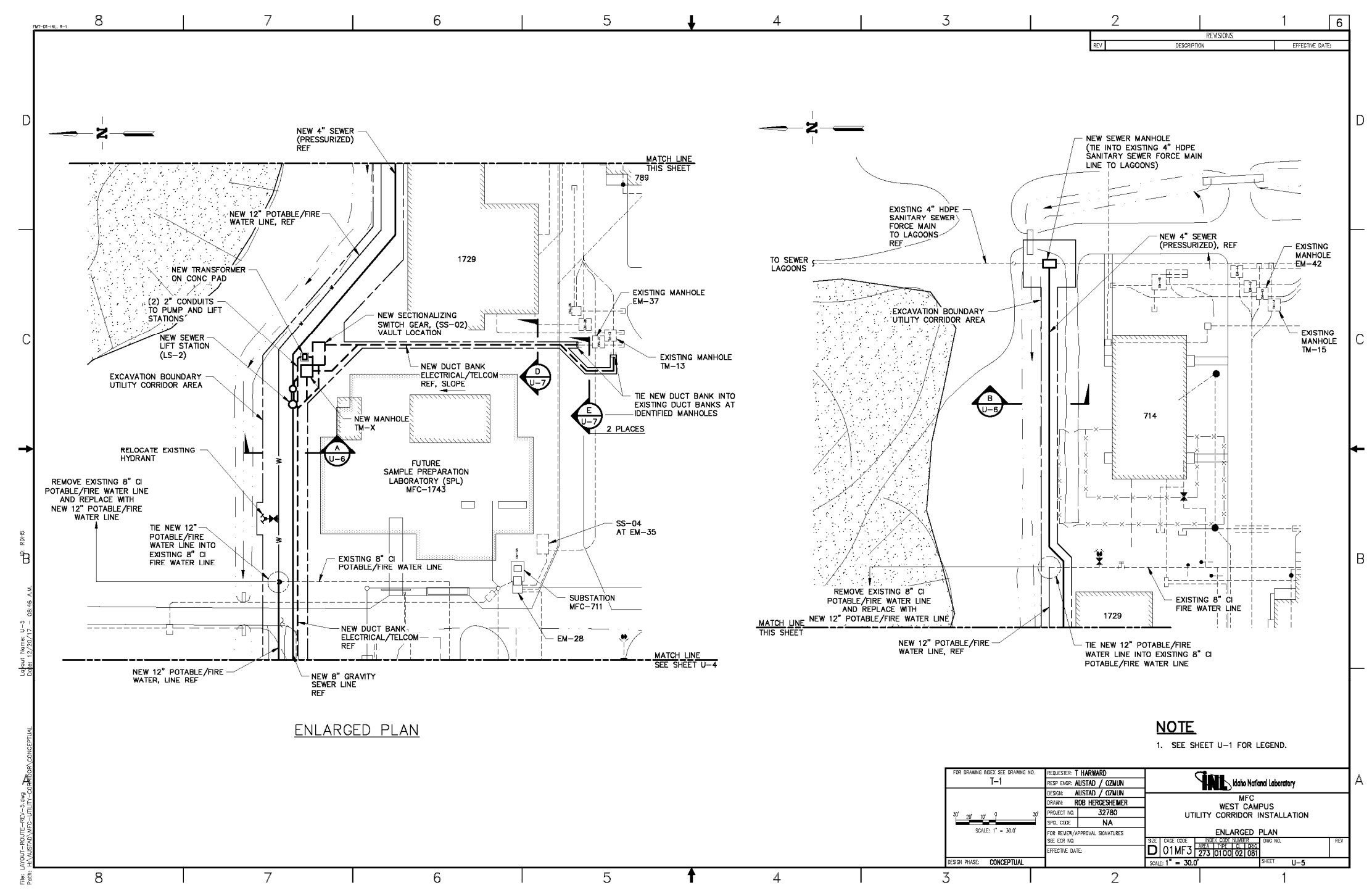


Appendix B

Geotechnical Report 
MATERIALS

TESTING E

INSPECTION

DEnvironmental Services

\section{Geotechinical Engineering RePORT \\ of \\ Sample Preparation Laboratory \\ INL Materlals \& Fuel Complex \\ Bingham County, ID}

Prepared for:

Battelle Energy Allance, LLC

2525 fremont Avenue, PO Box I625

Idaho Falls, ID 83415

MTI File Number EI7O2B3g

Contract 19433!

1230 N Skyline Drive, Suite C • Idaho Falls, ID 83402 • (208) 529-8242 • Fax (208) 529-6911 
Ms. Elise Miller

Battelle Energy Alliance, LLC

2525 Fremont Avenue, PO Box 1625

Idaho Falls, ID 83415

208-526-2196

\section{Re: Geotechnical Engineering Report Sample Preparation Laboratory INL Materials \& Fuel Complex Bingham County, ID}

Dear Ms. Miller:

In compliance with your instructions, MTI has conducted a soils exploration and foundation evaluation for the above referenced development. Fieldwork for this investigation was conducted from 11 to 19 January 2018. Data have been analyzed to evaluate pertinent geotechnical conditions. Results of this investigation, together with our recommendations, are to be found in the following report. We have provided a PDF copy for your review and distribution.

Often, questions arise concerning soil conditions because of design and construction details that occur on a project. MTI would be pleased to continue our role as geotechnical engineers during project implementation. Additionally, MTI can provide materials testing and special inspection services during construction of this project. If you will advise us of the appropriate time to discuss these engineering services, we will meet with you at your convenience.

MTI appreciates this opportunity to be of service to you and looks forward to working with you in the future. If you have questions, please call (208) 529-8242.

Respectfully Submitted,

Materials Testing \& Inspection

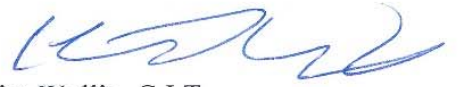

Clint Wyllie, G.I.T.

Staff Geologist

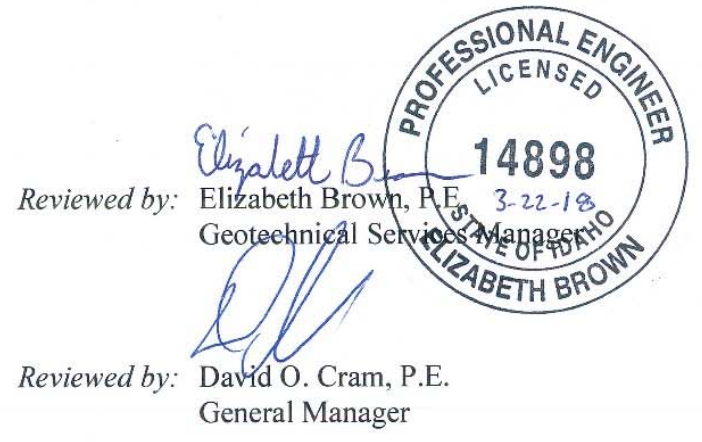




\section{TABLE OF CONTENTS}

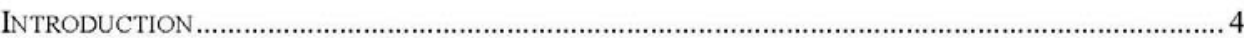

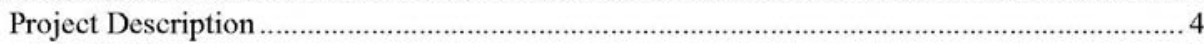

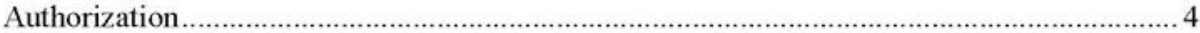

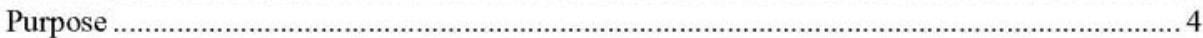

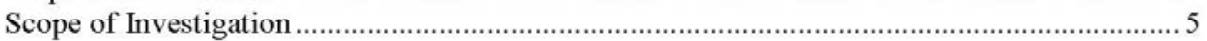

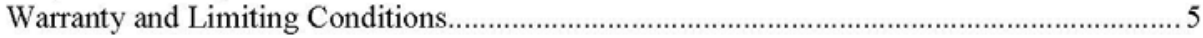

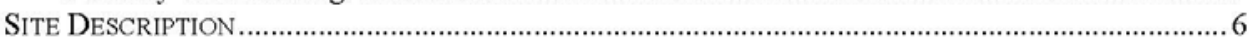

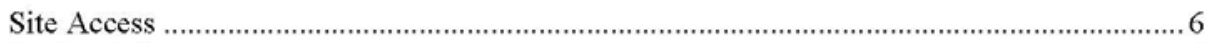

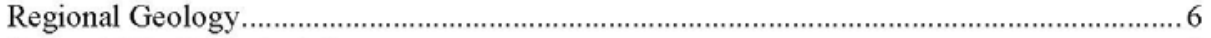

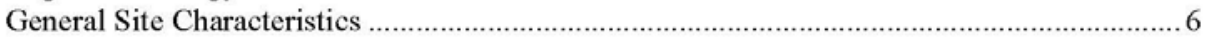

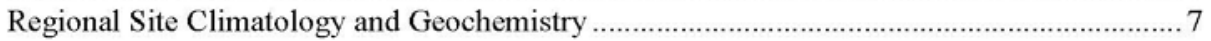

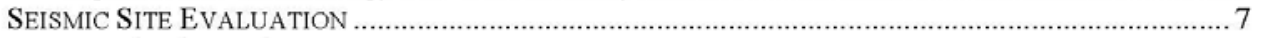

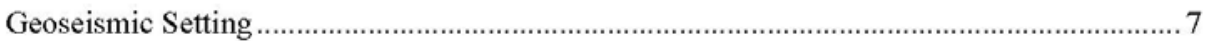

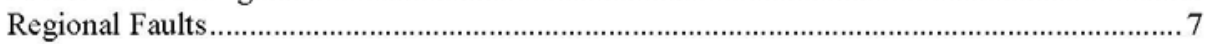

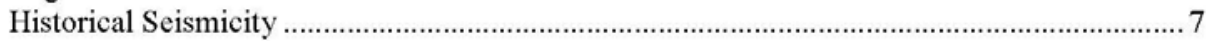

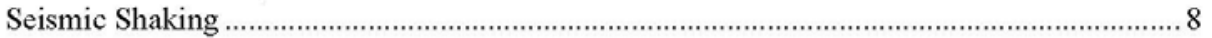

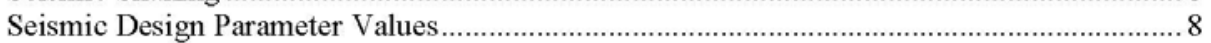

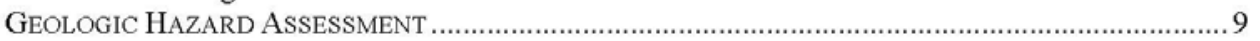

Seismically Induced Surface Rupture, Settlements, and I ateral Spreading ...................... 9

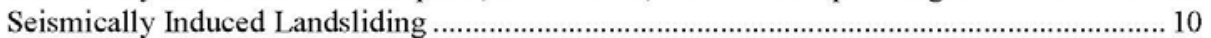

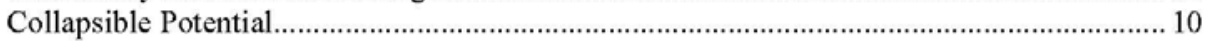

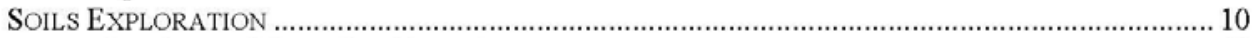

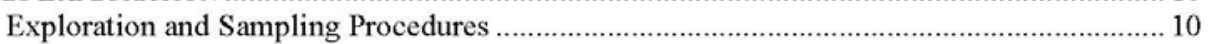

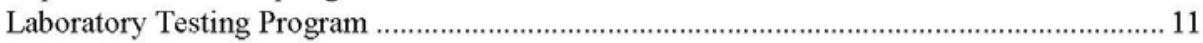

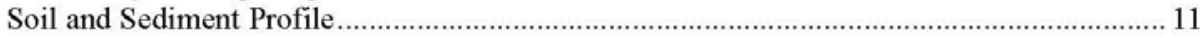

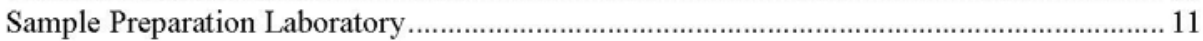

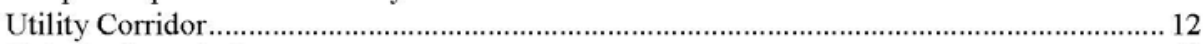

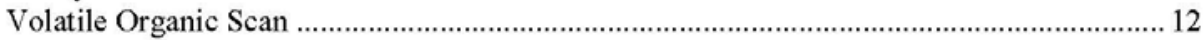

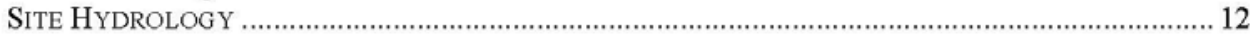

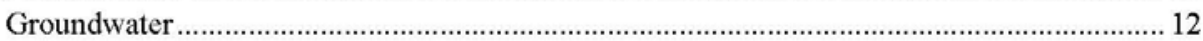

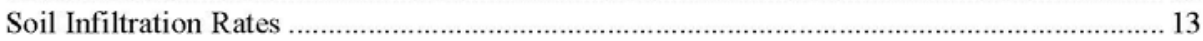

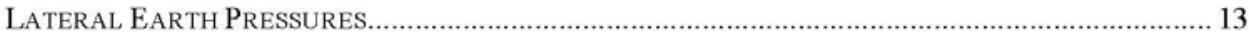

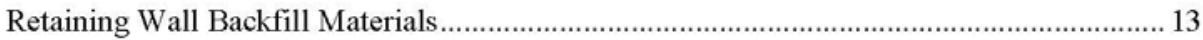

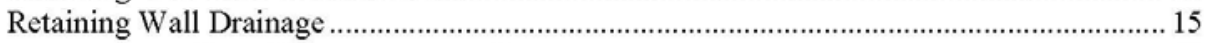

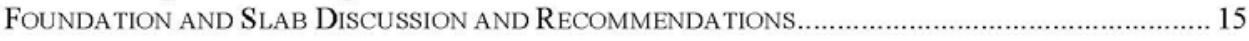

Foundation Design Recommendations ................................................................... 16

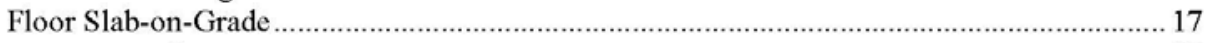

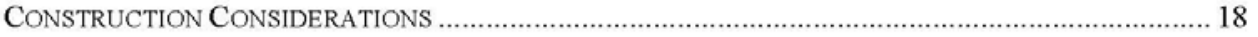

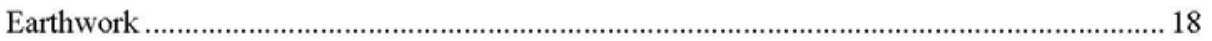

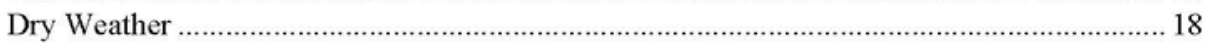

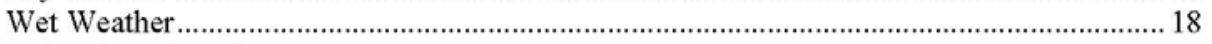

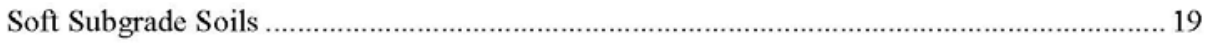




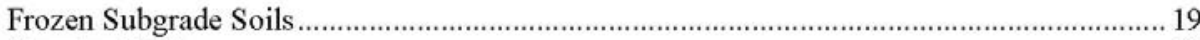

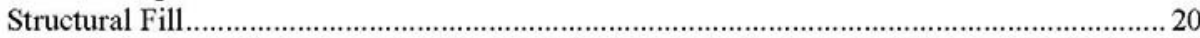

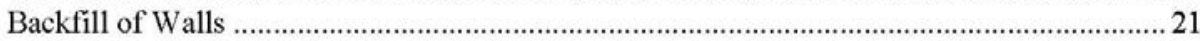

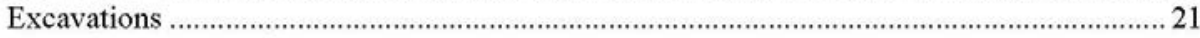

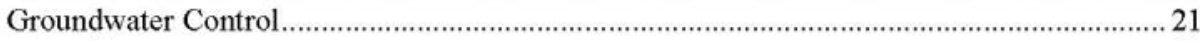

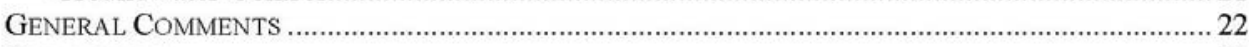

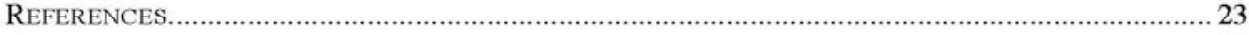

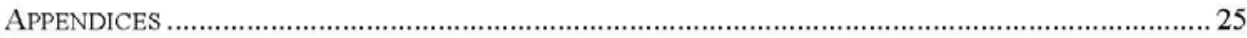

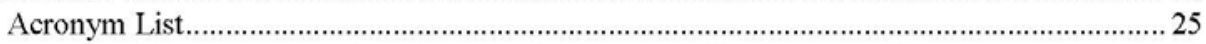

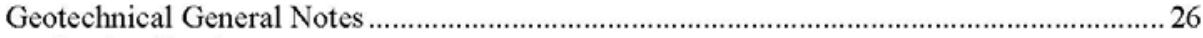

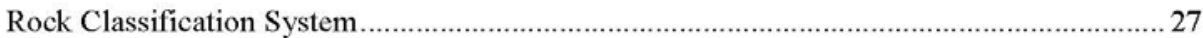

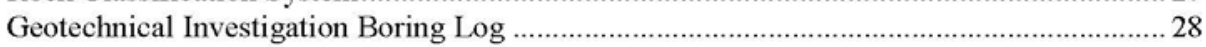

Utility Corridor Soil Probe Depth to Bedrock.................................................................. 58

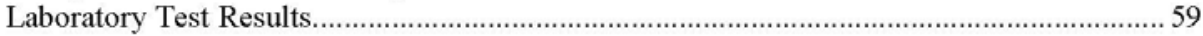

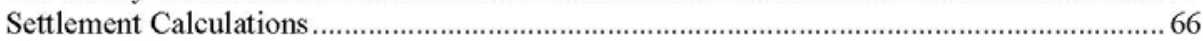

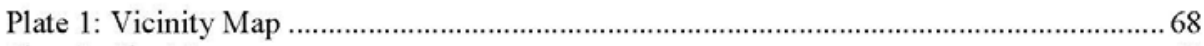

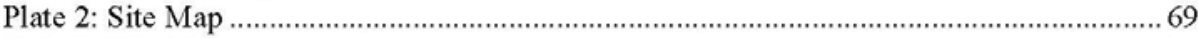

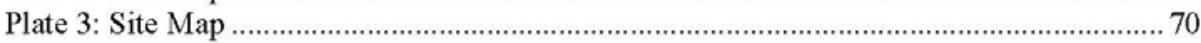

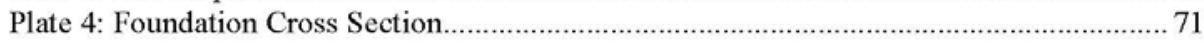

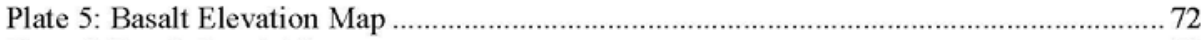

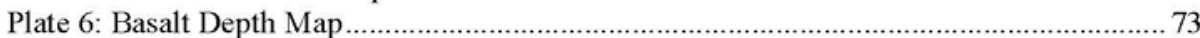

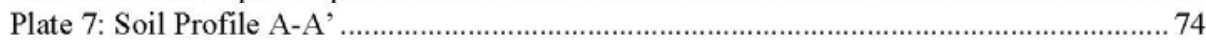

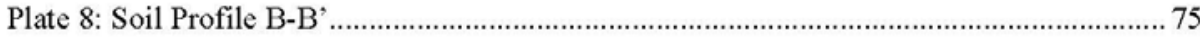




\section{INTRODUCTION}

This report presents results of a geotechnical investigation and analysis in support of data utilized in design of structures as defined in the 2015 International Building Code (IBC). Information in support of groundwater and stormwater issues pertinent to the practice of Civil Engineering is included. Observations and recommendations relevant to the earthwork phase of the project are also presented. Revisions in plans or drawings for the proposed development from those enumerated in this report should be brought to the attention of the soils engineer to determine whether changes in the provided recommendations are required. Deviations from noted subsurface conditions, if encountered during construction, should also be brought to the attention of the soils engineer.

\section{Project Description}

The proposed development is in the northern portion of Bingham County, ID, and occupies a portion of the $\mathrm{NW}^{1 / 4 \mathrm{NW}^{1 / 4}}$ of Section 13, Township 3 North, Range 32 East, Boise Meridian. This project will consist of construction of a 14,884 square-foot, three-story office building with a centrally located two-story, shielded hot cell. The hot cell will be constructed with 4 -foot thick reinforced concrete walls. An overhead crane will operate inside of the structure. Additionally, an approximately 1,400 linear-foot utility corridor will be constructed to service the new structure.

The scope of work for the project indicated that the maximum tolerable differential settlement for the structure is $1 / 4$-inch. MTI was informed by Walsh Engineering that the structure was being designed for an allowable soil bearing pressure of 2,500 pounds per square foot (psf).

\section{Authorization}

Authorization to perform this exploration and analysis was given in the form of a written authorization to proceed from Ms. Elise Miller of Battelle Energy Alliance, LLC to M. Brad Tanberg of Materials Testing and Inspection (MTI), on 20 November 2018. Said authorization is subject to terms, conditions, and limitations described in the Professional Services Contract entered into between Battelle Energy Alliance, LLC and MTI.

\section{Purpose}

The purpose of this Geotechnical Engineering Report is to determine various soil profile components and their engineering characteristics for use by either design engineers or architects in:

- Preparing or verifying suitability of foundation design and placement

- Preparing site drainage designs

- Indicating issues pertaining to earthwork construction 


\section{MATERIALS}

\section{Scope of Investigation}

The scope of this investigation included review of geologic literature and existing available geotechnical studies of the area, visual site reconnaissance of the immediate site, subsurface exploration of the site, field and laboratory testing of materials collected, and engineering analysis and evaluation of foundation materials. Our scope of work did not include pavement design recommendations.

\section{Warranty and Limiting Conditions}

MTI warrants that findings and conclusions contained herein have been formulated in accordance with generally accepted professional engineering practice in the fields of foundation engineering, soil mechanics, and engineering geology only for the site and project described in this report. These engineering methods have been developed to provide the client with information regarding apparent or potential engineering conditions relating to the site within the scope cited above and are necessarily limited to conditions observed at the time of the site visit and research. Field observations and research reported herein are considered sufficient in detail and scope to form a reasonable basis for the purposes cited above.

\section{Exclusive Use}

This report was prepared for exclusive use of the property owner(s), at the time of the report, and their retained design consultants ("Client"). Conclusions and recommendations presented in this report are based on the agreed-upon scope of work outlined in this report together with the Contract for Professional Services between the Client and Materials Testing and Inspection ("Consultant"). Use or misuse of this report, or reliance upon findings hereof, by parties other than the Client is at their own risk. Neither Client nor Consultant make representation of warranty to such other parties as to accuracy or completeness of this report or suitability of its use by such other parties for purposes whatsoever, known or unknown, to Client or Consultant. Neither Client nor Consultant shall have liability to indemnify or hold harmless third parties for losses incurred by actual or purported use or misuse of this report. No other warranties are implied or expressed.

\section{Report Recommendations are Limited and Subject to Misinterpretation}

There is a distinct possibility that conditions may exist that could not be identified within the scope of the investigation or that were not apparent during our site investigation. Findings of this report are limited to data collected from noted explorations advanced and do not account for unidentified fill zones, unsuitable soil types or conditions, and variability in soil moisture and groundwater conditions. To avoid possible misinterpretations of findings, conclusions, and implications of this report, MTI should be retained to explain the report contents to other design professionals as well as construction professionals.

Since actual subsurface conditions on the site can only be verified by earthwork, note that construction recommendations are based on general assumptions from selective observations and selective field exploratory sampling. Upon commencement of construction, such conditions may be identified that require corrective actions, and these required corrective actions may impact the project budget. Therefore, construction recommendations in this report should be considered preliminary, and MTI should be retained to observe actual subsurface conditions during earthwork construction activities to provide additional construction recommendations as needed. 


\section{MATERIALS}

22 March 2018

Since geotechnical reports are subject to misinterpretation, do not separate the soil logs from the report. Rather, provide a copy of, or authorize for their use, the complete report to other design professionals or contractors. Locations of exploratory sites referenced within this report should be considered approximate locations only. For more accurate locations, services of a professional land surveyor are recommended.

This report is also limited to information available at the time it was prepared. In the event additional information is provided to MTI following publication of our report, it will be forwarded to the client for evaluation in the form received.

\section{Environmental Concerns}

Comments in this report concerning either onsite conditions or observations, including soil appearances and odors, are provided as general information. These comments are not intended to describe, quantify, or evaluate environmental concerns or situations. Since personnel, skills, procedures, standards, and equipment differ, a geotechnical investigation report is not intended to substitute for a geoenvironmental investigation or a Phase II/III Environmental Site Assessment. If environmental services are needed, MTI can provide, via a separate contract, those personnel who are trained to investigate and delineate soil and water contamination.

\section{SITE DESCRIPTION}

\section{Site Access}

Access to the site may be gained via Highway 20 westbound from Idaho Falls to its intersection with Taylor Boulevard. Proceed north on Taylor Boulevard for approximately 3.1 miles where the road turns to the east and enters the Materials and Fuels Complex. The site is located within the northern portion of the complex. Presently the site exists as a gravel surfaced laydown yard. The location is depicted on site map plates included in the Appendix.

\section{Regional Geology}

The site is located within the broad expanse of the Snake River Valley, which is directly underlain by a thick sequence of Upper Pleistocene to Holocene ( 1.6 million to 10,000 years ago) olivine tholeiite basalt lava flows. These flows covered a great majority of the Eastern Snake River Plain. Quaternary rhyolite domes dated back some 300,000 to 600,000 years ago penetrated these formations, and remain visible to the present. Sediments in the surrounding area were deposited as river floodplain from the Snake River, wind-blown loess, and from erosion of the surrounding buttes (Hughes and Thackray, 1999).

\section{General Site Characteristics}

This proposed development (sample preparation laboratory and utility corridor) consists of relatively flat and level to gently undulating terrain. In the location of the proposed sample preparation laboratory, the surface slopes gently from the south to the north. Throughout the majority of the site, poorly graded gravel fill materials were encountered at ground surface and were underlain by either native clayey or silty soils. No vegetation was noted on the project site. 


\section{MATERIALS}

22 March 2018

Regional drainage is north and west toward Big Lost River. Stormwater drainage for the site is achieved by percolation through surficial soils. The site is situated so that it is unlikely that it will receive any stormwater drainage from off-site sources. Stormwater drainage collection and retention systems are not in place on the project site. However, drainage structures are present to the north and south of the proposed building location.

\section{Regional Site Climatology and Geochemistry}

According to the Western Regional Climate Center, the average precipitation for the area is on the order of 10 to 12 inches per year, with an annual snowfall of approximately 78 inches and a range from 29 to 150 inches. The monthly mean daily temperatures range from $14^{\circ} \mathrm{F}$ to $87^{\circ} \mathrm{F}$, with daily extremes ranging from $-51^{\circ} \mathrm{F}$ to $100^{\circ} \mathrm{F}$. Winds are generally from the north or south-southwest with an annual average wind speed of approximately 9 miles per hour. Soils and sediments in the area are primarily derived from siliceous materials and exhibit low electro-chemical potential for corrosion of metals or concretes. Local aggregates are generally appropriate for Portland cement and lime cement mixtures. Surface water, groundwater, and soils in the region typically have $\mathrm{pH}$ levels ranging from 7.2 to 8.2 .

\section{SEISMIC Site Evaluation}

\section{Geoseismic Setting}

Soils on site are classed as Site Class C in accordance with Chapter 20 of the American Society of Civil Engineers (ASCE) publication ASCE/SEI 7-10. Structures constructed on this site should be designed per IBC requirements for such a seismic classification. Our investigation did not reveal hazards resulting from potential earthquake motions including: slope instability, liquefaction, and surface rupture caused by faulting or lateral spreading. Incidence and anticipated acceleration of seismic activity in the area is low.

\section{Regional Faults}

The site is situated within the Eastern Snake River Plain (ESRP). The ESRP is a structural downwarp that was formed during the Tertiary Period beginning around 17 million years ago from the migration of the North American Plate over the Yellowstone Hotspot. According to geologic maps, the nearest faults are located approximately 10 miles to the southeast of the site in the vicinity of Hells Half Acre Lava Field. However, according to a USGS Interactive Fault Map, no active faults are present in the vicinity of the project site.

\section{Historical Seismicity}

According to the USGS Earthquake Hazard Program, two historical earthquakes have been reported within approximately 50 miles of the project site with magnitudes ranging from 3.0 to 3.1 . Additionally, according the the National Geophysical Data Center (http://ngdc.noaa.gov/), no significant earthquakes have been recorded within approximately 50 miles of the project site. However, the 1983 Mount Borah Earthquake (6.9 magnitude) occurred approximately 67 miles to the northwest of the project site. 


\section{Seismic Shaking}

The USGS U.S. Seismic Design Maps were used to obtain values for ground motion at the project site. The USGS program indicates a peak ground acceleration of 0.055 (i.e., 5.5 percent of gravitational acceleration) for a probability of exceedance of $10 \%$ in 50 years and 0.106 for a probability of exceedance of $2 \%$ in 50 years at the location of the project site using a Site Class C.

\begin{tabular}{|l|c|c||}
\hline & $\begin{array}{c}\text { 10\% PE in 50 } \\
\text { Years }\end{array}$ & $\begin{array}{c}\text { 2\% PE in 50 } \\
\text { Years }\end{array}$ \\
\hline PGA & 5.5 & 10.6 \\
\hline 0.2 sec SA & 12.1 & 23.84 \\
\hline 1.0 sec SA & 4.86 & 8.99 \\
\hline
\end{tabular}

\section{Seismic Design Parameter Values}

The United States Geological Survey National Seismic Hazard Maps (2008), includes a peak ground acceleration map. The map for $2 \%$ probability of exceedance in 50 years in the Western United States in standard gravity $(\mathrm{g})$ indicates that a probability of 0.106 is appropriate for the project site.

The following section provides an assessment of the earthquake-induced earthquake loads for the site, including identification of the earthquake spectral response acceleration for short periods, $S_{M S}$, and at 1-second period, $S_{M 1}$, adjusted for site class effects as required by the 2015 IBC based on the following equations:

$$
\begin{gathered}
S_{M S}=F_{a} S_{s} \\
S_{M 1}=F_{v} S_{1}
\end{gathered}
$$

Where:

$$
\begin{gathered}
F_{a}=\text { Site coefficient defined in } 2009 \text { NEHRP Provisions. } \\
F_{v}=\text { Site coefficient defined in } 2009 \text { NEHRP Provisions. } \\
S_{s}=\text { The mapped spectral accelerations for short periods. } \\
S_{I}=\text { The mapped spectral accelerations for } 1 \text {-second periods. }
\end{gathered}
$$

The USGS National Seismic Hazards Mapping Project includes a program that provides values for ground motion at a selected site based on the same data that were used to prepare the USGS ground motion maps. The maps were developed using attenuation relationships for soft rock sites; the source model, assumptions, and empirical relationships used in preparation of the maps are described in Petersen and others (1996). The following values are based on a site specific Site Class of C.

$\mathrm{S}_{\mathrm{S}}$ and $\mathrm{S}_{1}=$ Mapped Spectral Acceleration Values

Site Class C

$\mathrm{F}_{\mathrm{a}}=1.200$

$\mathrm{F}_{\mathrm{V}}=1.676$ 


\section{MATERIALS}

22 March 2018

\begin{tabular}{|l|c|}
\hline Period $(\mathbf{s e c})$ & $\mathbf{S}_{\mathrm{a}}(\mathbf{g})$ \\
\hline 0.2 & $0.313\left(\mathrm{~S}_{\mathrm{s}}\right.$, Site Class $\left.\mathrm{C}\right)$ \\
\hline 1.0 & $0.124\left(\mathrm{~S}_{1}\right.$, Site Class $\left.\mathrm{C}\right)$ \\
\hline
\end{tabular}

$$
\begin{aligned}
& S_{M S}=0.376 \\
& S_{M 1}=0.207
\end{aligned}
$$

Design spectral response acceleration parameters as presented in the $2015 \mathrm{IBC}$ are defined as a $5 \%$ damped design spectral response acceleration at short periods, $S_{D S}$, and at 1-second period, $S_{D I}$, as calculated from the following equations:

$$
\begin{aligned}
& S_{D S}=\frac{2}{3} S_{M S} \\
& S_{D 1}=\frac{2}{3} S_{M 1}
\end{aligned}
$$

For the proposed project site, the 5\% damped design spectral response acceleration at short periods, as calculated using the program supplied by the USGS are as follows:

$$
\begin{aligned}
& S_{D S}=0.251 \\
& S_{D 1}=0.138
\end{aligned}
$$

\section{Geologic HaZARd ASSESSMENT}

This section provides an assessment of the geologic hazards for the site, including the potential for surface fault rupture, seismically induced settlements, seismically induced landsliding, lateral spreading, flooding, and collapsible soils. The hazard evaluation methodology involved on or two steps. First, the potential for occurrence of each type of geologic phenomenon is assessed. If there is a potential for a phenomenon to occur, the second step is to assess whether the phenomenon likely will result in a significant hazard for designated structures. For this evaluation, a significant hazard is defined as one that results in structural damage and threatens life-safety.

\section{Seismically Induced Surface Rupture, Settlements, and Lateral Spreading}

Earthquakes generally are caused by a sudden slip or displacement along a zone of weakness, termed a fault, in the Earth's crust. Surface fault rupture, which is a manifestation of the fault displacement at the ground surface, usually is associated with moderate to large-magnitude earthquakes (magnitudes of about 6 or larger) occurring on active faults having mapped traces or zones at the ground surface. The amount of surface fault displacement can be as much as 10 feet ( 3 meters) or more, depending on the earthquake magnitude and other factors. The displacements associated with surface fault rupture can have devastating effects on structures and lifelines situated astride the zone of rupture.

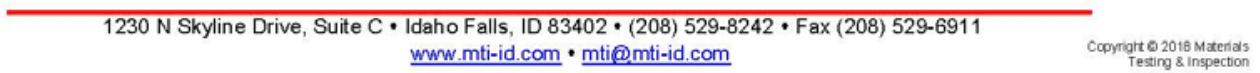




\section{MATERIALS}

22 March 2018

As mentioned above, no active faults have been mapped in the vicinity of the site. Based on the absence of nearby active faults, it is the opinion of MTI that the probability of the occurrence of seismically induced surface rupture, settlements, and lateral spreading is negligible. Based on the topographic relief across the site, the potential for flood waters at the site is negligible.

\section{Seismically Induced Landsliding}

Earthquake ground shaking can reduce the stability of a slope and cause sliding or falling of the soil or rock materials composing the slope. During ground shaking, seismic inertia forces are induced within the slope, increasing the loads that the slope materials must sustain to resist landsliding (or rockfalls). If the forces tending to cause landsliding exceed the strength of the materials resisting landsliding, a temporary instability is created that is manifested by lateral or downslope displacement of the slope materials, reducing their ability to resist the forces that cause landsliding.

Possible consequences of landsliding include differential lateral and vertical movements of structures siruated within the landslide zone, undermining of structures upslope of the landslide, burial or filling of facilities downslope of the landslide, increased loading against structures in the path of the landslide, and decreased stability of slopes above the landslide.

As discussed in the General Site Characteristics section of this report, the site is on generally flat and level ground. There are no slopes in the vicinity of the site that could fail in a "flowing" manner and impact the buildings. Based on this information, MTI concludes that the potential for seismically induced landslides at the site is low.

\section{Collapsible Potential}

Collapsible soils are soils that compact and collapse with increased moisture content. Soil particles are originally loosely packed and barely touch each other before moisture soaks into the ground. As water is added to the soils and moves downward, it wets the contacts between soil particles and allows them to slip past each other to become more tightly packed. Water also affects the clay between other soil particles so that it first expands, and then collapses like a house of cards. Another term for collapsible soils is "hydrocompactive soils" because they compact after water is added. After comparison of in-situ soil densities and general maximum densities for silt soils, collapsible soils are not anticipated on the site.

\section{SOILS EXPLORATION}

\section{Exploration and Sampling Procedures}

Field exploration conducted to determine engineering characteristics of subsurface materials included a reconnaissance of the project site and investigation by soil boring. Borings were located in the field by INL personnel. GPS coordinates and a site map showing boring locations were provided to MTI. Borings were advanced by means of a truck-mounted drilling rig equipped with continuous flight hollow-stem augers. At specified depths, samples were obtained using a standard split-spoon sampler and a modified California sampler, and Standard Penetration Test (SPT) blow counts were recorded. Uncorrected SPT blow counts are provided on logs, which can be found in the Appendix. At completion of exploration, borings were backfilled with bentonite holeplug and topped with 1 to 2 feet of excavated materials. 


\section{MATERIALS}

22 March 2018

Within bedrock, cores were advanced by means of diamond core wireline drilling using an HQ ( 2.5 inch) tube size. Percent recovery and Rock Quality Designation (RQD) were measured and recoded for each run of core. RQD is determined by adding together the length of core pieces 4 inches long and greater, then dividing by the run length. Cores were subsequently placed in core boxes for later reference.

Samples have been visually classified in the field by professional staff, identified according to boring number and depth, placed in sealed containers, and transported to our laboratory for additional testing. Subsurface materials have been described in detail on logs provided in the Appendix. Results of field and laboratory tests are also presented in the Appendix. MTI recommends that these logs not be used to estimate fill material quantities.

\section{Laboratory Testing Program}

Along with our field investigation, a supplemental laboratory testing program was conducted to determine additional pertinent engineering characteristics of subsurface materials necessary in an analysis of anticipated behavior of the proposed structures. Laboratory tests were conducted in accordance with current applicable American Society for Testing and Materials (ASTM) specifications, and results of these tests are to be found on the accompanying logs located in the Appendix. The laboratory testing program for this report included: Atterberg Limits Testing - ASTM D4318, Grain Size Analysis - ASTM C117/C136, Compressive Strength of Intact Rock Core - ASTM D7012, Laboratory Compaction Characteristics of Soil Using Modified Effort ASTM D1557, Electrical Resistivity of Soil - ASTM G187-12a, Soil Density Determination - ASTM D7263, Paticle Size Analysis of Soils - ASTM D422, and California Bearing Ratio analysis (CBR value) - ASTM D1883.

\section{Soil and Sediment Profile}

The profile below represents a generalized interpretation for the project site. Note that on site soils strata, encountered between boring locations, may vary from the individual soil profiles presented in the logs, which can be found in the Appendix.

\section{Sample Preparation Laboratory}

Poorly graded gravel with silt and sand fill materials were encountered at ground surface throughout the majority of the site. These fill materials were brownish gray, slightly moist to moist, and medium dense to dense, with fine to coarse-grained sand and 2-inch minus gravel. Varying native silt-clay-sand mixtures were encountered beneath fill materials. These soils were brown, slightly moist to moist, and soft to very stiff, with fine-grained sand. Intermittent gravel content was noted within the deeper portions of these horizons. Basalt cinders were encountered at various depths in borings SP-1, SP-4, SP-10, and SS-10. Cinders were classified as reddish brown, slightly moist, and very dense. Basalt bedrock was encountered at depth in the borings. Basalt was dark gray, moderately to slightly weathered, very closely to widely fractured, and weak to strong. 


\section{MATERIALS}

22 March 2018

\section{$\underline{\text { Utility Corridor }}$}

Silty gravel with sand fill materials were encountered at ground surface in PRH-3. These materials were brown, slightly moist to moist, and medium dense to dense, with fine to coarse-grained sand and 2-inch-minus gravel. Silt with sand soils were observed at ground surface in PRH-6. These soils were brown, slightly moist, and stiff to very stiff, with fine-grained sand. Sandy, silty clay soils underlain by sandy, silty clay with gravel soils were encountered beneath fill materials in PRH-3. These soils were brown, slightly moist, and very stiff to hard, with fine-grained sand and 1.5-inch-minus gravels. A basalt boulder was encountered in PRH-3 from 3.8 to 7.5 feet bgs. Lean clays were encountered at depth in PRH-6. These soils were brown, slightly moist, and stiff to very stiff.

During excavation, boring sidewalls were generally stable. However, moisture contents will affect wall competency with saturated soils having a tendency to readily slough when under load and unsupported.

\section{Volatile Organic Scan}

No environmental concerns were identified prior to commencement of the investigation. Therefore, soils obtained during on-site activities were not assessed for volatile organic compounds by portable photoionization detector. Samples obtained during our exploration activities exhibited no odors or discoloration typically associated with this type of contamination. No groundwater was encountered.

\section{SITE HYDROLOGY}

Existing surface drainage conditions are defined in the General Site Characteristics section. Information provided in this section is limited to observations made at the time of the investigation. Either regional or local ordinances may require information beyond the scope of this report.

\section{Groundwater}

During this field investigation, groundwater was not encountered in borings advanced to a maximum depth of 25.0 feet bgs. Soil moistures in the borings were generally slightly moist to moist throughout. In the vicinity of the project site, groundwater levels are controlled in large part by seasonal precipitation and runoff. Maximum groundwater elevations likely occur during late spring to early summer runoff season. According to Idaho Department of Water Resources (IDWR) well driller's reports in the vicinity of the project site, groundwater was measured at depths in excess of 600 feet bgs. For construction purposes, groundwater depth can be assumed to remain greater than 20 feet bgs throughout the year. 


\section{MATERIALS}

22 March 2018

\section{Soil Infiltration Rates}

Soil permeability, which is a measure of the ability of a soil to transmit a fluid, was not tested in the field. Given the absence of direct measurements, for this report an estimation of infiltration is presented using generally recognized values for each soil type and gradation. Of soils comprising the generalized soil profile for this study, sandy lean clay, sandy lean clay with gravel, silt with sand, silt with gravel, silty clay, and silty clay with gravel soils generally offer little permeability, with typical hydraulic infiltration rates of less than 2 inches per hour. Sandy silt and sandy silt with gravel soils will commonly exhibit infiltration rates from 2 to 4 inches per hour. Infiltration rates through basalt rock can be highly variable, ranging from nearly zero to greater than 6 inches per hour in some cases. Infiltration testing is required to determine site-specific infiltration rates for drainage design once proposed locations of infiltration facilities are determined.

\section{LATERAL EARTh PRESSURes}

Retaining, below-grade, or basement walls will be subject to lateral earth pressures. The magnitude of earth pressure is a function of both type and compaction of backfill behind walls within the "active" zone, and allowable rotation of the top of the wall. The active zone is defined as the wedge of soil between the surface of the wall and a plane inclined 31 degrees from vertical passing through the base of the wall. All clayey soils must be completely removed from within the active zone. When dealing with lateral earth pressures on a gravity block, a sliding frictional coefficient of 0.45 is appropriate considering granular structural fill (SP/GP) under typical conditions.

A state of plastic equilibrium is when the subject material is considered to be 1) homogeneous and unbounded and 2) at the point of incipient instability. This state is evaluated on the basis of unit weight, mechanical properties, and the definition of instability. For the purpose of this report, it is assumed that native relatively free draining soils and imported granular fill material will be the materials of concern regarding lateral earth pressures. If other materials are considered for use, MTI must be contacted to provide alternate lateral earth pressure information. Furthermore, changes in natural soil moisture, such as can be imposed by site stormwater systems, can change the values listed below.

Below-grade restrained walls, such as basement walls, should be designed based on at-rest pressures. Active pressures are appropriate under conditions where the wall moves or rotates away from the soil mass at failure. Passive pressures are used for conditions where the wall moves toward the soil mass at failure. Rotation, or lateral movement, of the top of the wall equal to 0.002 times the height of the wall will be necessary for on-site soil backfill to achieve an "active" loading condition. Lateral movement of the top of the wall equal to 0.001 times the height of the wall will be necessary for the "active" pressure condition for imported SP/GP structural backfill.

\section{Retaining Wall Backfill Materials}

For lateral earth pressure analysis, MTI anticipates that the soils of interest will be the native sandy silt/silt with sand (ML) soils encountered in the borings. Clayey soils are not suitable for use as backfill on the soil side of walls. Seismic lateral earth pressures have also been provided in the following tables, and were calculated per

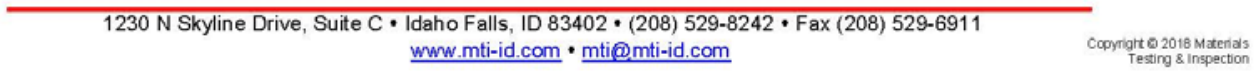


the Whitman method. For ML soils, the following values are applicable under non-surcharged, drained conditions.

\section{Lateral Earth Pressure Values for Native Soil}

\begin{tabular}{|rrrr||}
\hline Soil Type: Sandy Silt/Silt with Sand & & & \\
Internal Friction Angle: & $28^{\circ}$ & Dry Unit Weight: & $105 \mathrm{pcf}$ \\
Cohesion: & $100 \mathrm{psf}$ & Bouyant Unit Weight: & $68 \mathrm{pcf}$ \\
Natural Void Ratio: & 0.7 & Natural Moisture: & $16 \%$ \\
Wall slope to horizontal: & $90^{\circ}$ & Backfill slope: & $0^{\circ}$ \\
Wall friction angle & $14^{\circ}$ & Ground Acceleration $^{2}:$ & 0.106 \\
At rest lateral earth pressure: & $65 \mathrm{pcf}^{1}$ & $\mathrm{~K}_{\mathrm{o}}=0.53$ \\
Active lateral earth pressure: & $44 \mathrm{pcf}^{1}$ & $\mathrm{~K}_{\mathrm{a}}=0.36$ \\
Passive lateral earth pressure: & $337 \mathrm{pcf}^{1}$ & $\mathrm{~K}_{\mathrm{p}}=2.77$ \\
Seismic active lateral earth pressure: & $54 \mathrm{pcf}^{1}$ & $\mathrm{~K}_{\mathrm{ae}}=0.44$ \\
eismic passive lateral earth pressure: & $302 \mathrm{pcr}^{1}$ & & $\mathrm{~K}_{\mathrm{pe}}=2.48$ \\
\hline
\end{tabular}

${ }^{1}$ Lateral earth pressure values are in pounds per square foot, per foot of wall (psf/ft). Alternately, the values presented may also be considered as equivalent fluid with units of pounds per cubic foot (pef).

${ }^{2}$ Ground acceleration obtained from the USGS Earthquake Hazards Program.

${ }^{3}$ Values based on assumption that wall will be formed concrete.

Imported, compacted, structural material, which is used to backfill the soil side of walls, must demonstrate the following characteristics:

Lateral Earth Pressure Values for Fill Materials

\begin{tabular}{||rcrc||}
\hline Soil Type: Compacted Sandy Gravel & & & \\
Internal Friction Angle: & $35^{\circ}$ & Dry Unit Weight: & $128 \mathrm{pcf}$ \\
Cohesion: & $\mathrm{NA} \mathrm{psf}$ & Bouyant Unit Weight: & $83 \mathrm{pcf}$ \\
Natural Void Ratio: & 0.4 & Natural Moisture: & $5 \%$ \\
Wall slope to horizontal: & $90^{\circ}$ & Backfill slope: & $00^{\circ}$ \\
Wall friction angle & $24^{\circ}$ & Ground Acceleration ${ }^{2}:$ & 0.106 \\
At rest lateral earth pressure: & $57 \mathrm{pcf}^{1}$ & & $\mathrm{~K}_{\mathrm{o}}=0.43$ \\
Active lateral earth pressure: & $36 \mathrm{pcf}^{1}$ & $\mathrm{~K}_{\mathrm{a}}=0.27$ \\
Passive lateral earth pressure: & $496 \mathrm{pcf}^{1}$ & & $\mathrm{~K}_{\mathrm{p}}=3.69$ \\
Seismic active lateral earth pressure: & $47 \mathrm{pcf}^{1}$ & & $\mathrm{~K}_{\mathrm{ac}}=0.35$ \\
Seismic passive lateral earth pressure: & $443 \mathrm{pcf}^{1}$ & & $\mathrm{~K}_{\mathrm{pe}}=3.30$ \\
\hline
\end{tabular}

${ }^{1}$ Lateral earth pressure values are in pounds per square foot, per foot of wall (psf/ft). Alternately, the values presented may also be considered as equivalent fluid with units of pounds per cubic foot (pef).

${ }^{2}$ Ground acceleration obtained from the USGS Earthquake Hazards Program.

${ }^{3}$ Values based on assumption that wall will be formed concrete. 


\section{MATERIALS}

22 March 2018

In the case that another material is used for backfill, MTI should be consulted for alternate lateral earth pressure values. Granular structural fill should consist of 4-inch-minus select, clean, granular soil with no more than 30 percent oversize (greater than $3 / 4$-inch) material and no more than 5 percent fines (passing the No. 200 sieve). Retaining wall and basement backfill must be placed in accordance with recommendations in the Structural Fill section of this report and must be properly compacted and tested.

Lateral earth pressure values do not incorporate specific factors of safety, and are only applicable for nonsurcharged, drained conditions. Factors of safety, if applicable, should be integrated into the structural design of the wall. The preceding values are presented for idealized conditions relating to simple shallow structures. For complex structures, deep structures, or structures with significant perimeter landscaping, a soils engineer should be retained as part of the design team in developing appropriate project design parameters and construction specifications.

\section{Retaining Wall Drainage}

MTI recommends that a drainage system be incorporated into the retained soil mass. This can be accomplished by installing wall and toe drains as a part of each soil-supporting wall system. In areas where there is potential for significantly high soil moistures within the supported soil mass, installation of drains within the soil mass is recommended. Particular consideration of roof drain effluent and irrigation water must be made. Further, these drainage systems must be separate from other retaining wall/foundation systems. If the granular structural fill option to reduce lateral pressures is used, a compacted low permeability soil cap is recommended within the upper 2 feet of the surface to limit surface water infiltration behind the walls.

\section{FOUNDATION AND SLAB DisCUSSION AND RECOMMENDATIONS}

Various foundation types have been considered for support of the proposed structure. Two requirements must be met in the design of foundations. First, the applied bearing stress must be less than the ultimate bearing capacity of foundation soils to maintain stability. Second, total and differential settlement must not exceed an amount that will produce an adverse behavior of the superstructure. Allowable settlement is usually exceeded before bearing capacity considerations become important; thus, allowable bearing pressure is normally controlled by settlement considerations.

Considering subsurface conditions and the proposed construction, it is recommended that the structure be founded upon conventional spread footings and continuous wall footings. Total settlements should not exceed $1 / 2$-inch and differential settlement should not exceed 1/4-inch if the following design and construction recommendations are observed. 


\section{MATERIALS}

22 March 2018

\section{Foundation Design Recommendations}

Based on data obtained from the site and test results from various laboratory tests performed, MTI recommends the following guidelines for the net allowable soil bearing capacity:

\begin{tabular}{|c|c|c|}
\hline \multicolumn{3}{|c|}{ Soil Bearing Capacity } \\
\hline Foundation Depth & $\begin{array}{c}\text { ASTM D1557 } \\
\text { Subgrade Compaction }\end{array}$ & $\begin{array}{c}\text { Net Allowable } \\
\text { Soil Bearing Capacity }\end{array}$ \\
\hline $\begin{array}{l}\text { Footings and raft/mat slabs must bear on at least } 4 \text { feet of } \\
\text { compacted structural fill reinforced with two layers of Tensar } \\
\text { TX7 geogrid. Geogrid reinforced fill must bear on competent, } \\
\text { undisturbed, native sandy silt with gravel, sandy lean clay with } \\
\text { gravel, silty clay with gravel, or cinders. Existing sandy silt, } \\
\text { sandy lean clay, sandy silty clay and fill materials must be } \\
\text { completely removed from below foundation elements. }{ }^{1,2} \text { The } \\
\text { exposed subgrade should be prepared as follows: } \\
\text { 1. Twelve inches of structural fill (ISPWC Type } 1 \text { crushed } \\
\text { aggregate base) must be placed over native soils and } \\
\text { compacted to at least } 95 \% \text { of the maximum dry density as } \\
\text { determined by ASTM D1557. } \\
\text { 2. A layer of Tensar TX7 geogrid should be placed over the } \\
\text { compacted structural fill followed by } 24 \text { inches of compacted } \\
\text { structural fill. Structural fill must be placed in maximum } 12 \\
\text { inch thick loose lifts. } \\
\text { 3. Another layer of Tensar TX7 geogrid should be placed over } \\
\text { the compacted structural fill. } \\
\text { 4. At least } 12 \text { inches of compacted structural fill should be } \\
\text { placed over the top layer of geogrid. } \\
\text { See attached Plate } 4 \text { for graphical representation of system. } \\
\text { These recommendations are applicable for raft/mat slabs and } \\
\text { continuous/spread footings } 3 \text { to } 6 \text { feet wide. }\end{array}$ & $\begin{array}{l}\text { Not Required for } \\
\text { Native Soil } \\
95 \% \text { for Structural Fill }\end{array}$ & $\begin{array}{l}2,500 \mathrm{lbs} / \mathrm{ft}^{2} \\
\text { A } 1 / 3 \text { increase is } \\
\text { allowable for short-term } \\
\text { loading, which is } \\
\text { defined by seismic } \\
\text { events or designed wind } \\
\text { speeds. }\end{array}$ \\
\hline
\end{tabular}

For raft or mat slabs bearing on compacted structural fill material, a modulus of subgrade reaction, $k$ value, of 250 pei may be used. However, depending on how the slab load is applied, the value will need to be geometrically modified. The values should be adjusted for larger areas using the following expression:

Modulus of Subgrade Reaction: $k_{s}=k\left(\frac{B+1}{2 B}\right)^{2}$

where: $k_{s}=$ coefficient of vertical subgrade reaction for loaded area,

$k=$ coefficient of vertical subgrade reaction for a 1 square foot area, and $\mathrm{B}=$ effective width of area loaded, in feet. 


\section{MATERIALS}

22 March 2018

A sliding frictional coefficient value of 0.45 should be used for foundations bearing on granular structural fill. A passive lateral earth pressure of 496 pounds per square foot per foot ( $\mathrm{psf} / \mathrm{ft}$ ) should be used for compacted sandy gravel fill.

Footings should be proportioned to meet either the stated soil bearing capacity or the 2015 IBC minimum requirements. Total settlement should be limited to approximately $1 \mathrm{inch}$, and differential settlement should be limited to approximately $1 / 2$ inch. Objectionable soil types encountered at the bottom of footing excavations should be removed and replaced with structural fill. Excessively loose or soft areas that are encountered in the footings subgrade will require over-excavation and backfilling with structural fill. To minimize the effects of slight differential movement that may occur because of variations in the character of supporting soils and seasonal moisture content, MTI recommends continuous footings be suitably reinforced to make them as rigid as possible. For frost protection, the bottom of external footings should be 36 inches below finished grade.

\section{Floor Slab-on-Grade}

Fill material was encountered across the site. MTI recommends that these fill materials be compacted in place to at least 95 percent of the maximum dry density as determined by ASTM D1557. MTI personnel must be present during excavation to identify these materials.

Organic, loose, or obviously compressive materials must be removed prior to placement of concrete floors or floor-supporting fill. In addition, the remaining subgrade should be treated in accordance with guidelines presented in the Earthwork section. Areas of excessive yielding should be excavated and backfilled with structural fill. Fill used to increase the elevation of the floor slab should meet requirements detailed in the Structural Fill section. Fill materials must be compacted to a minimum 95 percent of the maximum dry density as determined by ASTM D1557.

A free-draining granular mat (drainage fill course) should be provided below slabs-on-grade. This should be a minimum of 4 inches in thickness and properly compacted. The mat should consist of a sand and gravel mixture, complying with Idaho Standards for Public Works Construction (ISPWC) specifications for $3 / 4$-inch (Type 1) crushed aggregate. A moisture-retarder should be placed beneath floor slabs to minimize potential ground moisture effects on moisture-sensitive floor coverings.

The moisture-retarder should be at least 15 -mil in thickness and have a permeance of less than 0.01 US perms as determined by ASTM E96. Placement of the moisture-retarder will require special consideration with regard to effects on the slab-on-grade and should adhere to recommendations outlined in the ACI 302.1R and ASTM E1745 publications. The granular mat should be compacted to no less than 95 percent of the maximum dry density as determined by ASTM D1557. Upon request, MTI can provide further consultation regarding installation. 


\section{MATERIALS}

\section{CONSTRUCTION CONSIDERATIONS}

Recommendations in this report are based upon structural elements of the project being founded on compacted structural fill. Structural areas should be stripped to an elevation that exposes these soil types.

\section{Earthwork}

Excessively organic soils, deleterious materials, or disturbed soils generally undergo high volume changes when subjected to loads, which is detrimental to subgrade behavior in the area of pavements, floor slabs, structural fills, and foundations. It is recommended that organic or disturbed soils, if encountered, be removed to depths of 1 foot (minimum), and wasted or stockpiled for later use. Stripping depths should be adjusted in the field to assure that the entire root zone or disturbed zone or topsoil are removed prior to placement and compaction of structural fill materials. Exact removal depths should be determined during grading operations by MTI personnel, and should be based upon subgrade soil type, composition, and firmness or soil stability. If underground storage tanks, underground utilities, wells, or septic systems are discovered during construction activities, they must be decommissioned then removed or abandoned in accordance with governing Federal, State, and local agencies. Excavations developed as the result of such removal must be backfilled with structural fill materials as defined in the Structural Fill section.

MTI should oversee subgrade conditions (i.e., moisture content) as well as placement and compaction of new fill (if required) after native soils are excavated to design grade. Recommendations for structural fill presented in this report can be used to minimize volume changes and differential settlements that are detrimental to the behavior of footings, pavements, and floor slabs. Sufficient density tests should be performed to properly monitor compaction. For structural fill beneath building structures, one in-place density test per lift for every 5,000 square feet is recommended. In parking and driveway areas, this can be decreased to one test per lift for every 10,000 square feet.

\section{Dry Weather}

If construction is to be conducted during dry seasonal conditions, many problems associated with soft soils may be avoided. However, some rutting of subgrade soils may be induced by shallow groundwater conditions related to springtime runoff or irrigation activities during late summer through early fall. Solutions to problems associated with soft subgrade soils are outlined in the Soft Subgrade Soils section. Problems may also arise because of lack of moisture in native and fill soils at time of placement. This will require the addition of water to achieve near-optimum moisture levels. Low-cohesion soils exposed in excavations may become friable, increasing chances of sloughing or caving. Measures to control excessive dust should be considered as part of the overall health and safety management plan.

\section{Wet Weather}

If construction is to be conducted during wet seasonal conditions (commonly from mid-November through May), problems associated with soft soils must be considered as part of the construction plan. During this time of year, fine-grained soils such as silts and clays will become unstable with increased moisture content, and eventually deform or rut. Additionally, constant low temperatures reduce the possibility of drying soils to near optimum conditions. 


\section{MATERIALS}

22 March 2018

\section{Soft Subgrade Soils}

Shallow fine-grained subgrade soils that are high in moisture content should be expected to pump and rut under construction traffic. During periods of wet weather, construction may become very difficult if not impossible. The following recommendations and options have been included for dealing with soft subgrade conditions:

- Track-mounted vehicles should be used to strip the subgrade of root matter and other deleterious debris. Heavy rubber-tired equipment should be prohibited from operating directly on the native subgrade and areas in which structural fill materials have been placed. Construction traffic should be restricted to designated roadways that do not cross, or cross on a limited basis, proposed roadway or parking areas.

- Soft areas can be over-excavated and replaced with granular structural fill.

- Construction roadways on soft subgrade soils should consist of a minimum 2-foot thickness of large cobbles of 4 to 6 inches in diameter with sufficient sand and fines to fill voids. Construction entrances should consist of a 6-inch thickness of clean, 2-inch minimum, angular drain-rock and must be a minimum of 10 feet wide and 30 to 50 feet long. During the construction process, top dressing of the entrance may be required for maintenance.

- Scarification and aeration of subgrade soils can be employed to reduce the moisture content of wet subgrade soils. After stripping is complete, the exposed subgrade should be ripped or disked to a depth of $1 \frac{1}{2}$ feet and allowed to air dry for 2 to 4 weeks. Further disking should be performed on a weekly basis to aid the aeration process.

- Alternative soil stabilization methods include use of geotextiles, lime, and cement stabilization. MTI is available to provide recommendations and guidelines at your request.

\section{Frozen Subgrade Soils}

Prior to placement of structural fill materials or foundation elements, frozen subgrade soils must either be allowed to thaw or be stripped to depths that expose non-frozen soils and wasted or stockpiled for later use. Stockpiled materials must be allowed to thaw and return to near-optimal conditions prior to use as structural fill.

The onsite, shallow clayey and silty soils are susceptible to frost heave during freezing temperatures. For exterior flatwork and other structural elements, adequate drainage away from subgrades is critical. Compaction and use of structural fill will also help to mitigate the potential for frost heave. Complete removal of frost susceptible soils for the full frost depth, followed by replacement with a non-frost susceptible structural fill, can also be used to mitigate the potential for frost heave. MTI is available to provide further guidance/assistance upon request. 


\section{Structural Fill}

Soils recommended for use as structural fill are those classified as GW, GP, SW, and SP in accordance with the Unified Soil Classification System (USCS) (ASTM D2487). Use of silty soils (USCS designation of GM, SM, and ML) as structural fill may be acceptable. However, use of silty soils (GM, SM, and ML) as structural fill below footings is prohibited. These materials require very high moisture contents for compaction and require a long time to dry out if natural moisture contents are too high and may also be susceptible to frost heave under certain conditions. Therefore, these materials can be quite difficult to work with as moisture content, lift thickness, and compactive effort becomes difficult to control. If silty soil is used for structural fill, lift thicknesses should not exceed 6 inches (loose), and fill material moisture must be closelv monitored at both the working elevation and the elevations of materials already placed. Following placement, silty soils must be protected from degradation resulting from construction traffic or subsequent construction.

Recommended granular structural fill materials, those classified as GW, GP, SW, and SP, should consist of a 6-inch minus select, clean, granular soil with no more than 50 percent oversize (greater than $3 / 4$-inch) material and no more than 12 percent fines (passing No. 200 sieve). These fill materials should be placed in layers not to exceed 12 inches in loose thickness. Granular structural fill is anticipated to swell approximately 10 percent from a bank condition and shrink approximately 15 percent from a loose condition. For native clayey and silty soils, swell values ranging from 15 to 20 percent should be anticipated from a bank condition and shrink roughly 5 to 10 percent from a loose condition. It is MTI's understanding that native soils are to be used for backfill along the utility corridor.

Prior to placement of structural fill materials, surfaces must be prepared as outlined in the Construction Considerations section. Structural fill material should be moisture-conditioned to achieve optimum moisture content prior to compaction. For structural fill below footings, areas of compacted backfill must extend outside the perimeter of the footings for a distance equal to the thickness of fill between the bottom of foundation and underlying soils, or 5 feet, whichever is less. All fill materials must be monitored during placement and tested to confirm compaction requirements, outlined below, have been achieved.

Each layer of structural fill must be compacted, as outlined below:

- Below Structures and Rigid Pavements: A minimum of 95 percent of the maximum dry density as determined by ASTM D1557.

- Below Flexible Pavements: A minimum of 92 percent of the maximum dry density as determined by ASTM D1557 or 95 percent of the maximum dry density as determined by ASTM D698.

The ASTM D1557 test method must be used for samples containing up to 40 percent oversize (greater than $3 / 4$ inch) particles. If material contains more than 40 percent but less than 50 percent oversize particles, compaction of fill must be confirmed by proof rolling each lift with a 10-ton vibratory roller (or equivalent) until the maximum density has been achieved. Density testing must be performed after each proof rolling pass until the in-place density test results indicate a drop (or no increase) in the dry density, defined as maximum density or "break over" point. The number of required passes should be used as the requirements on the remainder of fill placement. Material should contain sufficient fines to fill void spaces, and must not contain more than 50 percent oversize particles.

1230 N Skyline Drive, Suite C • Idaho Falls, ID $83402 \cdot(208) 529-8242 \cdot$ Fax (208) 529-6911
www.mti-id.com •mti@mti-id.com




\section{MATERIALS}

22 March 2018

\section{Backfill of Walls}

Backfill materials must conform to the requirements of structural fill, as defined in this report. For wall heights greater than 2.5 feet, the maximum material size should not exceed 4 inches in diameter. Placing oversized material against rigid surfaces interferes with proper compaction, and can induce excessive point loads on walls. Backfill shall not commence until the wall has gained sufficient strength to resist placement and compaction forces. Further, retaining walls above 2.5 feet in height shall be backfilled in a manner that will limit the potential for damage from compaction methods and/or equipment. It is recommended that only small handoperated compaction equipment be used for compaction of backfill within a horizontal distance equal to the height of the wall, measured from the back face of the wall.

Backfill should be compacted in accordance with the specifications for structural fill, except in those areas where it is determined that future settlement is not a concern, such as planter areas. In nonstructural areas, backfill must be compacted to a firm and unyielding condition.

\section{Excavations}

Shallow excavations that do not exceed 4 feet in depth may be constructed with side slopes approaching vertical. Below this depth, it is recommended that slopes be constructed in accordance with Occupational Safety and Health Administration (OSHA) regulations, Section 1926, Subpart P. Based on these regulations, on-site soils are classified as type "C" soil, and as such, excavations within these soils should be constructed at a maximum slope of $1 \frac{1}{2}$ feet horizontal to 1 foot vertical $\left(1 \frac{1 / 2}{2}: 1\right)$ for excavations up to 20 feet in height. Excavations in excess of 20 feet will require additional analysis. Note that these slope angles are considered stable for shortterm conditions only, and will not be stable for long-term conditions.

During the subsurface exploration, boring sidewalls generally exhibited little indication of collapse. For deep excavations, native soils cannot be expected to remain in position. These materials are prone to failure and may collapse, thereby undermining upper soil layers. This is especially true when excavations approach depths near the water table. Care must be taken to ensure that excavations are properly backfilled in accordance with procedures outlined in this report.

\section{Groundwater Control}

Groundwater was not encountered during the investigation and is anticipated to be below the depth of most construction. Special precautions may be required for control of surface runoff and subsurface seepage. It is recommended that runoff be directed away from open excavations. Silty and clayey soils may become soft and pump if subjected to excessive traffic during time of surface runoff. Ponded water in construction areas should be drained through methods such as trenching, sloping, crowning grades, nightly smooth drum rolling, or installing a French drain system. Additionally, temporary or permanent driveway sections should be constructed if extended wet weather is forecasted. 


\section{GENERAL COMMENTS}

When plans and specifications are complete, or if significant changes are made in the character or location of the proposed structure, consultation with MTI should be arranged as supplementary recommendations may be required. Suitability of subgrade soils and compaction of structural fill materials must be verified by MTI personnel prior to placement of structural elements. Additionally, monitoring and testing should be performed to verify that suitable materials are used for structural fill and that proper placement and compaction techniques are utilized. 


\section{REFERENCES}

American Concrete Institute (ACI) (2015). Guide for Concrete Floor and Slab Construction: ACI 302.1R. Farmington Hills, MI: ACI.

American Society of Civil Engineers (ASCE) (2013). Minimum Design Loads for Buildings and Other Structures: ASCE/SEI 7-10. Reston, VA: ASCE.

American Society for Testing and Materials (ASTM) (2013). Standard Test Method for Materials Finer than 75-um (No. 200) Sieve in Mineral Aggregates by Washing: ASTM C117. West Conshohocken, PA: ASTM

American Society for Testing and Materials (ASTM) (2014). Standard Test Method for Sieve Analysis of Fine and Coarse Aggregates: ASTM C136. West Conshohocken, PA: ASTM.

American Society for Testing and Materials (ASTM) (2007). Standard Test Method for Particle-Size Analysis of Soils: ASTMD422. West Conshohocken, PA: ASTM.

American Society for Testing and Materials (ASTM) (2012). Standard Test Methods for Laboratory Compaction Characteristics of Soil Using Standard Effort: ASTM D698. West Conshohocken, PA: ASTM.

American Society for Testing and Materials (ASTM) (2012). Standard Test Methods for Laboratory Compaction Characteristics of Soil Using Modified Effort: ASTM D1557. West Conshohocken, PA: ASTM.

American Society for Testing and Materials (ASTM) (2014). Standard Test Methods for California Bearing Ratio: ASTM D1883. West Conshohocken, PA: ASTM.

American Society for Testing and Materials (ASTM) (2011). Standard Practice for Classification of Soils for Engineering Purposes (Unified Soil Classification System): ASTM D2487. West Conshohocken, PA: ASTM.

American Society for Testing and Materials (ASTM) (2010). Standard Test Methods for Liquid Limit. Plastic Limit, and Plasticity Index of Soils: ASTM D4318. West Conshohocken, PA: ASTM.

American Society for Testing and Materials (ASTM) (2014). Standard Test Methods for Compressive Strength and Elastic Moduli of Intact Rock Core Specimens Under Varying States of Stress and Temperatures: ASTMD7012. West Conshohocken, PA: ASTM.

American Society for Testing and Materials (ASTM) (2011). Standard Specification for Plastic Water Vapor Retarders Used in Contact with Soil or Granular Fill Under Concrete Slabs: ASTM E1745. West Conshohocken, PA: ASTM.

American Society of State Highway and Transportation Officials (AASHTO) (2012). Determining Minimum Laboratory Soil Resistivity: AASHTO T-288. Washington D.C.: AASHTO.

American Society of State Highway and Transportation Officials (AASHTO) (1993). AASHTO Guide for Design of Pavement Structures 1993 . Washington D.C.: AASHTO.

Desert Research Institute. Western Regional Climate Center. [Online] Available: $<$ http://www.wrcc.dri.edu $>$ (2018)

Hughes, S.S., Thackray, G.D., (1999). Guidebook to the Geology of Eastern Idaho. Idaho Museum of Natural History in cooperation with the ISU Press Idaho State University, Pocatello, Idaho.

Idaho Geological Survey. (2004). Earthquakes in Idaho 1872-2000. [Online] Available: ‘http://129.101.67.129/livemaps/IdahoEpicenters/index.html> (2018)

Idaho Geological Survey. (2003). Miocene and Younger Faults in Idaho. [Online] Available: \ttp://www. idahogeology.org/pdf/Maps_(M)/m-08-m.pdf> (2018)

International Building Code Council (2015). International Building Code, 2015. Country Club Hills, IL: Author.

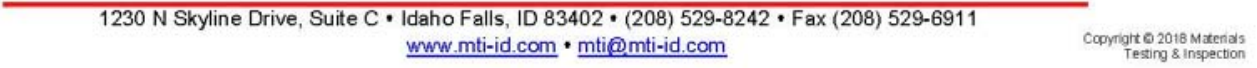


Local Highway Technical Assistance Council (LHTAC) (2017). Idaho Standards for Public Works Construction, 2017. Boise, ID: Author.

National Oceanic and Atmospheric Administration. (2016). U.S. Earthquake Intensity Database: Web Interface. [Online] Available: https://www.ngdc.noaa.gov/nndc/struts/form?t=101650\&s $=35 \& d=35>(2018)$.

U.S. Department of Labor, Occupational Safety and Health Administration. CFR 29, Part 1926, Subpart P: Safety and Health

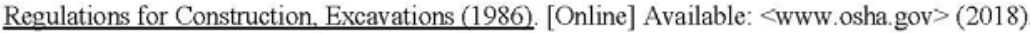

U.S. Geological Survey (2018). National Water Information System: Web Interface. [Online] Available: http://waterdata.usgs.gov/nwis> (2018)

U.S. Geological Survey. (2016). Seismic Hazard Maps and Site-Specific Data: Web Interface. [Online] Available: $<$ http://earthquake.usgs.gov/hazards/hazmaps/> (2018)

$\begin{array}{llllll}\text { U.S. Geological Survey. (2009). Seismicity of Idaho 1990-2006. } & \text { [Online] Available: }\end{array}$ http://earthquake.usgs.gov/earthquakes/states/Idaho/seismicity.php> (2018)

U.S. Geological Survey. (2011). U.S. Seismic Design Maps: Web Interface. [Online] Available: https://earthquake.usgs.gov/designmaps/us/application.php> (2018) 


\section{APPENDICES}

\section{ACRONYM LIST}

\begin{tabular}{|c|c|}
\hline AASHTO: & American Association of State Highway and Transportation Officials \\
\hline ACHD: & Ada County Highway District \\
\hline ACI & American Concrete Institute \\
\hline ASCE & American Society of Civil Engineers \\
\hline ASTM: & American Society for Testing and Materials \\
\hline bgs: & below ground surface \\
\hline CBR: & California Bearing Ratio \\
\hline D: & natural dry unit weight, pcf \\
\hline ESAL & Equivalent Single Axle Load \\
\hline GS: & grab sample \\
\hline IBC: & International Building Code \\
\hline IDEQ & Idaho Department of Environmental Quality \\
\hline ISPWC: & Idaho Standards for Public Works Construction \\
\hline ITD: & Idaho Transportation Department \\
\hline LL: & Liquid Limit \\
\hline M: & water content \\
\hline MSL: & mean sea level \\
\hline N: & Standard " $\mathrm{N}^{n}$ penetration: blows per foot, Standard Penetration Test \\
\hline NP: & nonplastic \\
\hline OSHA & Occupational Safety and Health Administration \\
\hline PCCP: & Portland Cement Concrete Pavement \\
\hline PERM: & vapor permeability \\
\hline PI: & Plasticity Index \\
\hline PD: & photoionization detector \\
\hline PVC: & polyvinyl chloride \\
\hline Qc: & cone penetrometer value, unconfined compressive strength, psi \\
\hline Qp: & Penetrometer value, unconfined compressive strength, tsf \\
\hline Qu: & Unconfined compressive strength, tsf \\
\hline RMR & Rock Mass Rating \\
\hline RQD & Rock Quality Designation \\
\hline R-Value & Resistance Value \\
\hline SPT: & Standard Penetration Test (140:pound hammer falling 30 in. on a 2 :in. split spoon) \\
\hline USCS: & Unified Soil Classification System \\
\hline USDA: & United States Department of Agriculture \\
\hline UST: & underground storage tank \\
\hline V: & vane value, ultimate shearing strength, tsf \\
\hline
\end{tabular}




\section{Geotechnical General Notes}

\begin{tabular}{|r|c|r|c|}
\hline \multicolumn{5}{|c|}{ RELATIVE DENSITY AND CoNSISTENCY CLASSIFICATION } \\
\hline Coarse-Grained Soils & \multicolumn{1}{|c|}{ SPT Blow Counts (N) } & Fine-Grained Soils & \multicolumn{1}{c|}{ SPT Blow Counts (N) } \\
\hline Very Loose: & $<4$ & Very Soft: & $<2$ \\
\hline Loose: & $4-10$ & Soft: & $2-4$ \\
\hline Medium Dense: & $10-30$ & Medium Stiff: & $4-8$ \\
\hline Dense: & $30-50$ & Stiff: & $8-15$ \\
\hline Very Dense: & $>50$ & Very Stiff: & $15-30$ \\
\hline
\end{tabular}

\begin{tabular}{|l|l|}
\hline \multicolumn{2}{|c|}{ Moisture Content } \\
\hline Description & \multicolumn{1}{c|}{ Field Test } \\
\hline Dry & Absence of moisture, dusty, dry to touch \\
\hline Moist & Damp but not visible moisture \\
\hline Wet & $\begin{array}{l}\text { Visible free water, usually soil is below } \\
\text { water table }\end{array}$ \\
\hline
\end{tabular}

\begin{tabular}{|ll|}
\hline & \multicolumn{1}{c|}{ Cementation } \\
\hline Description & \multicolumn{1}{c|}{ Field Test } \\
\hline Weakly & $\begin{array}{l}\text { Crumbles or breaks with handling or } \\
\text { slight finger pressure }\end{array}$ \\
\hline Moderately & $\begin{array}{l}\text { Crumbles or beaks with considerable } \\
\text { finger pressure }\end{array}$ \\
\hline Strongly & $\begin{array}{l}\text { Will not crumble or break with finger } \\
\text { pressure }\end{array}$ \\
\hline
\end{tabular}

\begin{tabular}{|l|l|l|l|l|l|}
\hline \multicolumn{9}{|c|}{ PARTICLE SIZE } \\
\hline Boulders: & $>12$ in. & Coarse-Grained Sand: & 5 to $0.6 \mathrm{~mm}$ & Silts: & 0.075 to $0.005 \mathrm{~mm}$ \\
\hline Cobbles: & 12 to 3 in. & Medium-Grained Sand: & 0.6 to $0.2 \mathrm{~mm}$ & Clays: & $<0.005 \mathrm{~mm}$ \\
\hline Gravel: & 3 in. to $5 \mathrm{~mm}$ & Fine-Grained Sand: & 0.2 to $0.075 \mathrm{~mm}$ & & \\
\hline
\end{tabular}

\begin{tabular}{|c|c|c|c|}
\hline \multicolumn{4}{|c|}{ UNIFIED SOIL CLASSIFICATION SYSTEM } \\
\hline \multicolumn{2}{|c|}{ Major Divisions } & Symbol & Soil Descriptions \\
\hline \multirow{8}{*}{$\begin{array}{l}\text { Coarse-Grained } \\
\text { Soils } \\
<50 \% \\
\text { passes No.200 } \\
\text { sieve }\end{array}$} & \multirow{4}{*}{$\begin{array}{c}\text { Gravel \& Gravelly } \\
\text { Soils } \\
<50 \% \\
\text { coarse fraction } \\
\text { passes No.4 sieve }\end{array}$} & GW & Well-graded gravels; gravel/sand mixtures with little or no fines \\
\hline & & GP & Poorly-graded gravels; gravel/sand mixtures with little or no fines \\
\hline & & GM & Silty gravels; poorly-graded gravel/sand/silt mixtures \\
\hline & & GC & Clayey gravels; poorly-graded gravel/sand/clay mixtures \\
\hline & \multirow{4}{*}{$\begin{array}{c}\text { Sand \& Sandy } \\
\text { Soils } \\
>50 \% \\
\text { coarse fraction } \\
\text { passes No. } 4 \text { sieve }\end{array}$} & $\overline{\mathrm{SW}}$ & Well-graded sands; gravelly sands with little or no fines \\
\hline & & SP & Poorly-graded sands; gravelly sands with little or no fines \\
\hline & & SM & Silty sands; poorly-graded sand/gravel/silt mixtures \\
\hline & & SC & Clayey sands; poorly-graded sand/gravel/clay mixtures \\
\hline \multirow{6}{*}{$\begin{array}{c}\text { Fine Grained } \\
\text { Soils }>50 \% \\
\text { passes No. } 200 \\
\text { sieve }\end{array}$} & \multirow{3}{*}{$\begin{array}{c}\text { Silts \& Clays } \\
\mathrm{LL}<50\end{array}$} & ML & Inorganic silts; sandy, gravelly or clayey silts \\
\hline & & $\mathrm{CL}$ & Lean clays; inorganic, gravelly, sandy, or silty, low to medium-plasticity clays \\
\hline & & $\mathrm{OL}$ & Organic, low-plasticity clays and silts \\
\hline & \multirow{3}{*}{$\begin{array}{l}\text { Silts \& Clays } \\
\text { LL }>50\end{array}$} & $\mathrm{MH}$ & Inorganic, elastic silts; sandy, gravelly or clayey elastic silts \\
\hline & & $\mathrm{CH}$ & Fat clays; high-plasticity, inorganic clays \\
\hline & & $\mathrm{OH}$ & Organic, medium to high-plasticity clays and silts \\
\hline \multicolumn{2}{|c|}{ Highly Organic Soils } & PT & Peat, humus, hydric soils with high organic content \\
\hline
\end{tabular}




\section{Rock Classification System}

\begin{tabular}{|c|l|}
\hline \multicolumn{2}{|c|}{ WEATHERING } \\
\hline WEATHERING & \multicolumn{1}{|c|}{ FIELD TEST } \\
\hline Fresh & No sign of decomposition or discoloration. Rings under hammer impact. \\
\hline Slightly Weathered & Slight discoloration inwards from open fractures, otherwise similar to Fresh. \\
\hline Moderately Weathered & $\begin{array}{l}\text { Discoloration throughout. Weaker minerals such as feldspar decomposed. Strength } \\
\text { somewhat less than fresh rock but cores cannot be broken by hand or scraped with a knife. } \\
\text { Texture preserved. }\end{array}$ \\
\hline Highly Weathered & $\begin{array}{l}\text { Most minerals somewhat decomposed. Specimens can be broken by hand with effort or } \\
\text { shaved with knife. Core stones present in rock mass. Texture becoming indistinct but fabric } \\
\text { preserved. }\end{array}$ \\
\hline Completely Weathered & $\begin{array}{l}\text { Minerals decomposed to soil but fabric and structure preserved. Specimens easily crumbled } \\
\text { or penetrated. }\end{array}$ \\
\hline \hline
\end{tabular}

\begin{tabular}{|c|c|}
\hline \multicolumn{2}{|c|}{ FRACTURING } \\
\hline SPACING & DISCRIPTION \\
\hline $6 \mathrm{ft}$. & Very widely \\
$2-6 \mathrm{ft}$. & Widely \\
$8-24 \mathrm{in.}$ & Moderately \\
$21 / 2-8 \mathrm{in.}$ & Closely \\
$3 / 4-21 / 2 \mathrm{in}$. & Very Closely \\
\hline
\end{tabular}

\begin{tabular}{||c|c|}
\hline \multicolumn{2}{|c|}{ ROCK QUALITY DESIGNATION (RQD) } \\
\hline RQD (\%) & ROCK QUALITY \\
\hline $90-100$ & Excellent \\
$75-90$ & Good \\
$50-75$ & Fair \\
$25-50$ & Poor \\
$0-25$ & Very Poor \\
\hline
\end{tabular}

\begin{tabular}{|c|c|c|c|}
\hline \multicolumn{4}{|c|}{ COMPETENCY } \\
\hline STRENGTH & CLASS & FIELD TEST & $\begin{array}{l}\text { APPROXIMATE RANGE OF } \\
\text { UNCONFINED } \\
\text { COMPRESSIVE STRENGTH } \\
\text { (tsf) }\end{array}$ \\
\hline Extremely Strong & I & $\begin{array}{l}\text { Many blows with geologic hammer required to break } \\
\text { intact specimen. }\end{array}$ & $>2000$ \\
\hline Very Strong & II & $\begin{array}{l}\text { Hand-held specimen breaks with pick end of hammer } \\
\text { under more than one blow. }\end{array}$ & $2000-1000$ \\
\hline Strong & III & $\begin{array}{l}\text { Cannot be scraped or peeled with knife, hand-held } \\
\text { specimen can be broken with single moderate blow } \\
\text { with pick end of hammer. }\end{array}$ & $1000-500$ \\
\hline $\begin{array}{l}\text { Moderately } \\
\text { Strong }\end{array}$ & IV & $\begin{array}{l}\text { Can just be scraped or peeled with knife. Indentations } \\
1 \mathrm{~mm} \text { to } 3 \mathrm{~mm} \text { show in specimen with moderate blow } \\
\text { with pick end of hammer. }\end{array}$ & $500-250$ \\
\hline Weak & V & $\begin{array}{l}\text { Material crumbles under moderate blow with pick end } \\
\text { of hammer and can be peeled with a knife, but is hard } \\
\text { to hand-trim for tri-axial test specimen. }\end{array}$ & $250-10$ \\
\hline Friable & VI & Material crumbles in hand. & N/A \\
\hline
\end{tabular}




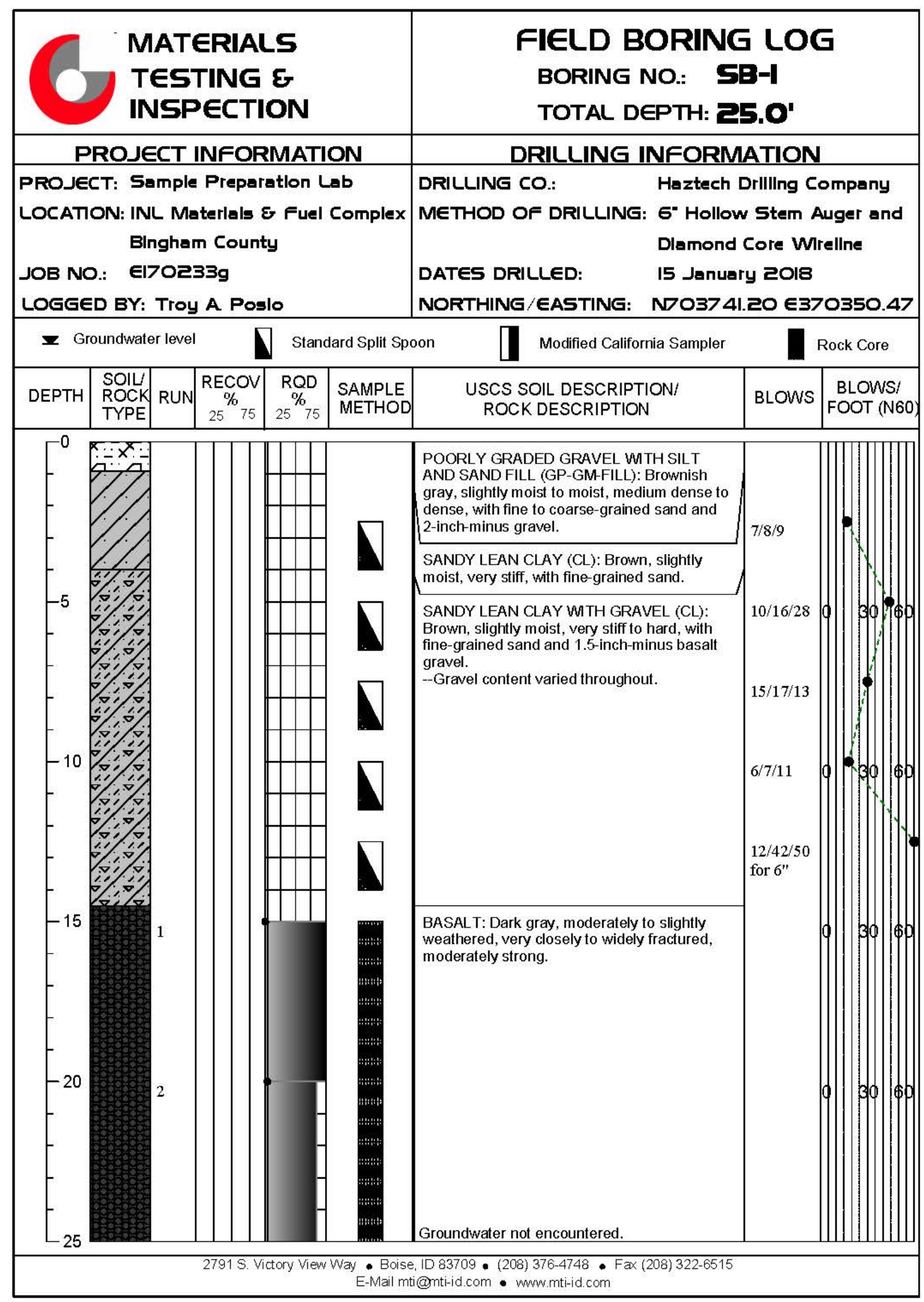




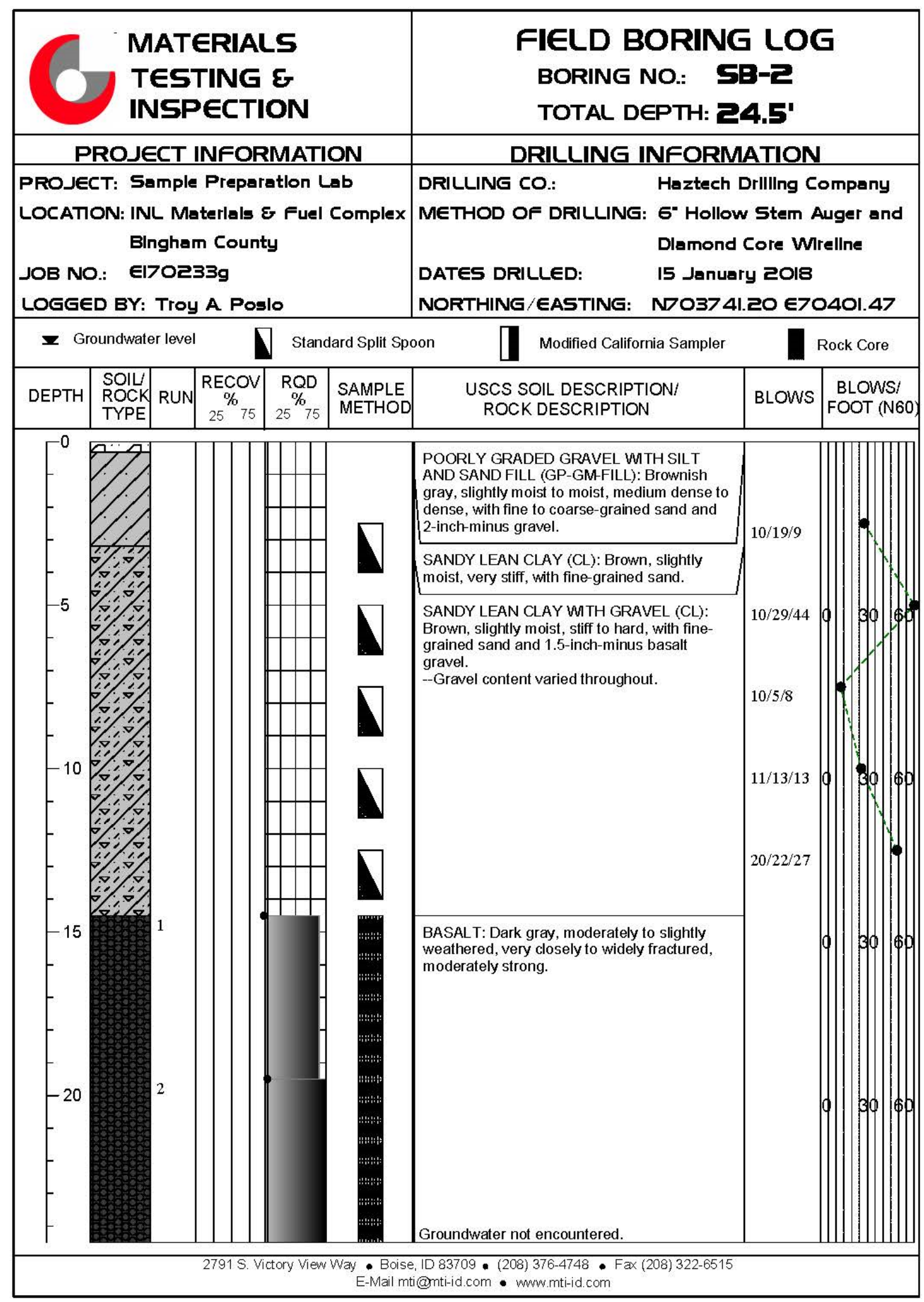




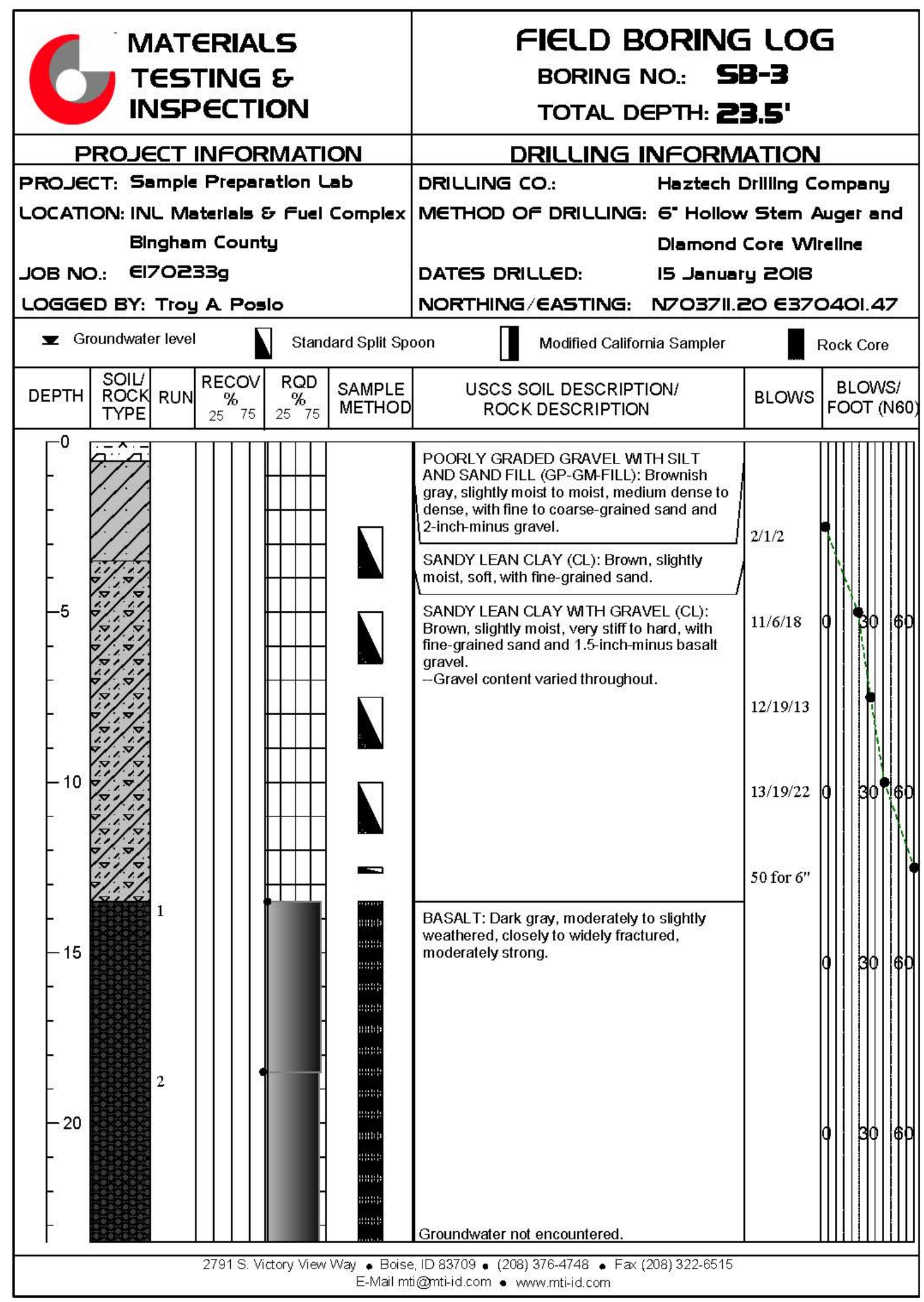




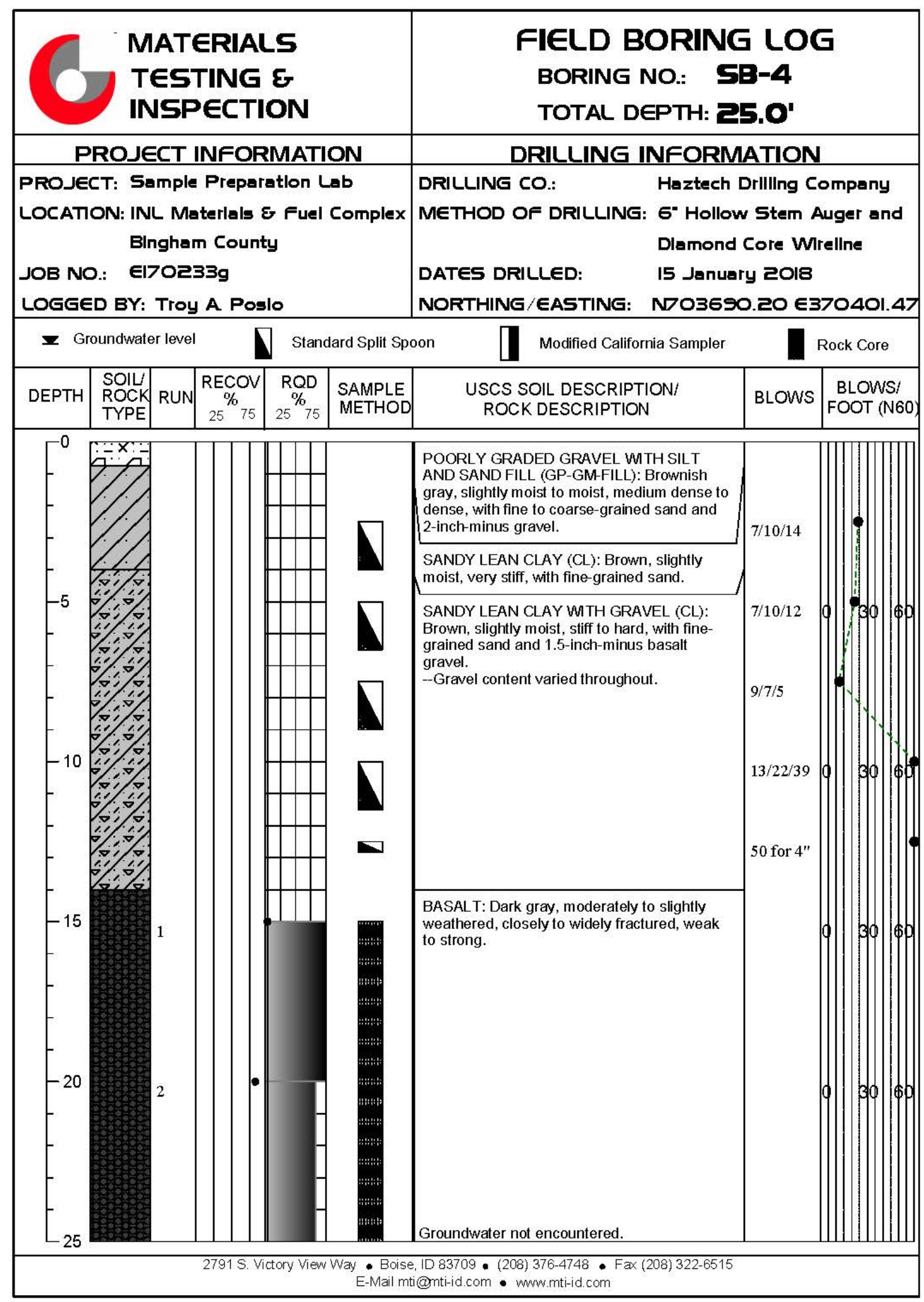




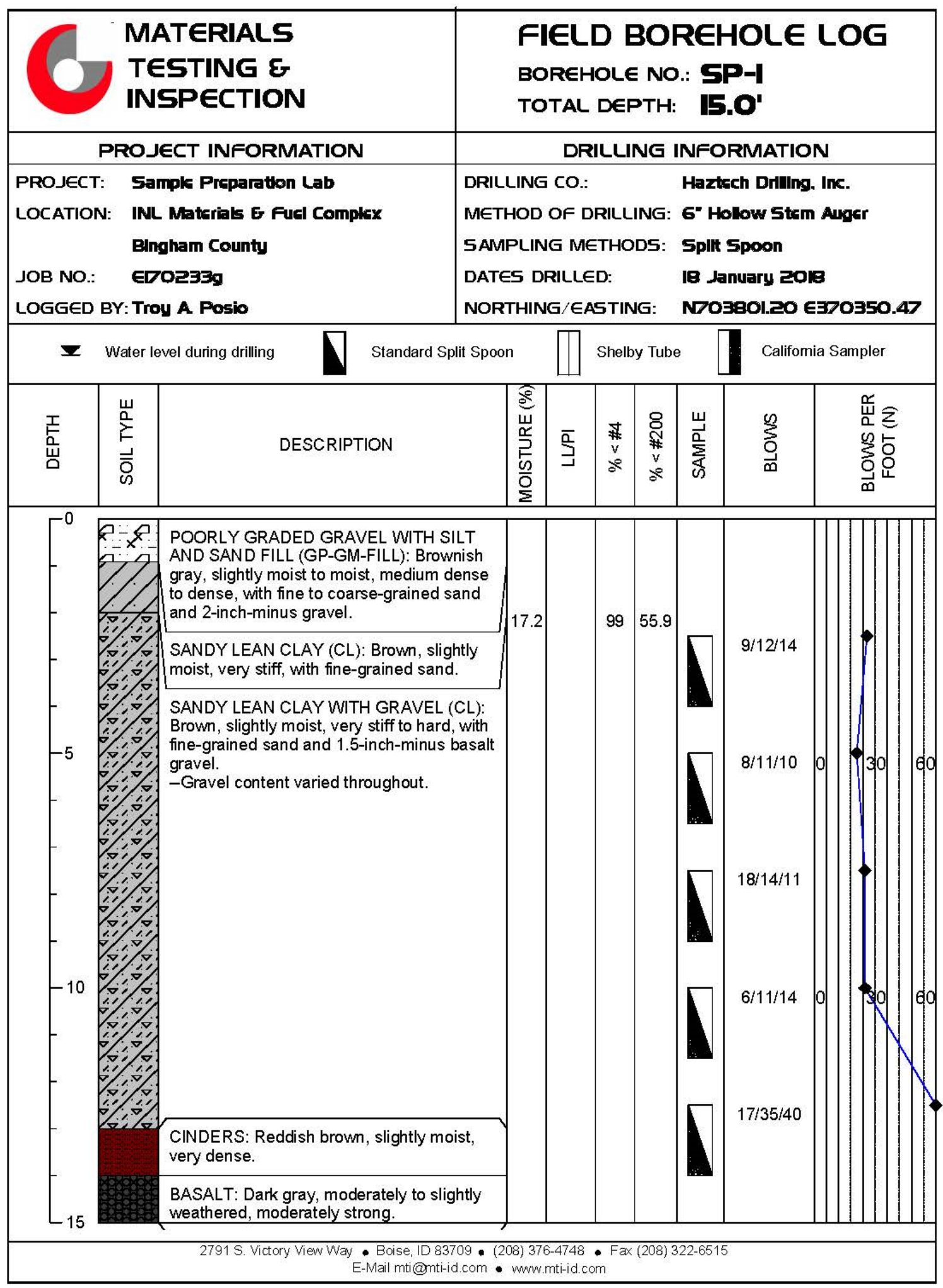




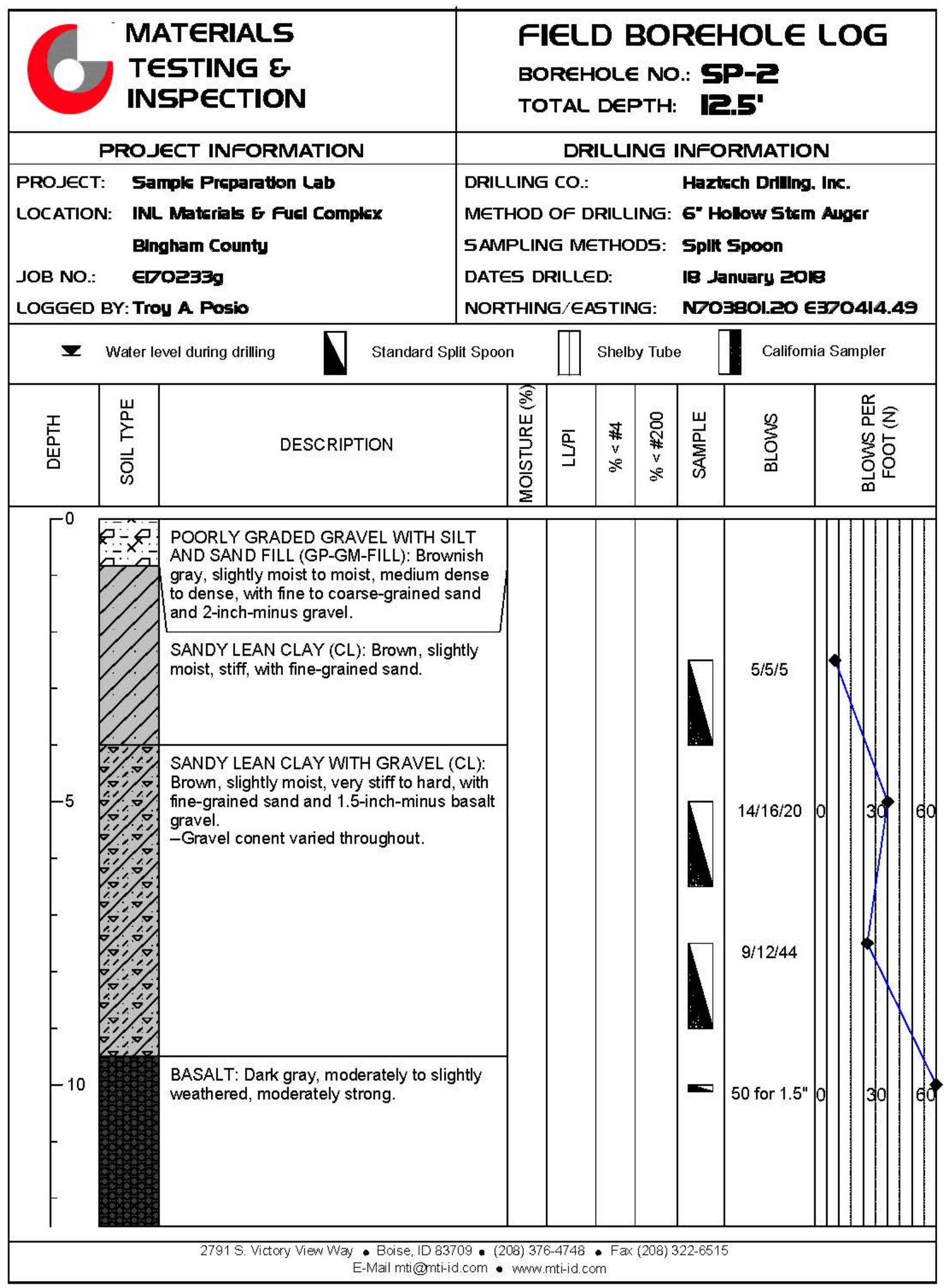




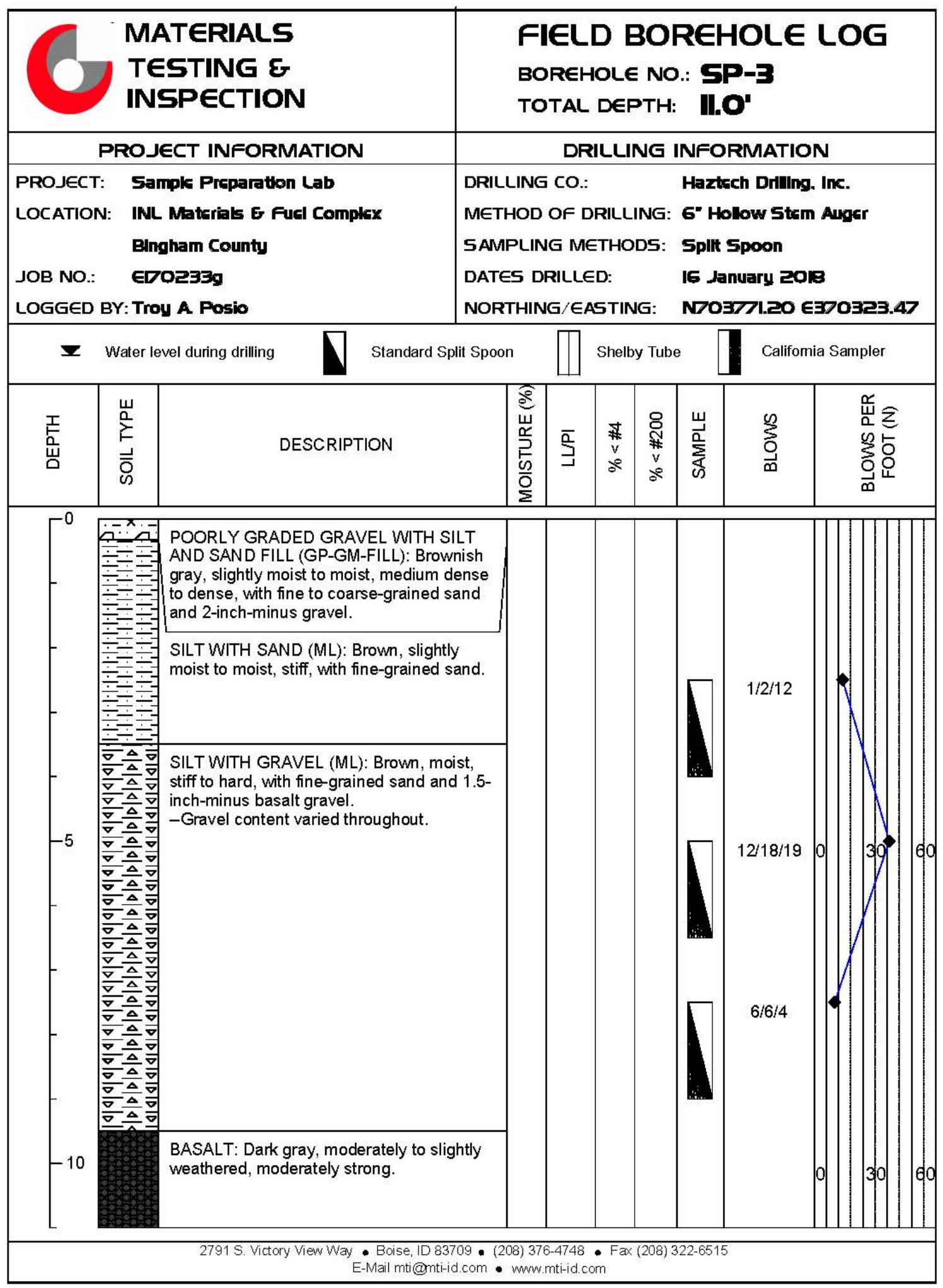




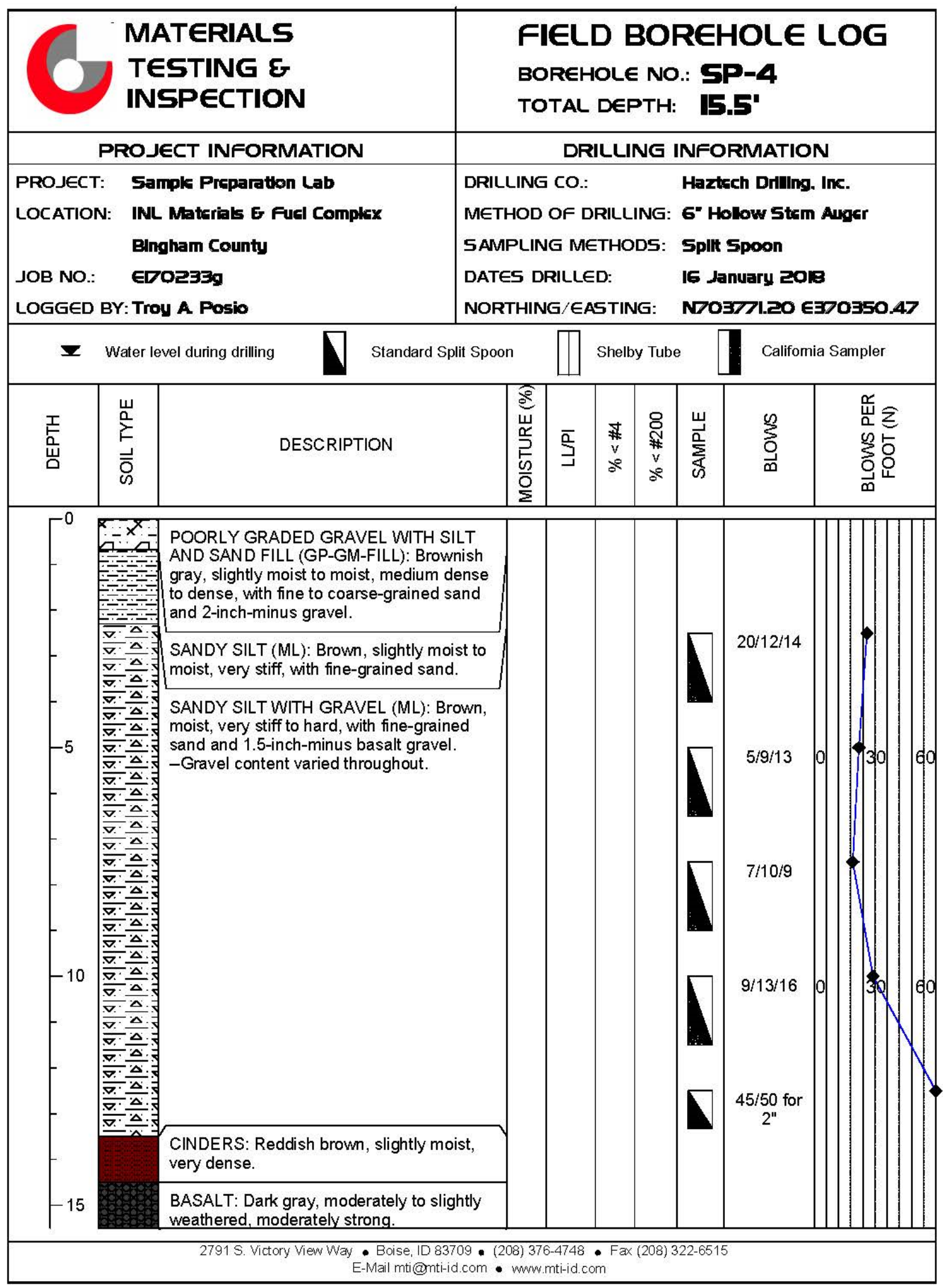




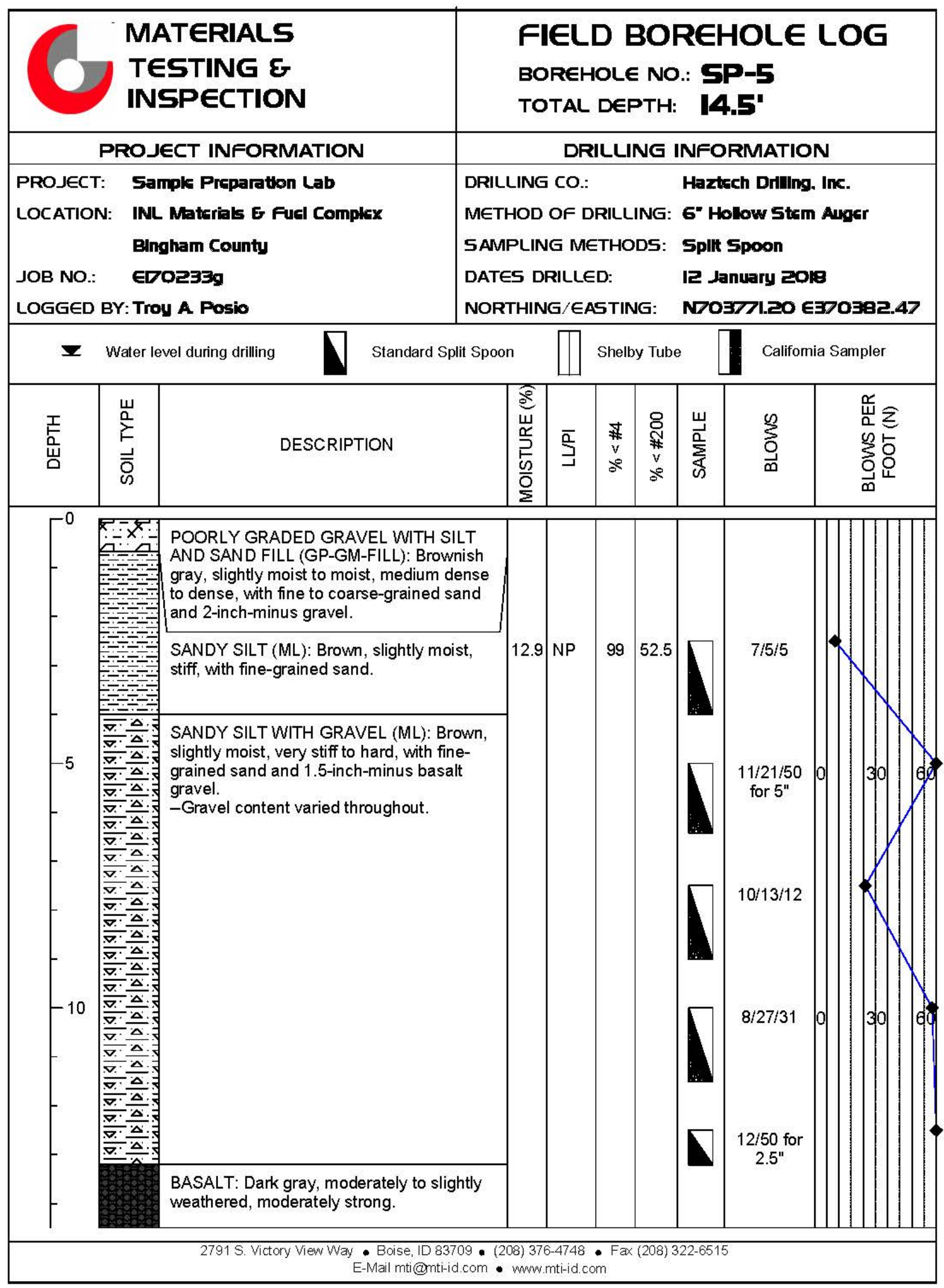




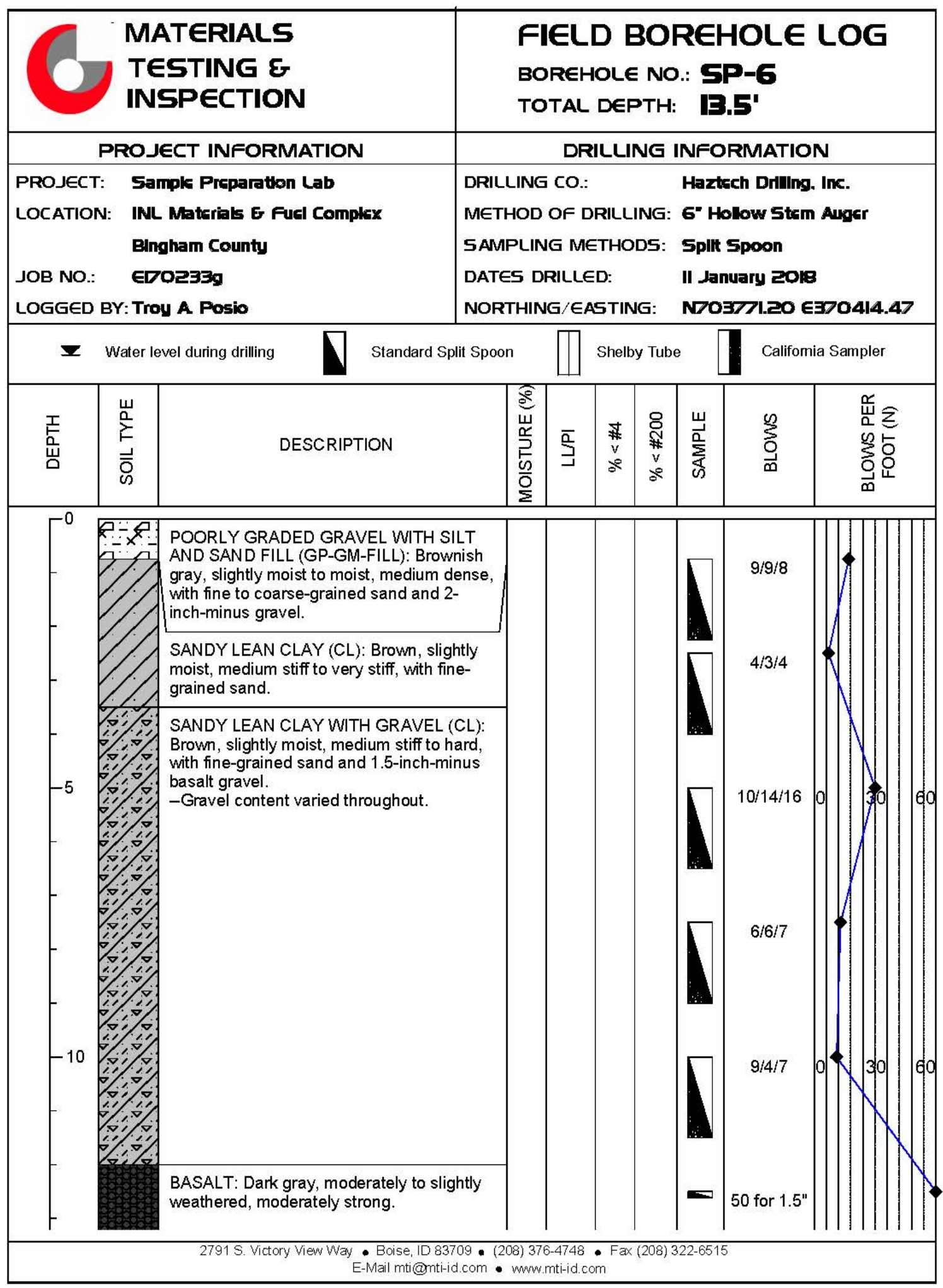




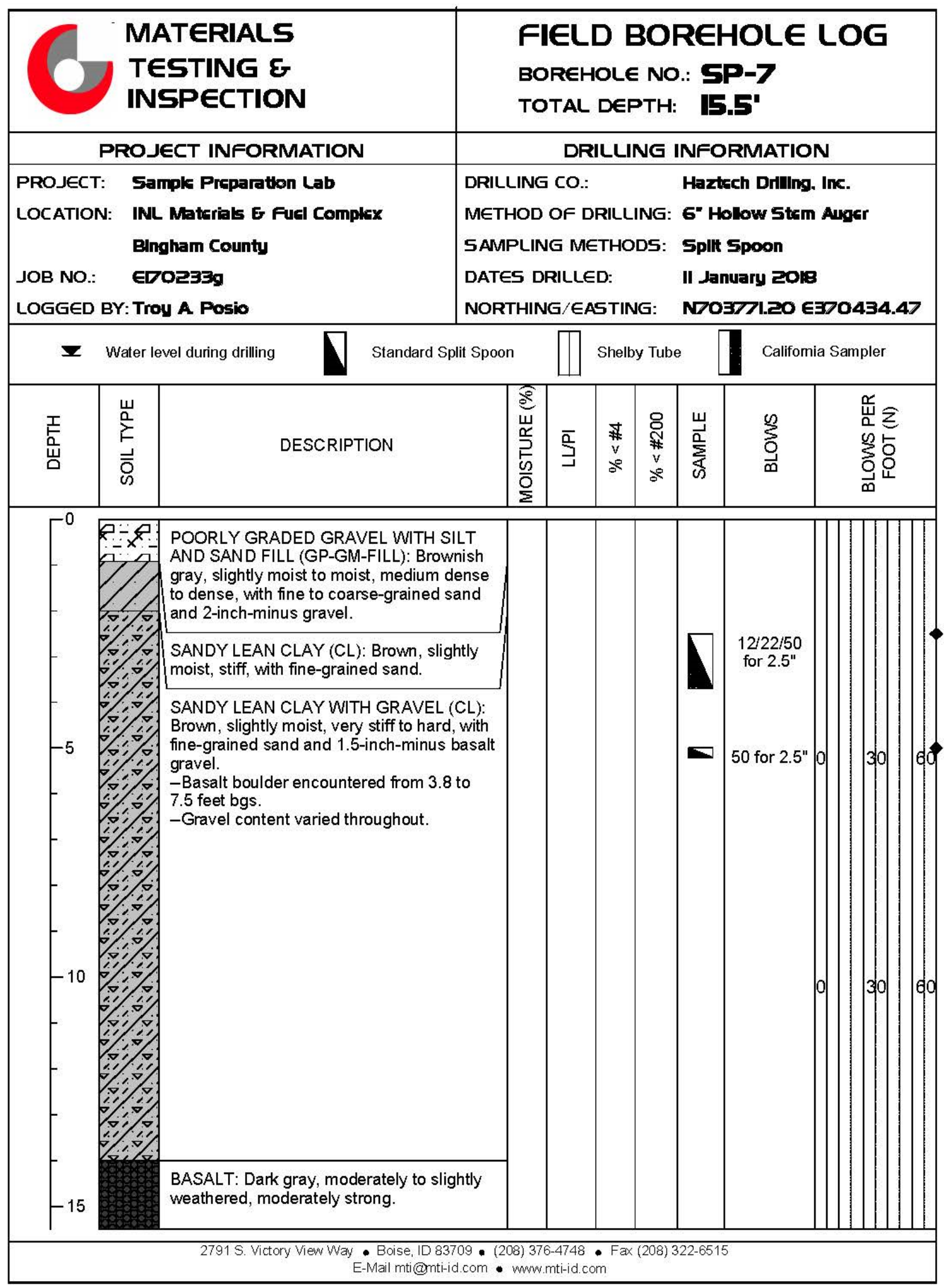




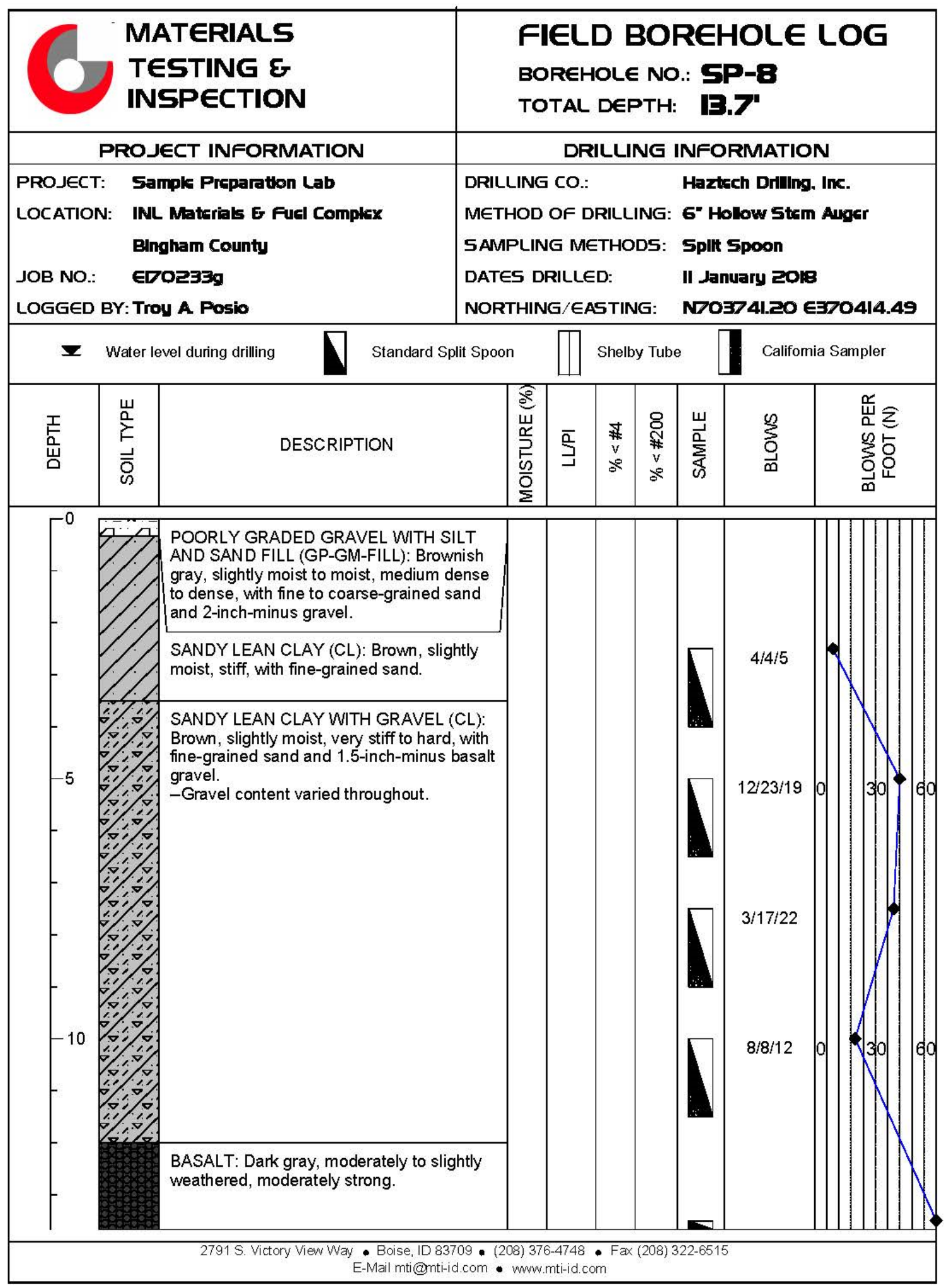




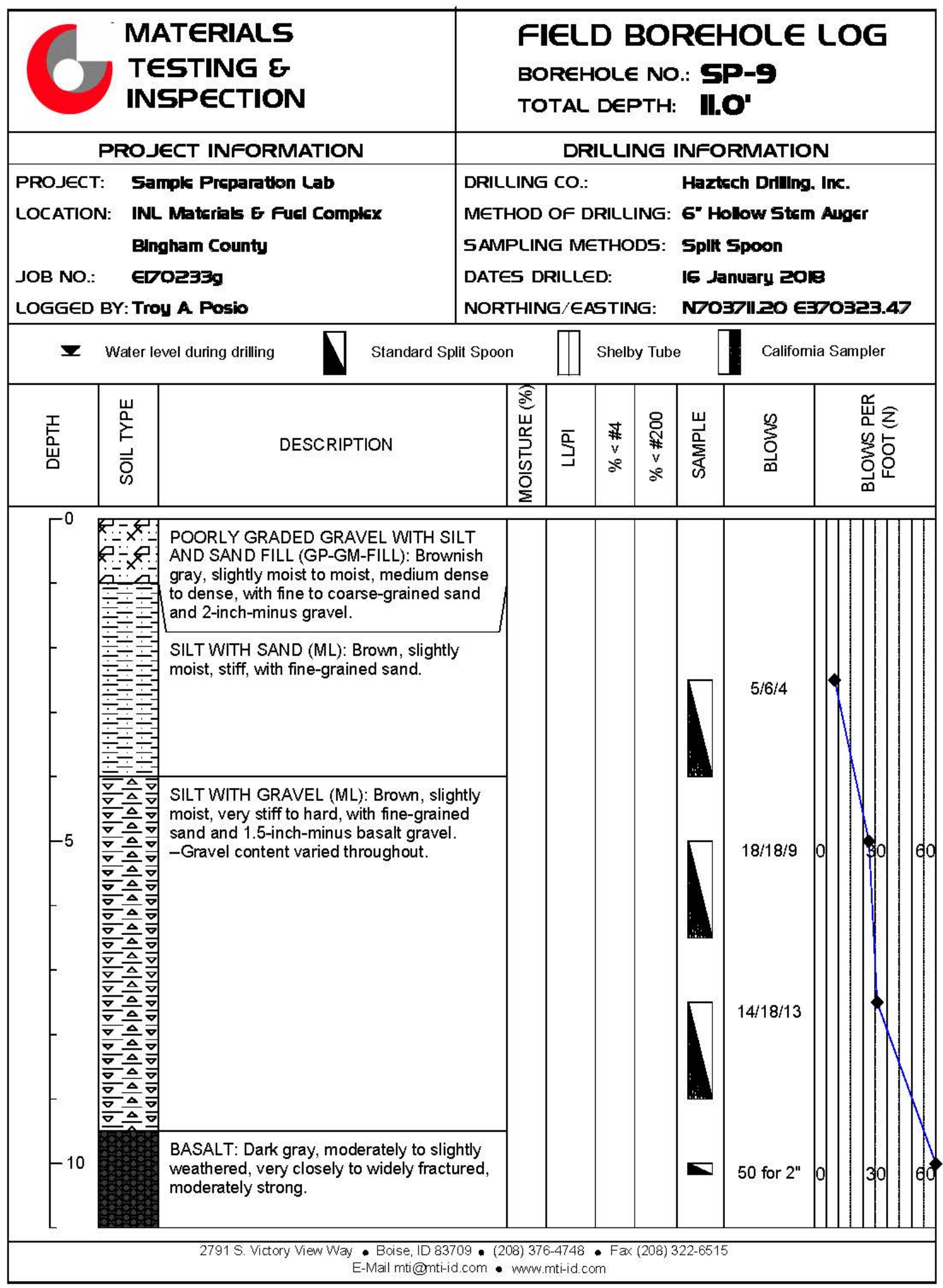




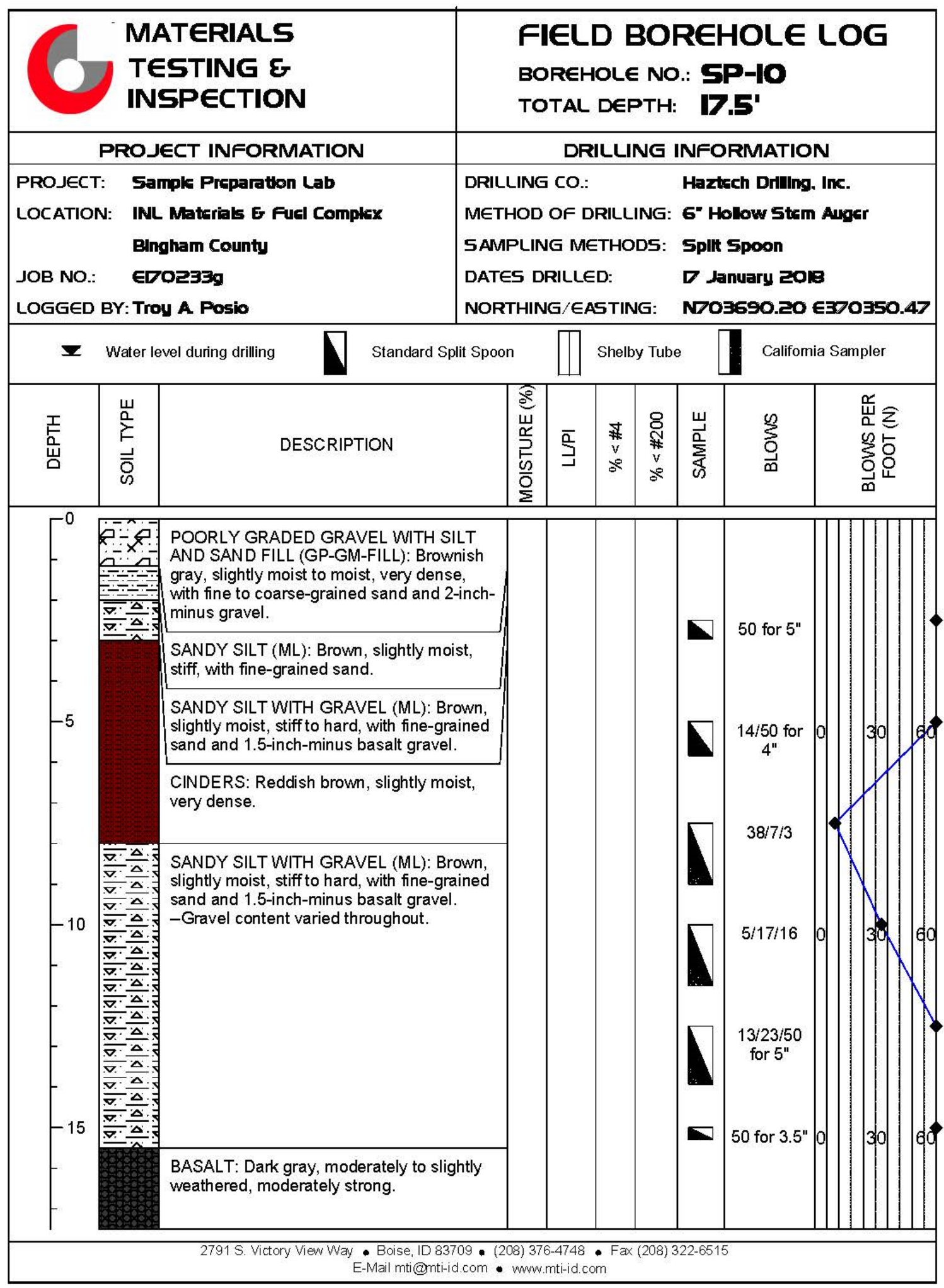




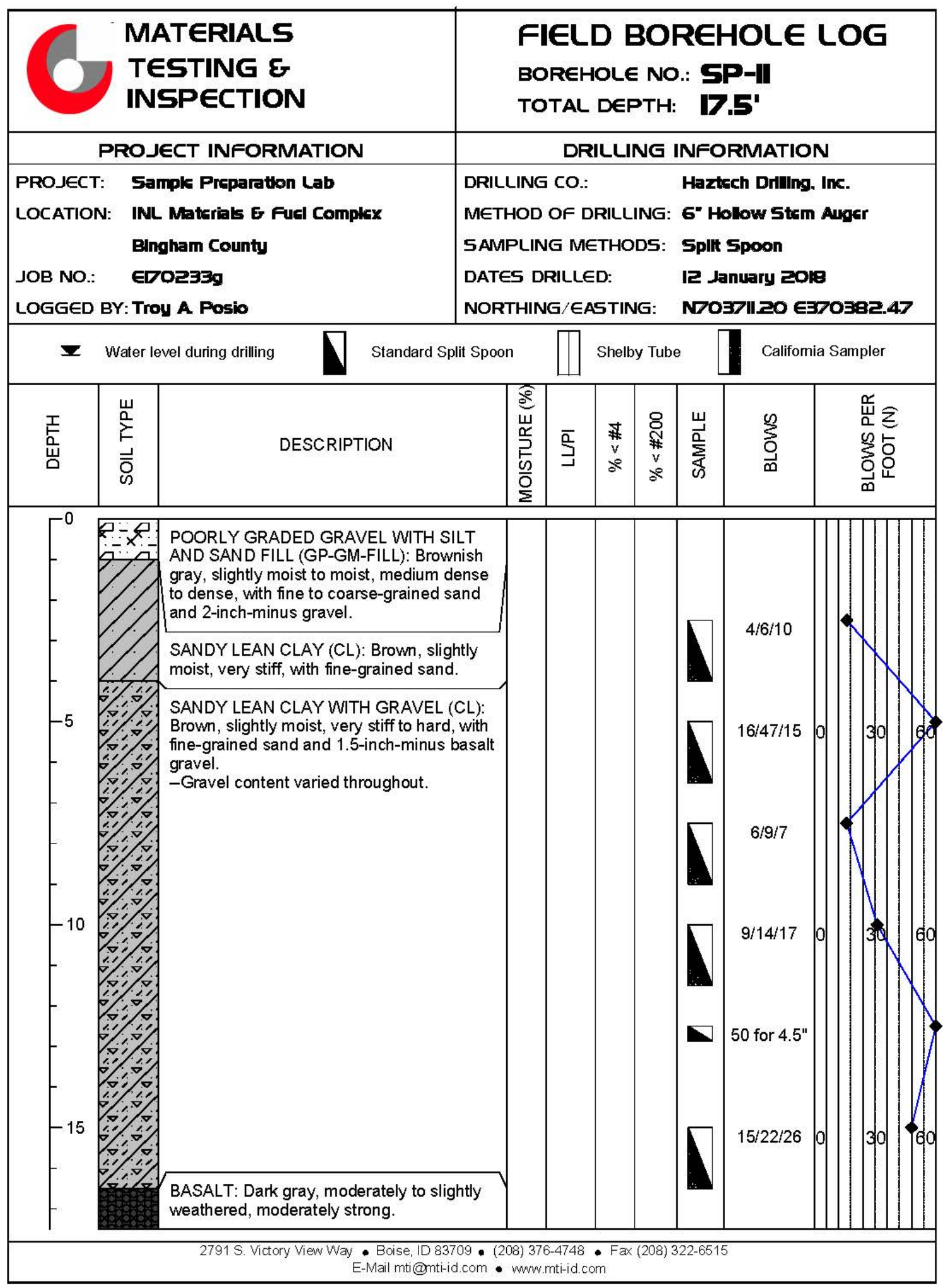




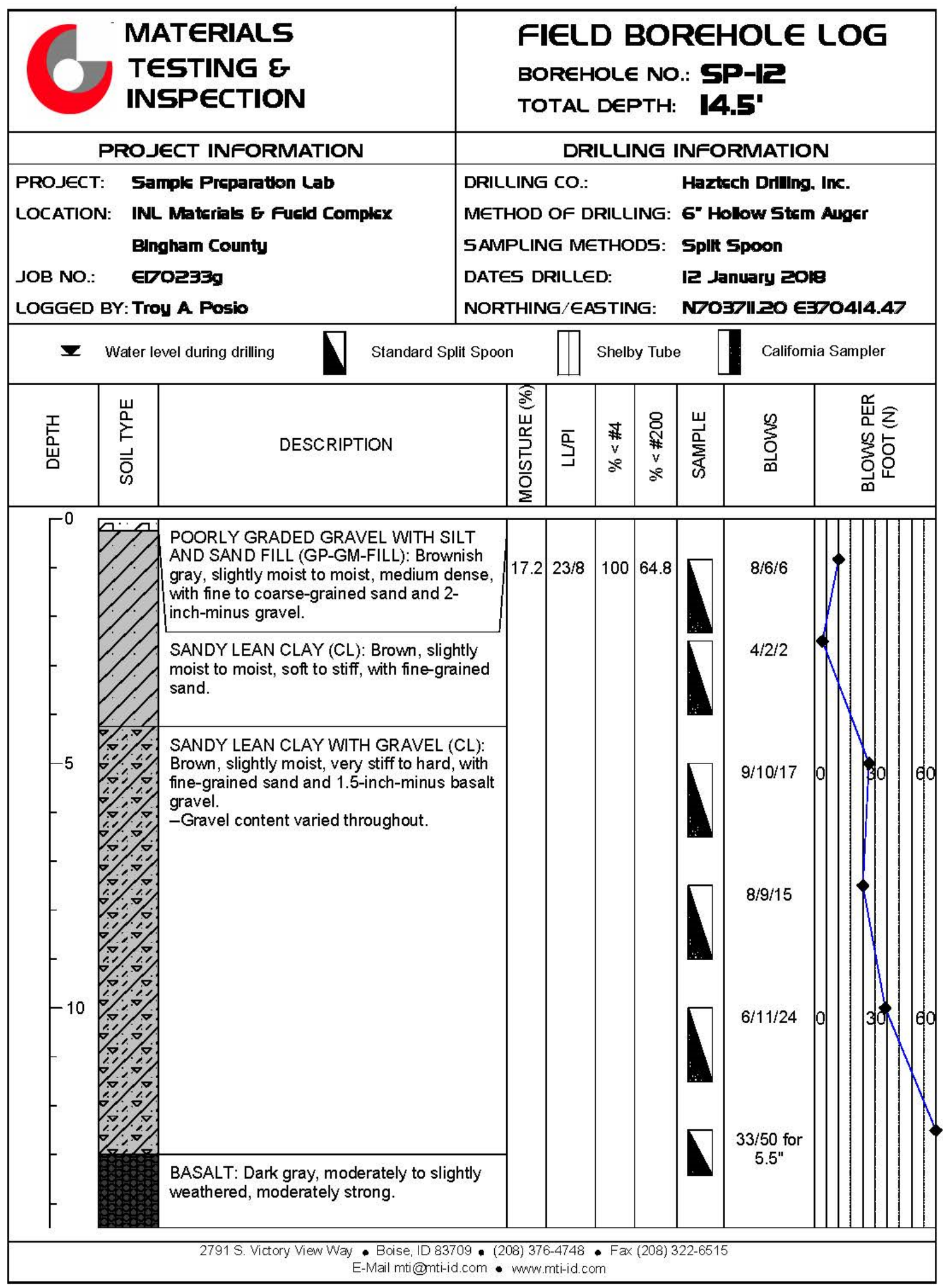




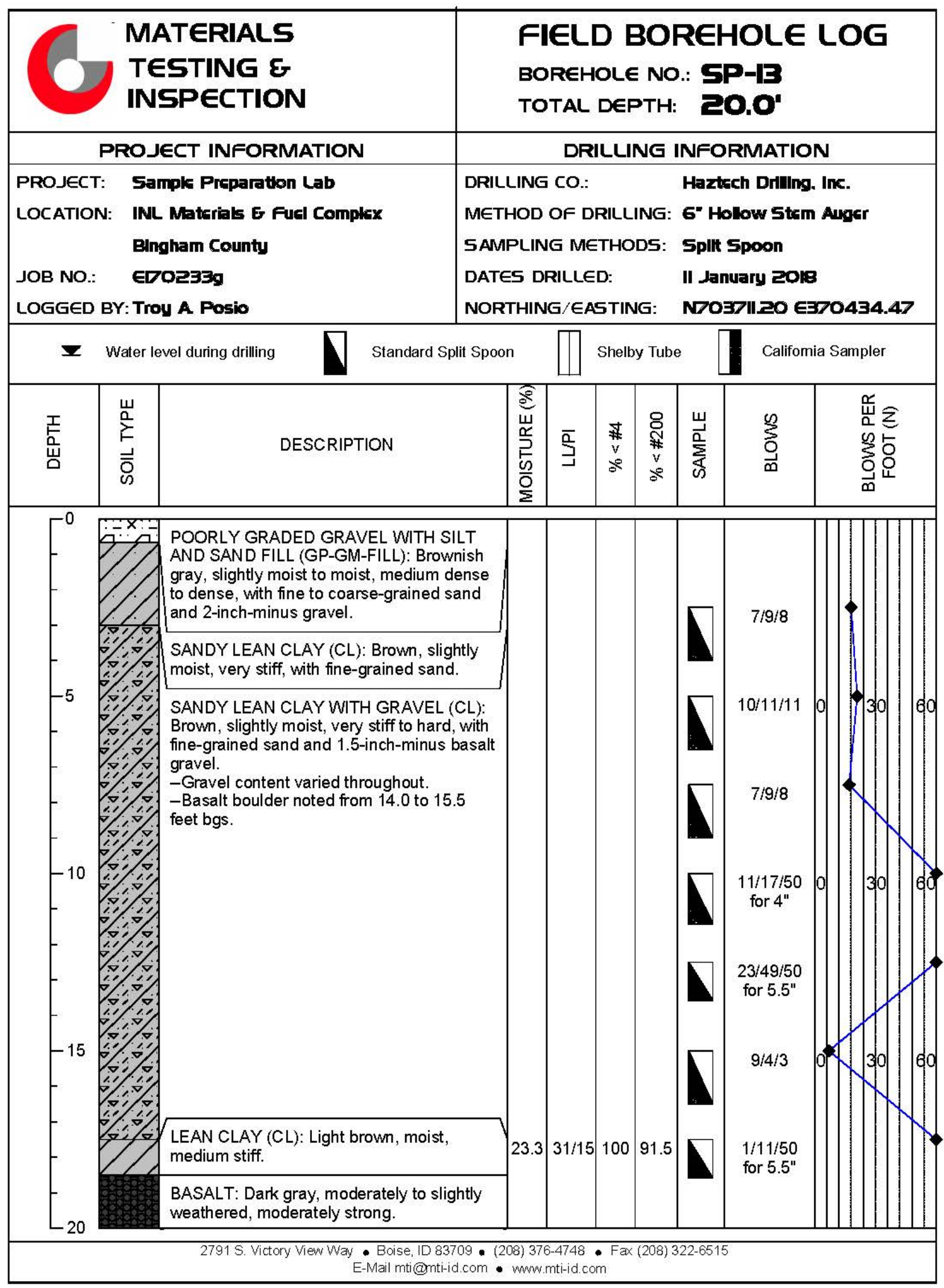




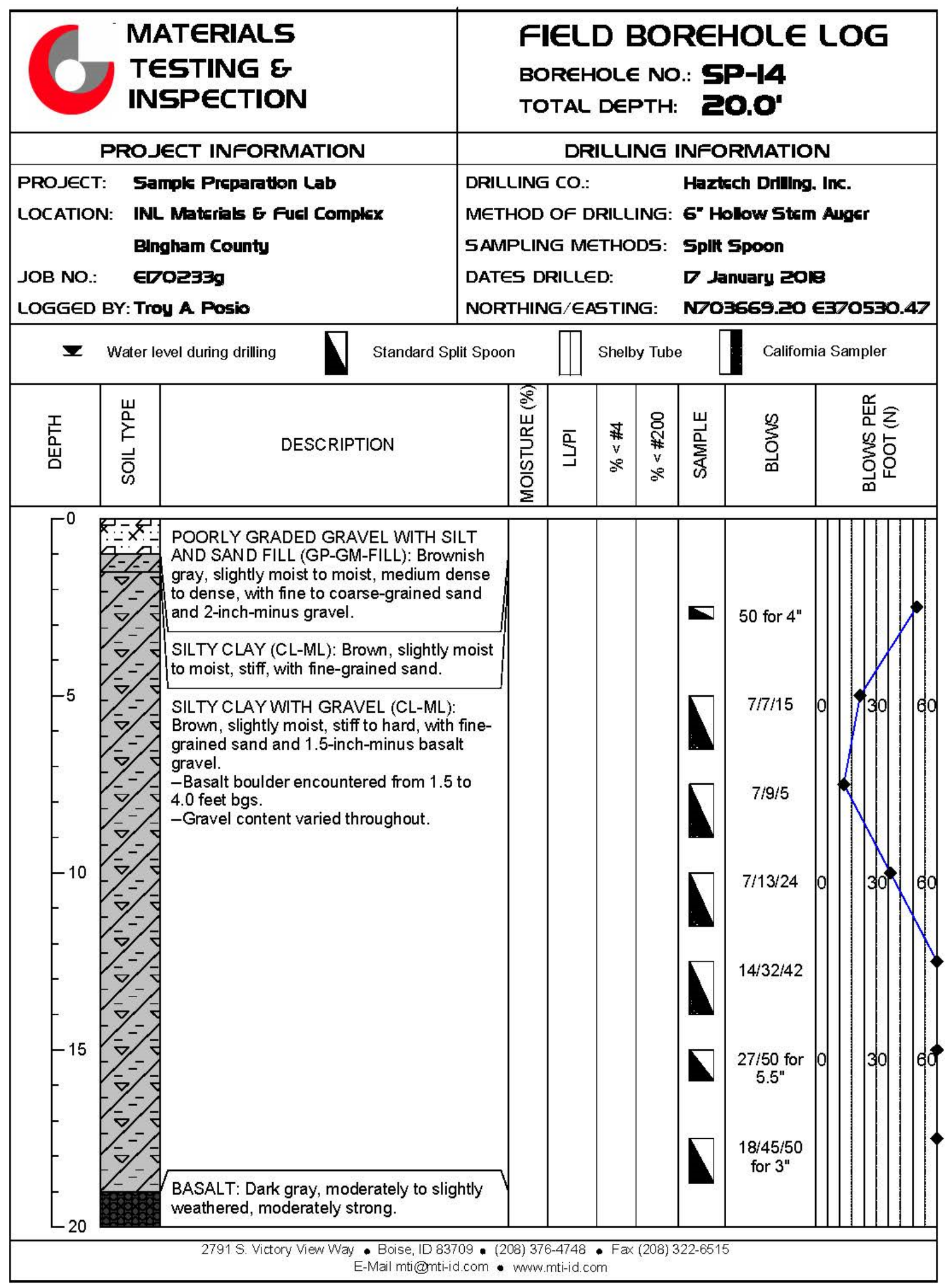




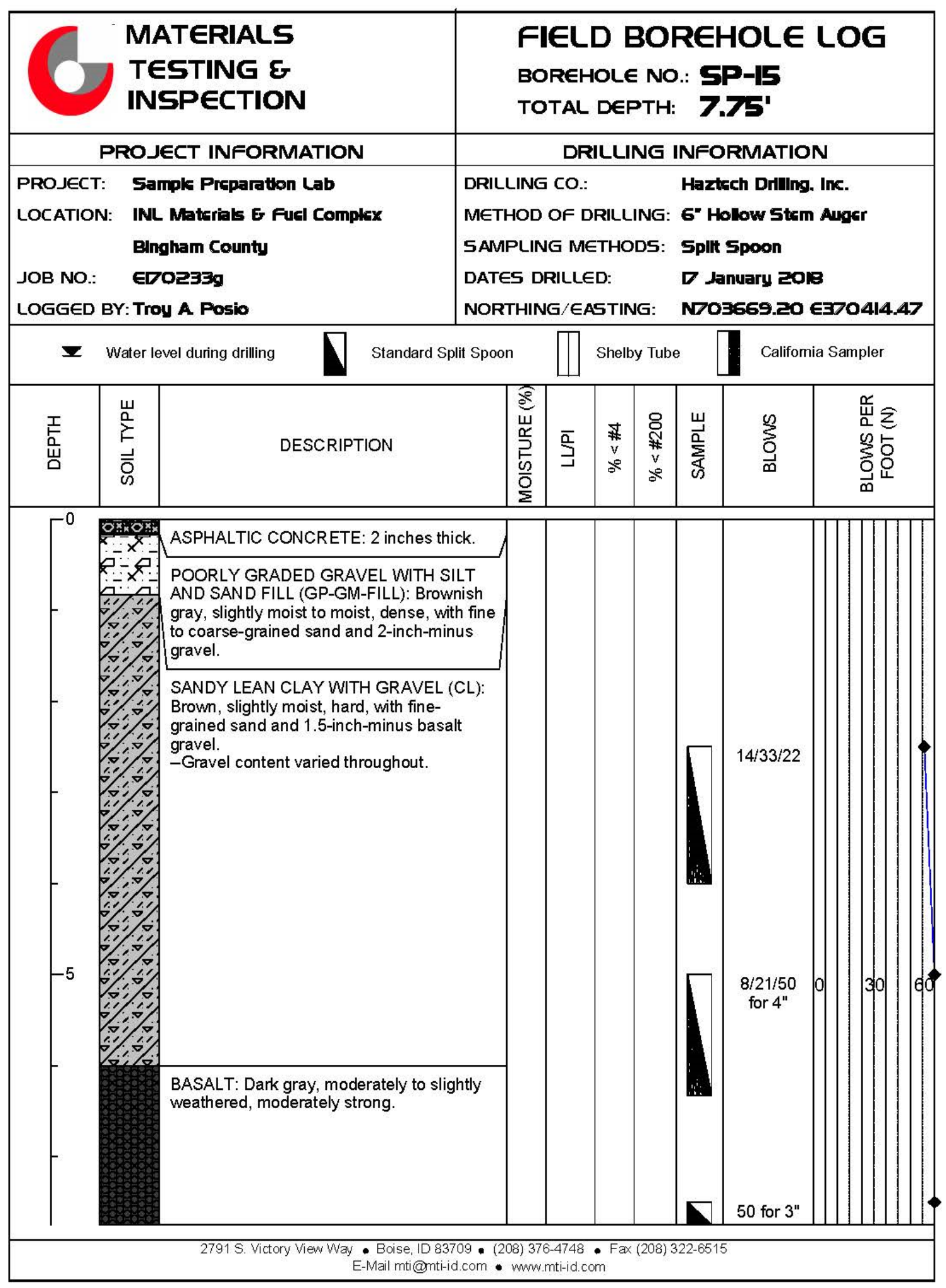




\begin{tabular}{|c|c|c|c|c|c|c|c|c|c|c|}
\hline 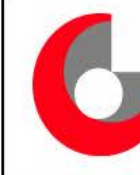 & $\begin{array}{l}\text { MA } \\
\text { TE } \\
\text { IN }\end{array}$ & $\begin{array}{l}\text { ATERIALS } \\
\text { :STING E } \\
\text { SPECTION }\end{array}$ & & $\begin{array}{l}\text { Fl } \\
\text { Bo } \\
\text { To }\end{array}$ & L & $\begin{array}{l}\text { E } \\
\text { E } \\
E\end{array}$ & $\begin{array}{l}3 \mathrm{OF} \\
\text { No } \\
\text { TH: }\end{array}$ & $\begin{array}{l}\text { REI } \\
\text { IE }\end{array}$ & $\begin{array}{c}\text { OLE } \\
07 \\
0\end{array}$ & $\mathbf{G}$ \\
\hline & PROJ & ECT INFORMATION & & & DR & LuII & VG II & $\mathrm{N} F \mathrm{C}$ & MATIOI & \\
\hline $\begin{array}{l}\text { PROJECT } \\
\text { LOCATIO } \\
\text { JOB NO.: } \\
\text { LOGGED }\end{array}$ & $\begin{array}{l}\text { T: Sar } \\
\text { N: INL } \\
\text { Bing } \\
\text { ED } \\
\text { BY: Tro }\end{array}$ & $\begin{array}{l}\text { mple Preparation Lab } \\
\text { Materials E Fucl Complex } \\
\text { gham County } \\
\text { O233g } \\
\text { Y A Posio }\end{array}$ & $\begin{array}{l}\text { DRILL } \\
\text { METH } \\
\text { SAMP } \\
\text { DATE: } \\
\text { NORT }\end{array}$ & $\begin{array}{l}\text { ING } \\
\text { IOD } \\
\text { LIN } \\
5 \text { DF } \\
\text { HIN }\end{array}$ & $\begin{array}{l}\text { CO.: } \\
\text { DF D } \\
\text { ME } \\
\text { ILE }\end{array}$ & $\begin{array}{l}\text { RILLI } \\
\text { THO } \\
\text { D: } \\
\text { 5TIN }\end{array}$ & $\begin{array}{l}\text { ING: } \\
\text { DS: } \\
\text { IG: }\end{array}$ & $\begin{array}{l}\text { Hazt } \\
6=4 \\
\text { Split } \\
16 \mathrm{~J} \\
\text { NDO }\end{array}$ & $\begin{array}{l}\text { ch Drilling. } \\
\text { low Stem } \\
\text { Spoon } \\
\text { nuary 201 } \\
\text { yol.20 E }\end{array}$ & acr \\
\hline$\underline{z}$ & Water le & vel during drilling & t Spoon & & & Shelb & y Tube & & Califom & ampler \\
\hline $\begin{array}{l}\text { I } \\
\frac{\mathrm{D}}{\mathrm{u}}\end{array}$ & 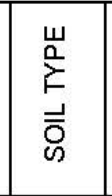 & DESCRIPTION & & 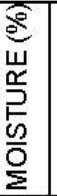 & $\overline{\bar{g}}$ & $\begin{array}{l}\text { \# } \\
v \\
v \\
o\end{array}$ & $\begin{array}{l}\text { Oे } \\
\text { ॠ } \\
v \\
\text { o }\end{array}$ & $\begin{array}{l}\text { 山 } \\
\text { 足 } \\
\text { 文 }\end{array}$ & 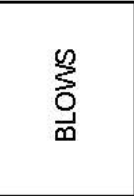 & 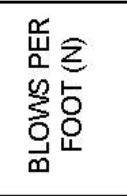 \\
\hline \begin{tabular}{|c}
0 \\
-5 \\
-5 \\
-10 \\
- \\
- \\
\end{tabular} & 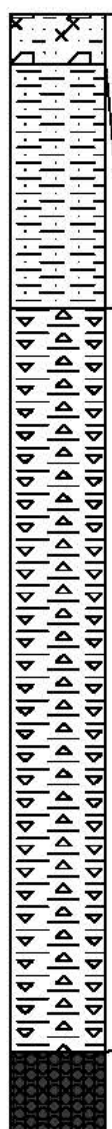 & $\begin{array}{l}\text { POORLY GRADED GRAVEL WITH SIL } \\
\text { AND SAND FILL (GP-GM-FILL): Browni } \\
\text { gray, slightly moist to moist, medium der } \\
\text { to dense, with fine to coarse-grained sar } \\
\text { and 2-inch-minus gravel. } \\
\text { SILT WITH SAND (ML): Brown, slightly } \\
\text { moist, hard, with fine-grained sand. } \\
\\
\text { SILT WITH GRAVEL (ML): Brown, slight } \\
\text { moist, hard, with fine-grained sand and } \\
\text { inch-minus basalt gravel. } \\
\text { - Weak calcium carbonate cementation } \\
\text { noted in top of layer. } \\
\text {-Gravel content varied throughout. }\end{array}$ & & & & & & $\mathbf{D}$ & $\begin{array}{l}6 / 19 / 38 \\
14 / 22 / 17 \\
8 / 8 / 13 \\
50 \text { for } 4 "\end{array}$ & 300 \\
\hline
\end{tabular}




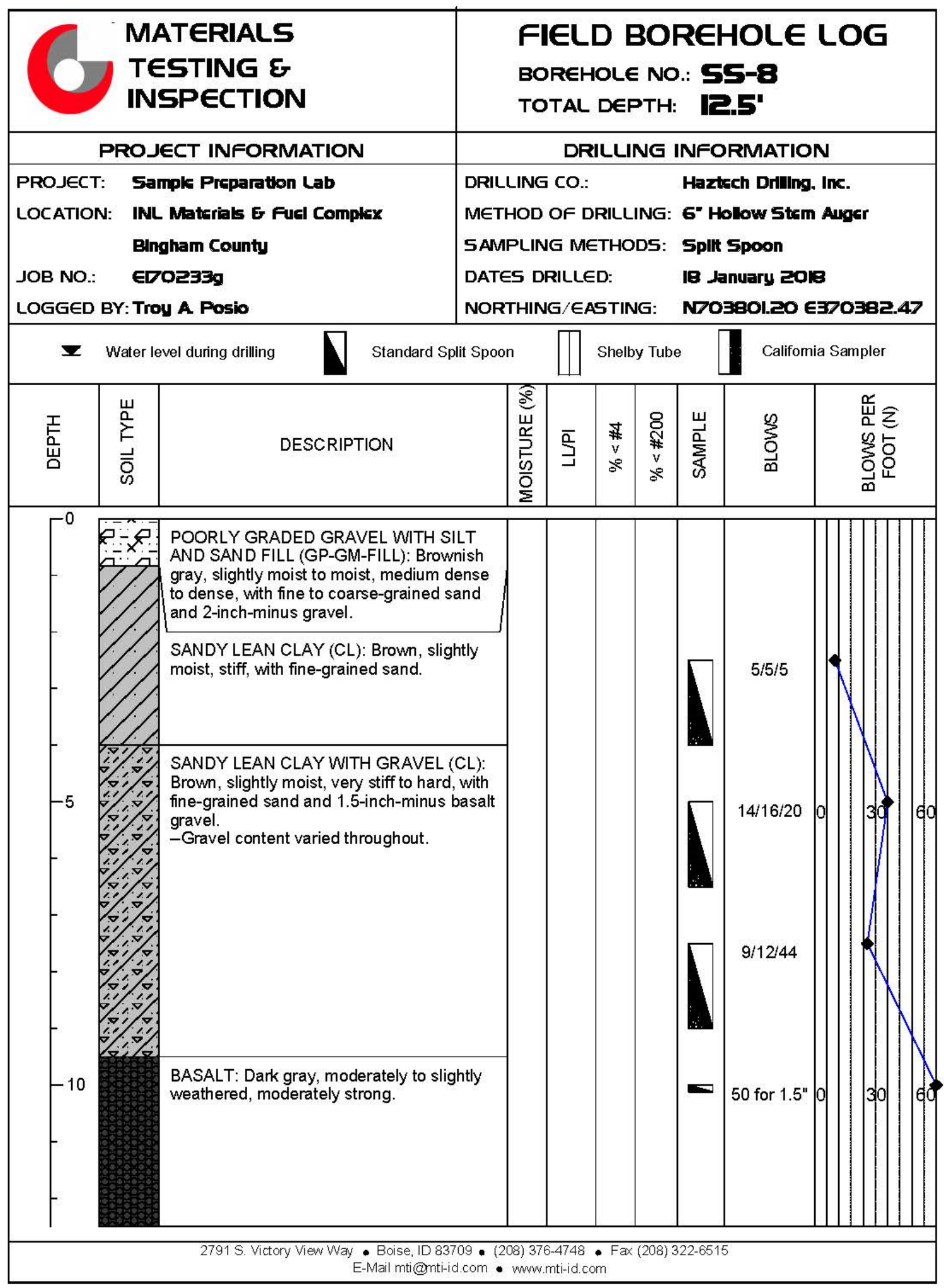




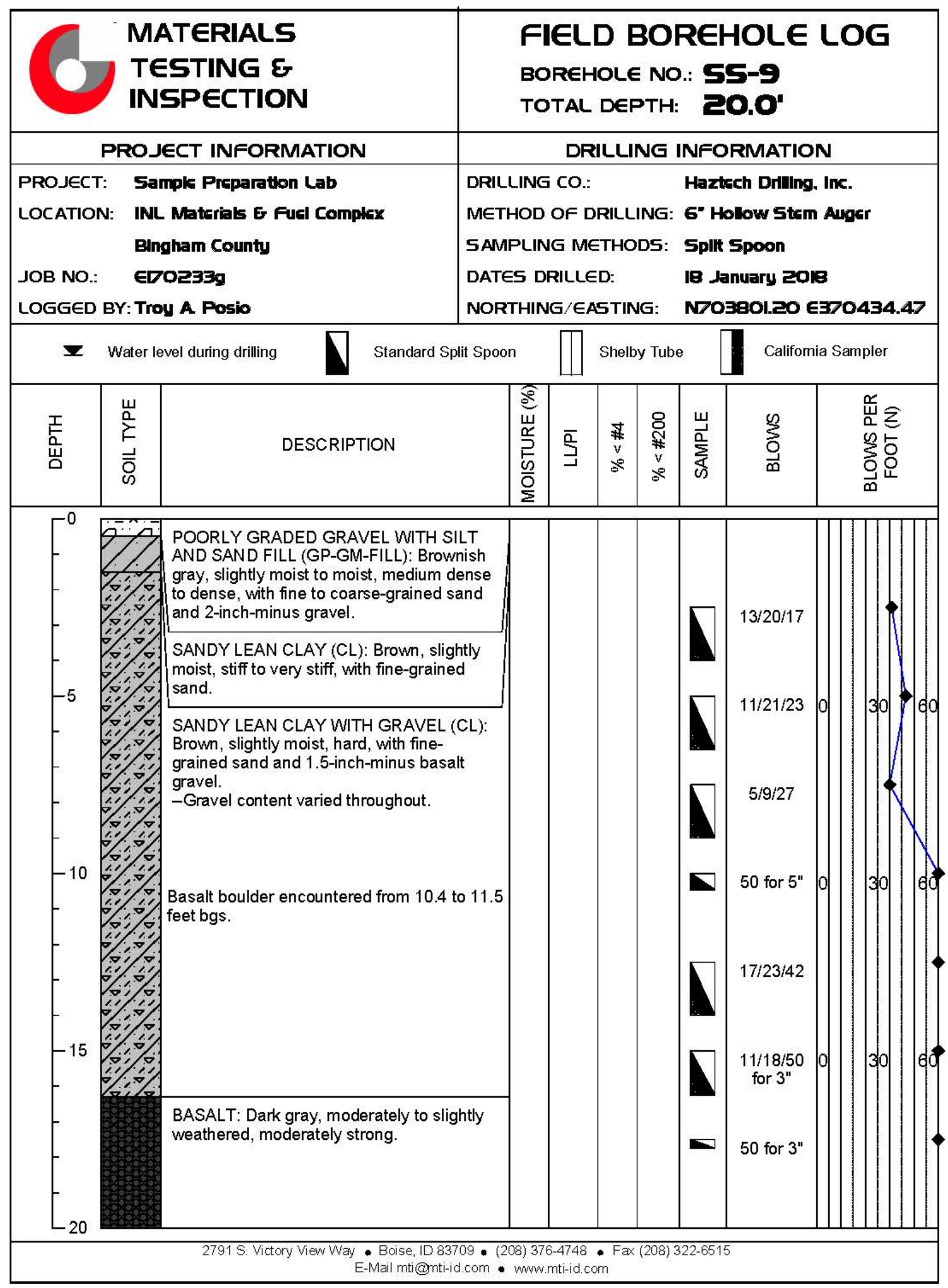




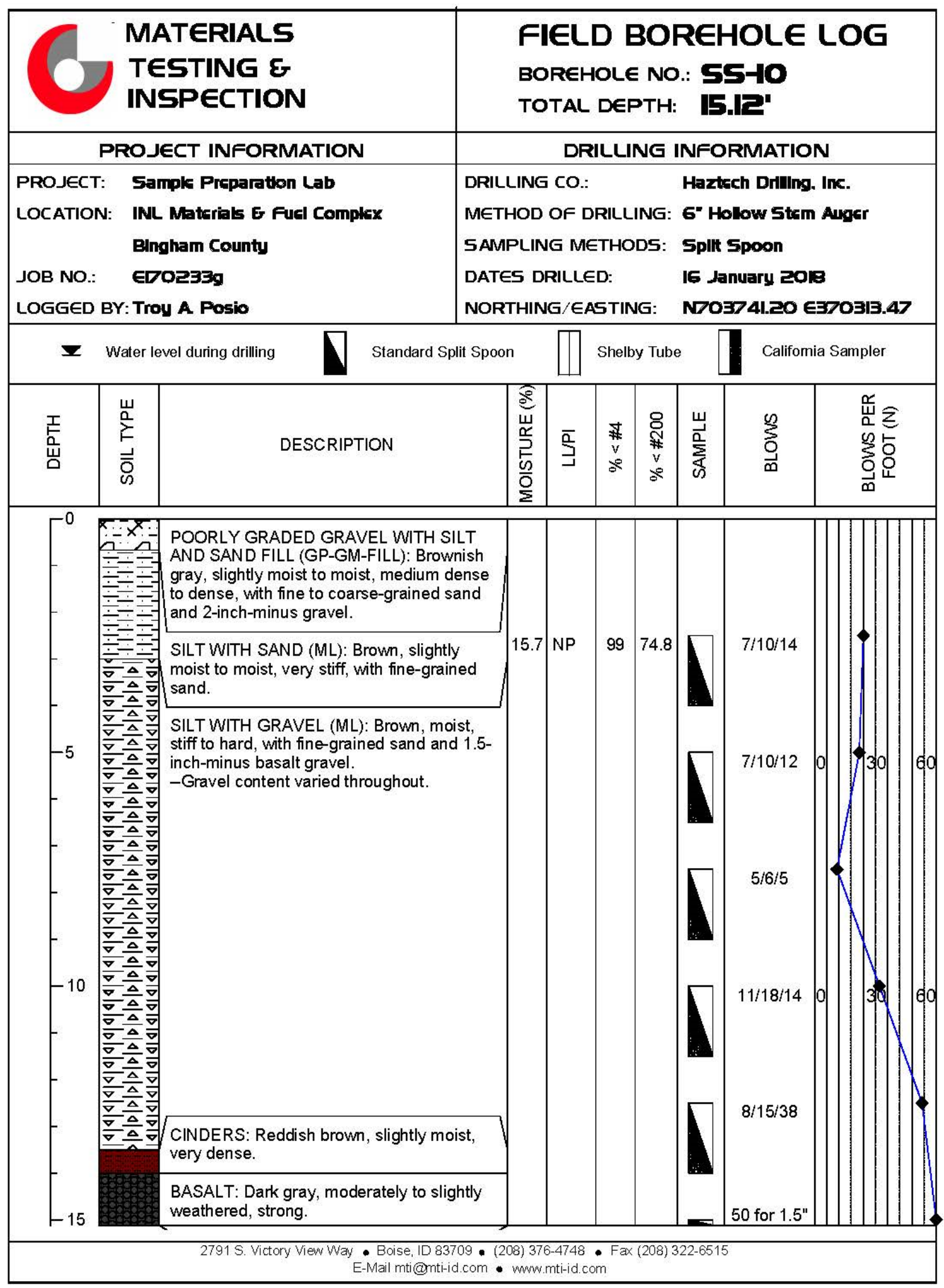




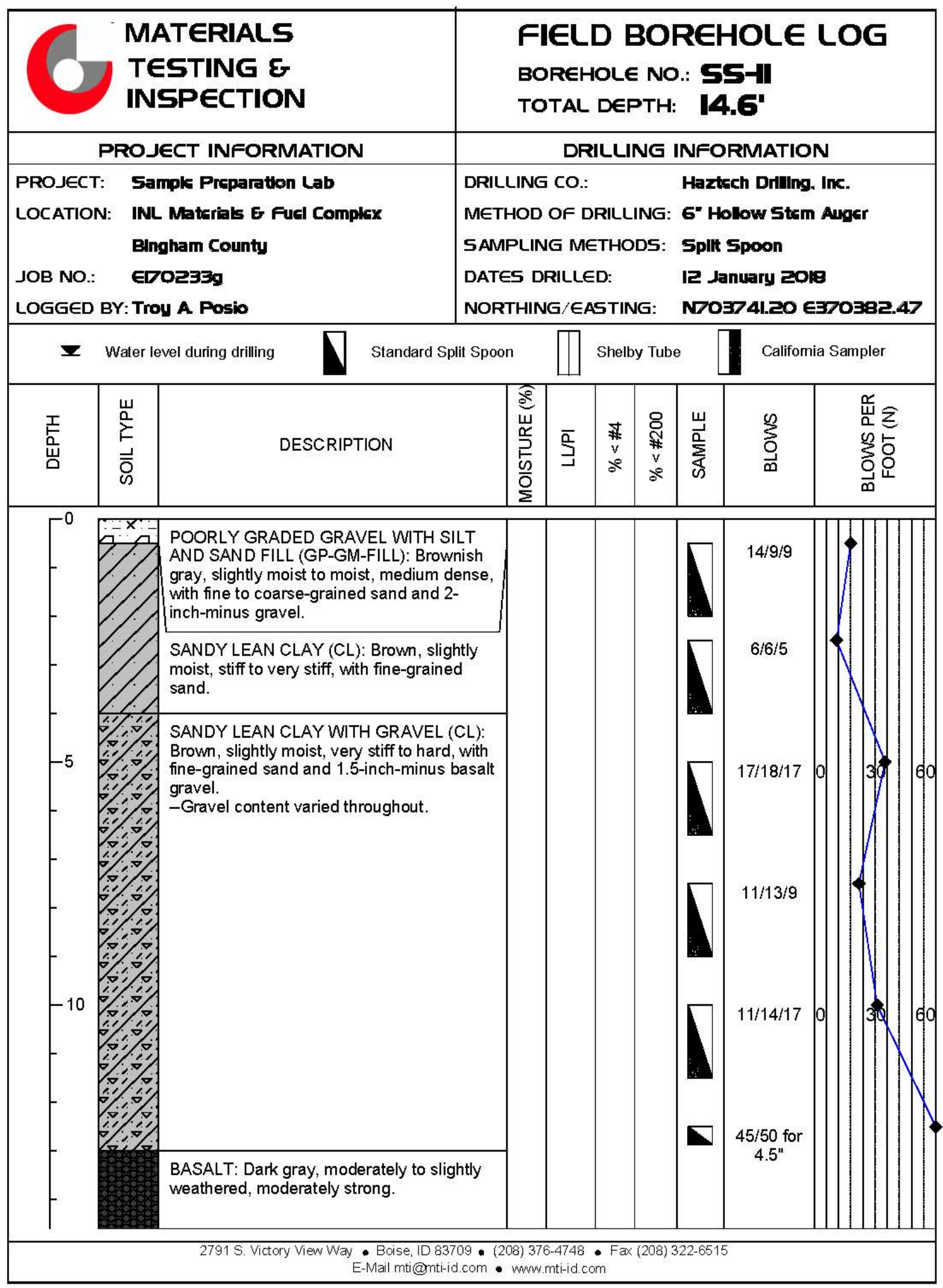




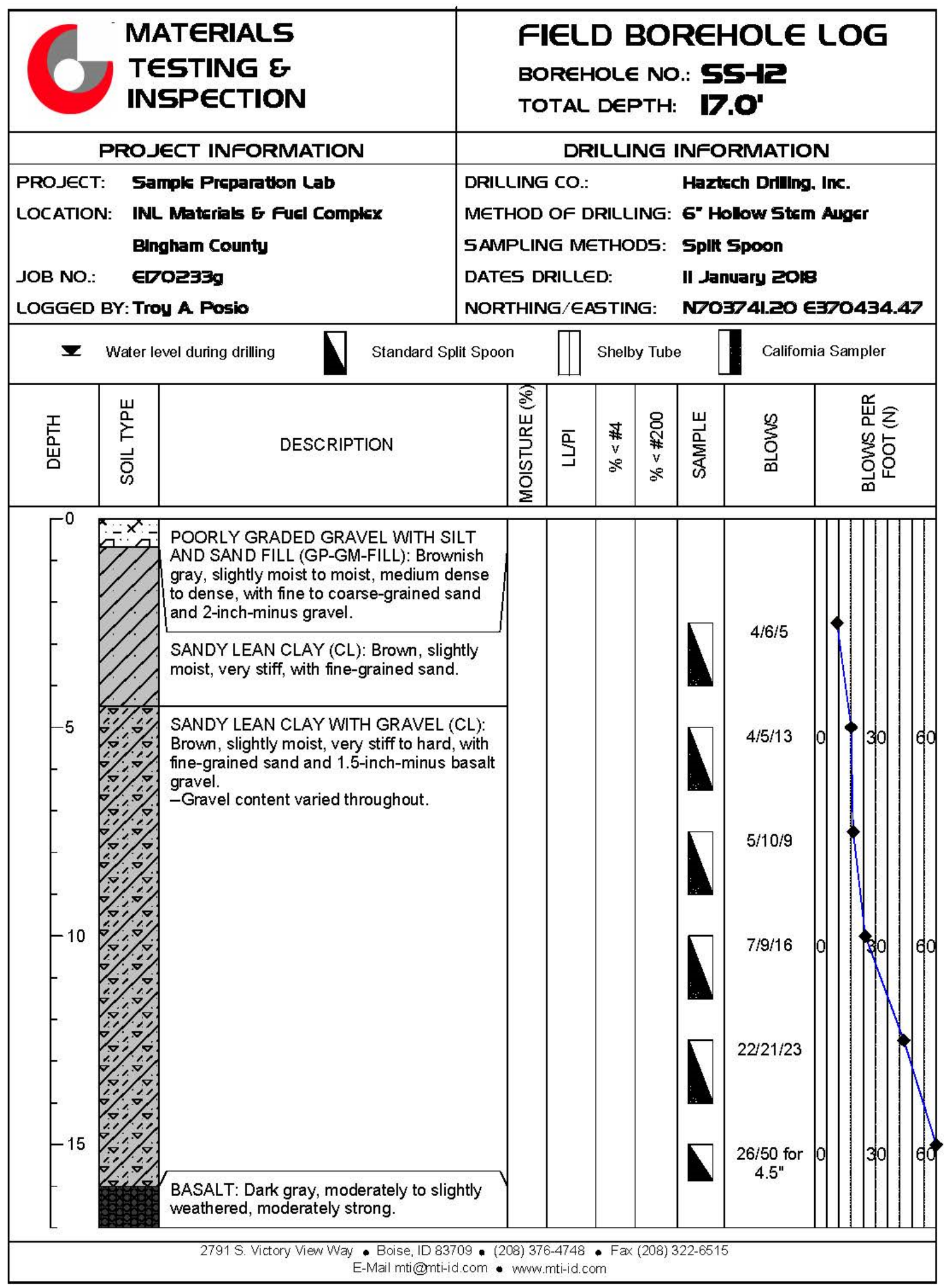




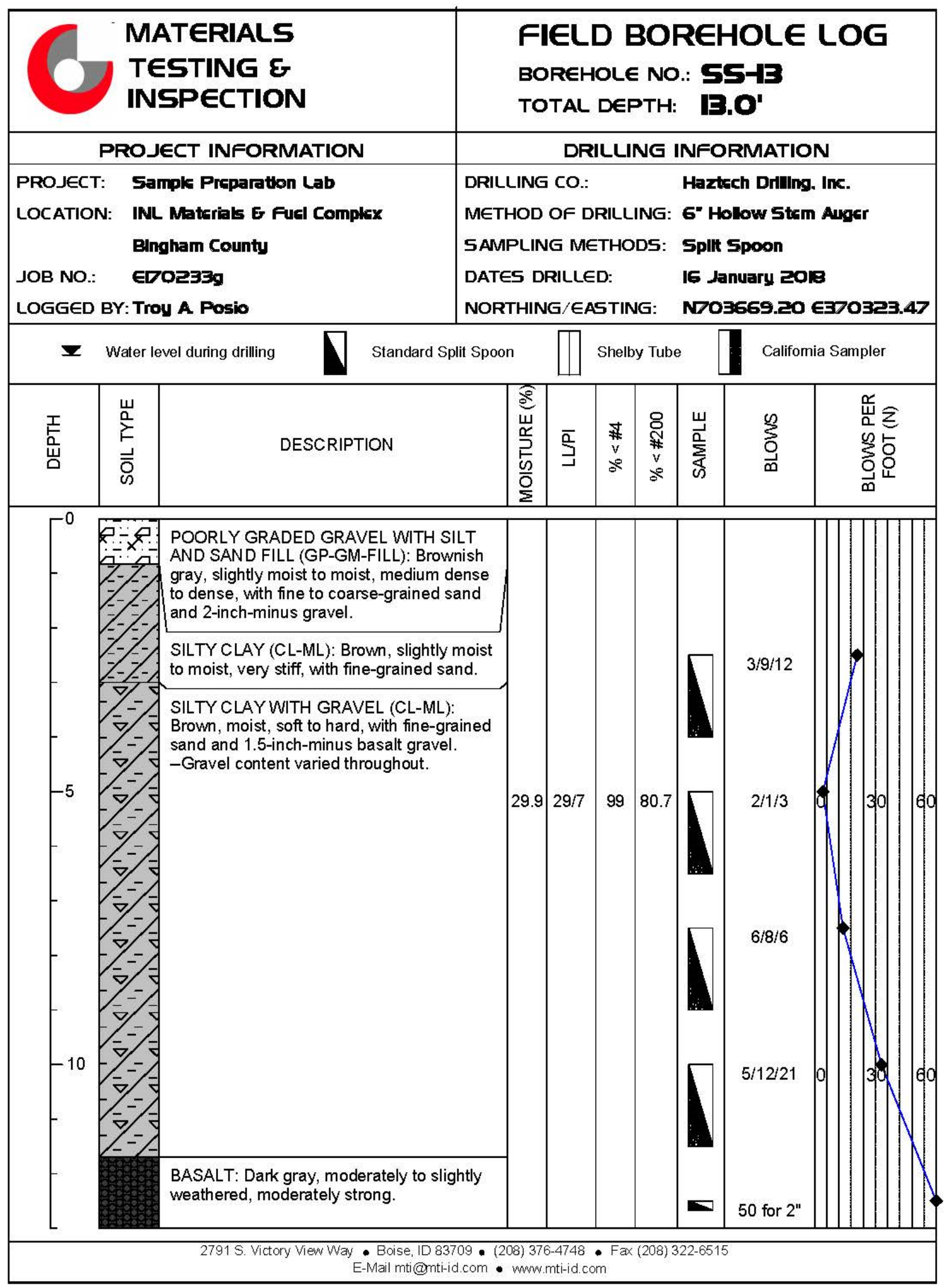




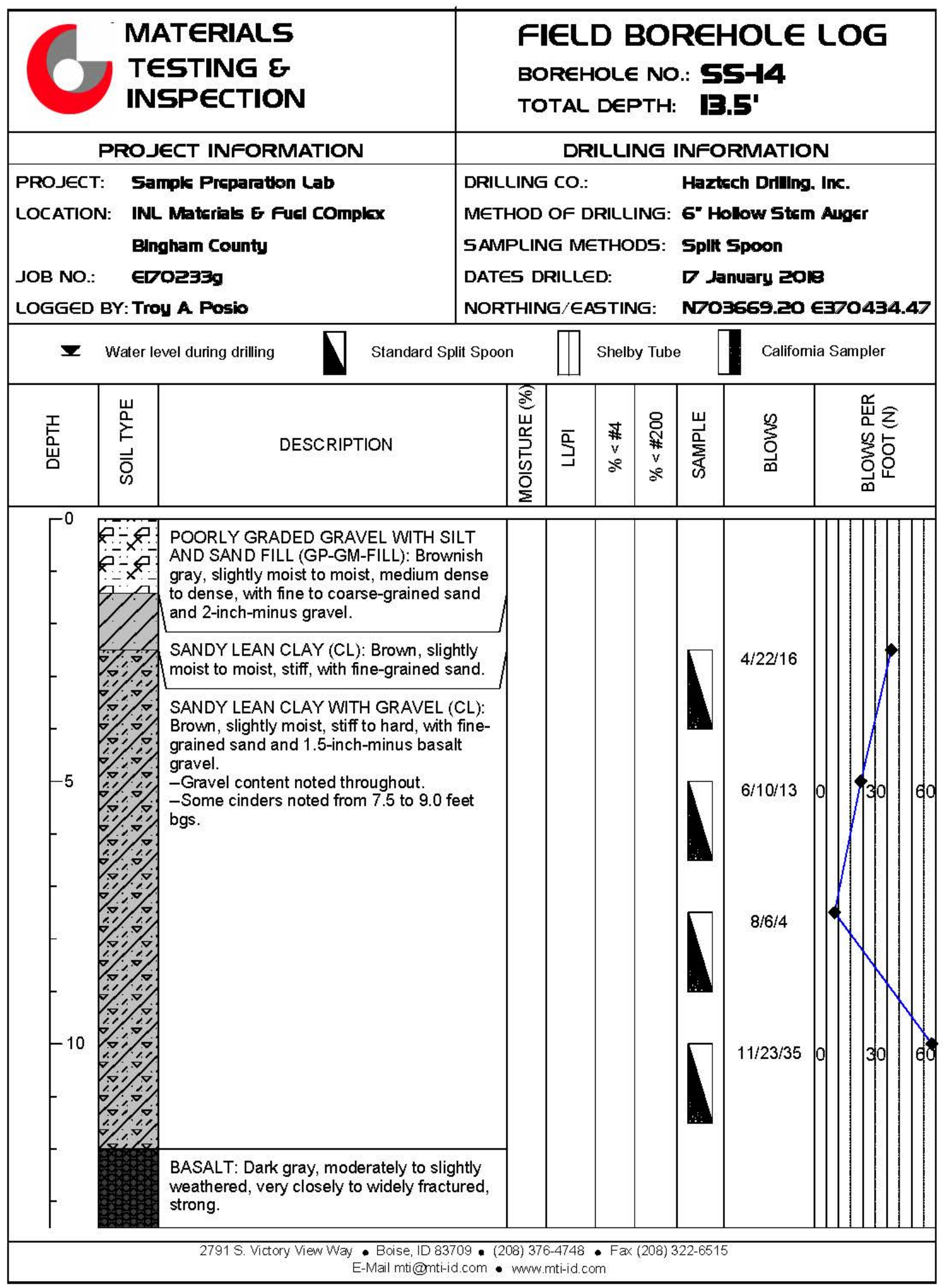




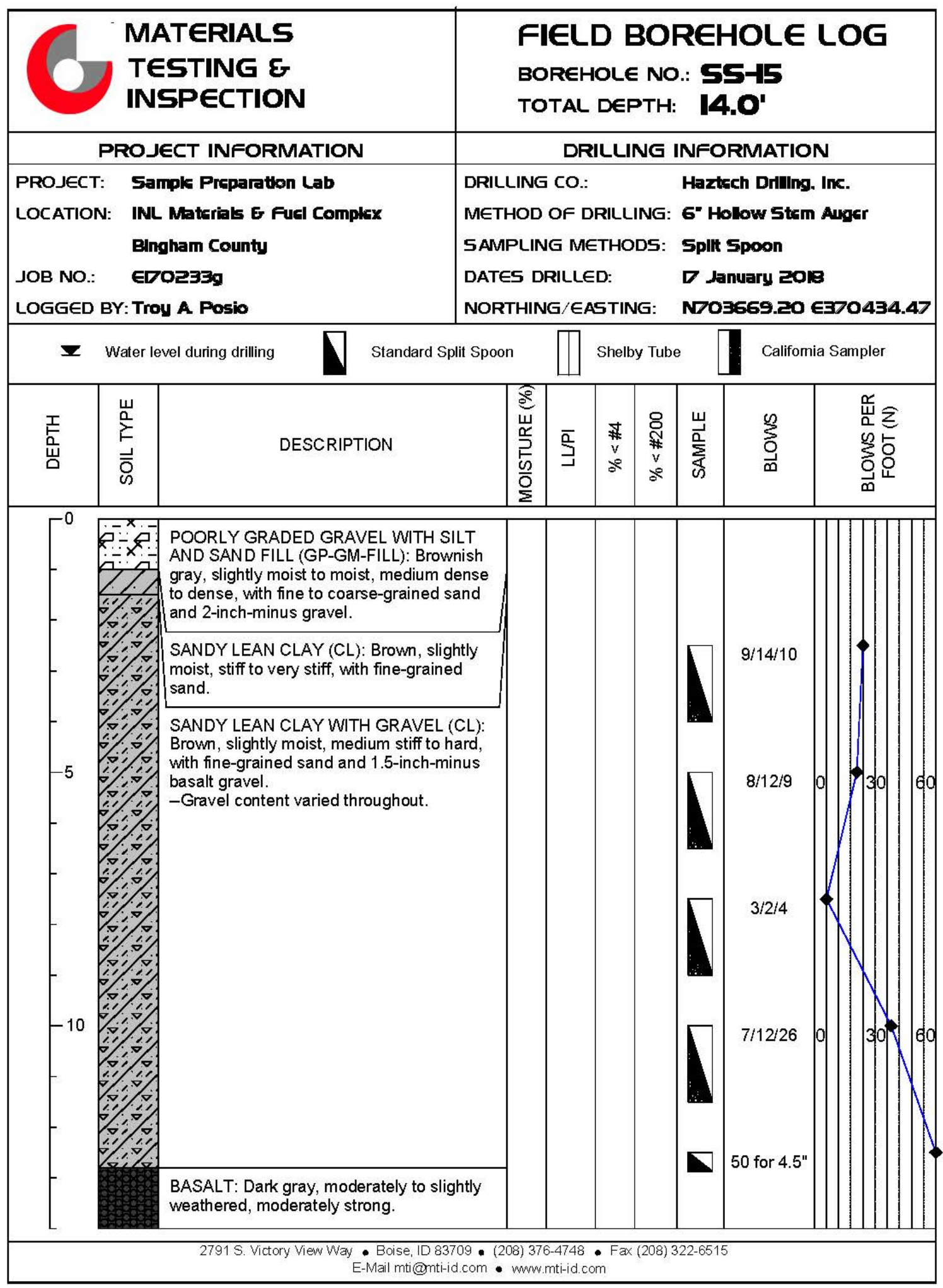




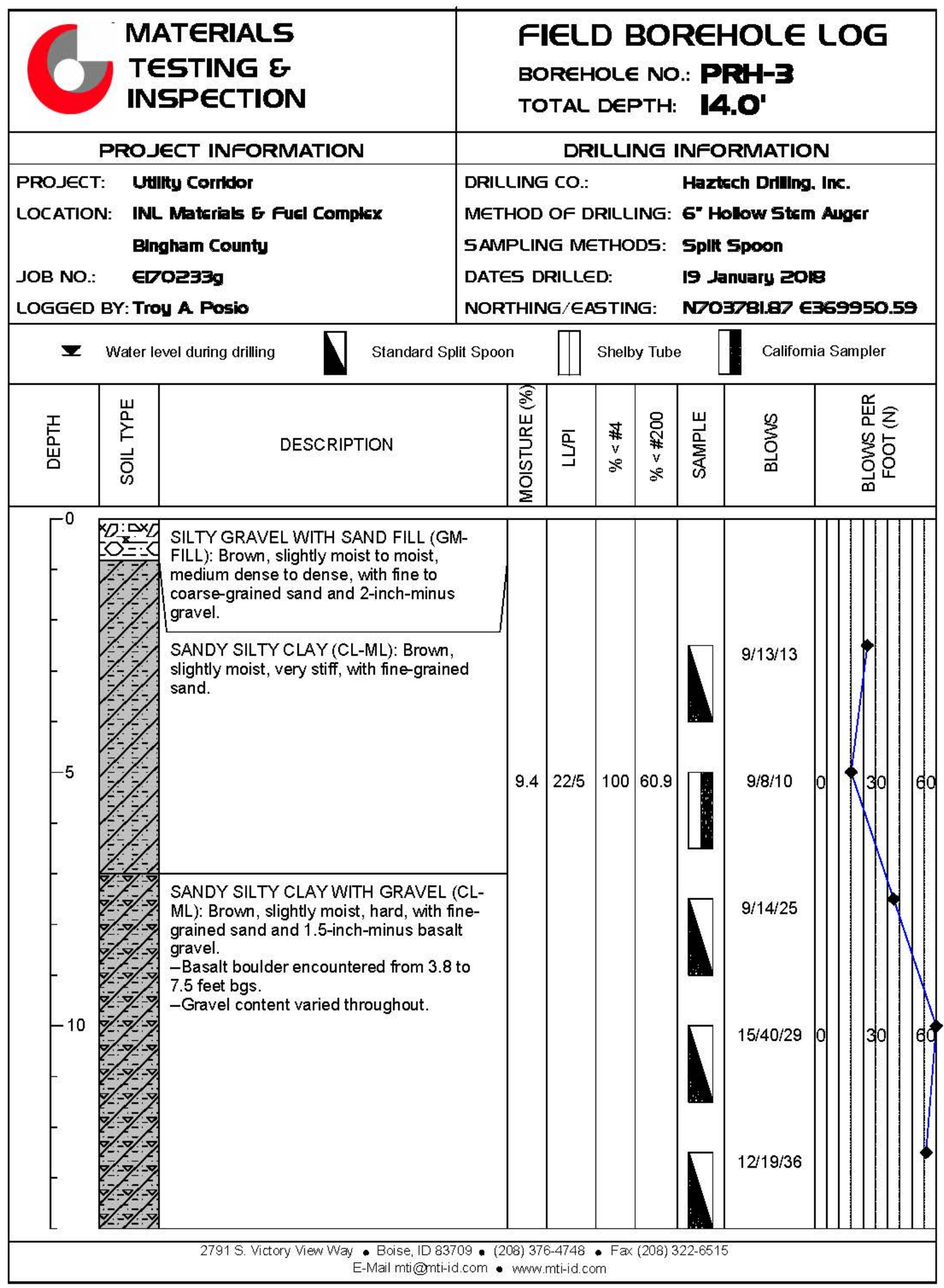




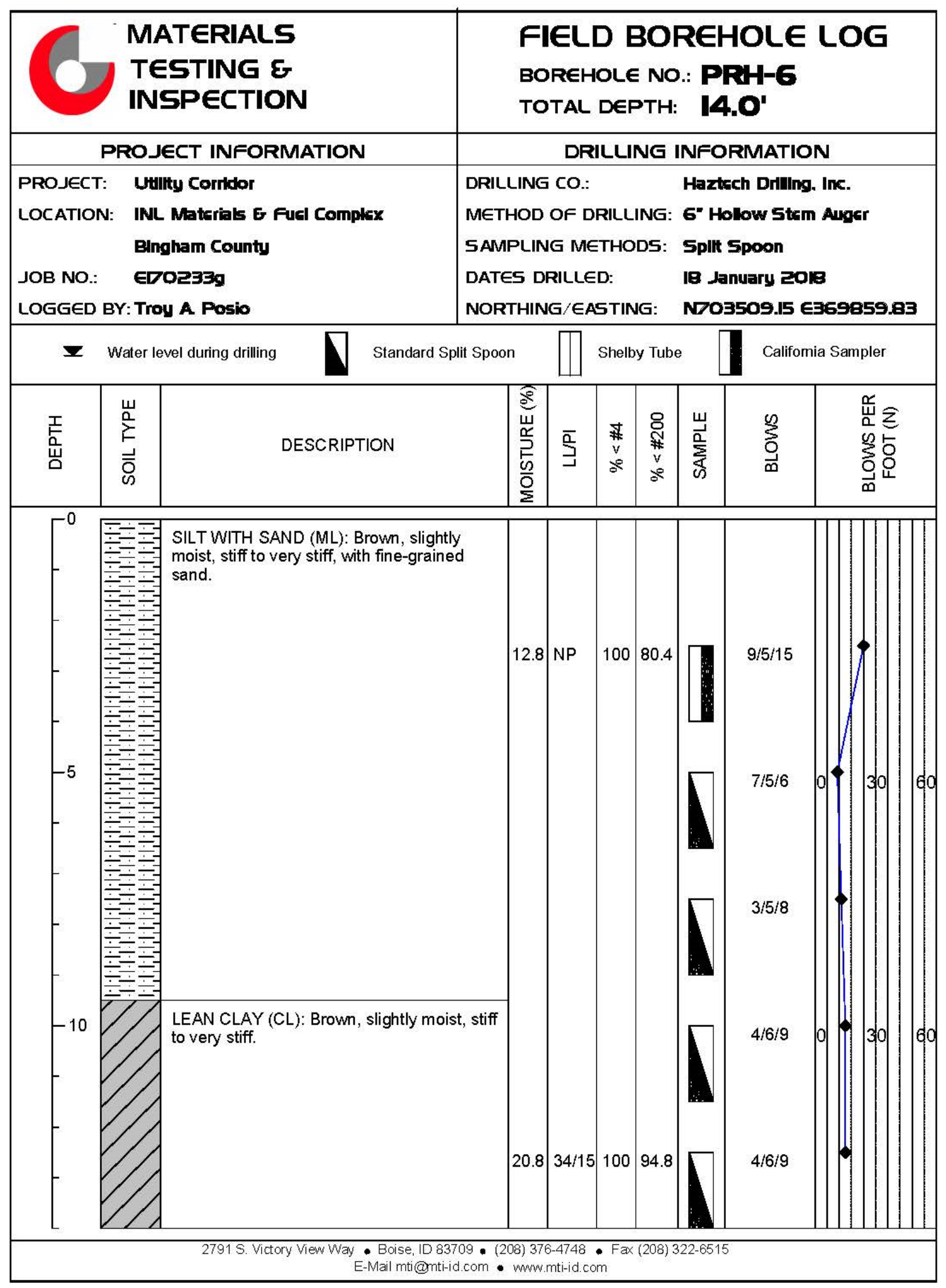


Utility Corridor SoIL Probe Depth to Bedrock

\begin{tabular}{|c|c|}
\hline Boring & Depth to Bedrock \\
\hline PRH-1 & Not encountered to 14.0 feet bgs \\
\hline PRH-2 & 13.5 feet bgs \\
\hline PRH-3 & Not encountered to 14.0 feet bgs \\
\hline PRH-4 & Not encountered to 14.0 feet bgs \\
\hline PRH-5 & 9.0 feet bgs \\
\hline PRH-6 & Not encountered to 14.0 feet bgs \\
\hline PRH-7 & 7.5 feet bgs \\
\hline PRH-8 & 2.0 feet bgs \\
\hline PRH-9 & 1.3 feet bgs \\
\hline PRH-10 & 2.5 feet bgs \\
\hline PRH-11 & 10.5 feet bgs \\
\hline PRH-12 & 9.5 feet bgs \\
\hline PRH-13 & 2.5 feet bgs \\
\hline PRH-14 & 4.0 feet bgs \\
\hline PRH-15 & \\
\hline
\end{tabular}




\section{LABORATORY Test Results}

All laboratory test results have been reviewed and approved by MTI corporate quality manager Brandon Huff to ensure that all tests were performed in accordance with applicable test standards.

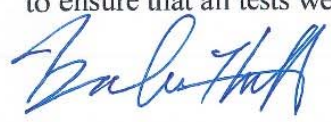

Brandon Huff

Corporate Quality Manager

ROCK CORE COMPRESSIVE STRENGTH

\begin{tabular}{|c|c|c|c|c|c|c|}
\hline $\begin{array}{c}\text { Lab Test } \\
\text { Location/Depth }\end{array}$ & $\begin{array}{c}\text { Cylinder } \\
\text { Diameter }\end{array}$ & $\begin{array}{c}\text { Cylinder } \\
\text { Height }\end{array}$ & $\begin{array}{c}\text { Test } \\
\text { Date }\end{array}$ & $\begin{array}{c}\text { Load } \\
\text { Failure }\end{array}$ & $\mathbf{6}_{\mathbf{u}}{ }^{*}$ & $\boldsymbol{\sigma}_{\mathbf{u}}$ \\
\hline- & (in) & (in) & - & (lbs) & (psi) & (tsf) \\
\hline SB-1 17.0' & 2.39 & 4.78 & $1 / 23 / 18$ & 16,615 & 3,700 & 266.4 \\
\hline SB-1 24.0' & 2.38 & 4.81 & $1 / 23 / 18$ & 20,645 & 4,640 & 334.1 \\
\hline SB-2 15.0' & 2.38 & 4.68 & $1 / 23 / 18$ & 15,560 & 3,500 & 252.0 \\
\hline SB-2 16.0' & 2.39 & 4.72 & $1 / 23 / 18$ & 29,050 & 6,470 & 465.8 \\
\hline SB-2 24.5' & 2.39 & 4.83 & $1 / 23 / 18$ & 18,425 & 4,100 & 295.2 \\
\hline SB-3 13.5' & 2.39 & 4.80 & $1 / 23 / 18$ & 18,520 & 4,120 & 296.6 \\
\hline SB-3 23.5' & 2.39 & 4.70 & $1 / 23 / 18$ & 22,075 & 4,920 & 354.2 \\
\hline SB-4 15.0' & 2.38 & 4.72 & $1 / 23 / 18$ & 56,755 & 12,750 & 918.0 \\
\hline SB-4 20.0' & 2.39 & 4.79 & $1 / 23 / 18$ & 25,510 & 5,680 & 409.0 \\
\hline SB-4 25.0' & 2.39 & 4.69 & $1 / 23 / 18$ & 13,985 & 3,110 & 223.9 \\
\hline
\end{tabular}

SIEVE AND ATTERBERG

\begin{tabular}{|c|c|c|c|c|c|c|c|c|}
\hline \multirow{2}{*}{$\begin{array}{c}\text { Lab Test } \\
\text { Location/depth } \\
-\end{array}$} & \multirow{2}{*}{$\begin{array}{c}\mathbf{M} \\
\% \\
\end{array}$} & \multirow{2}{*}{$\begin{array}{c}\mathbf{L L} \\
-\end{array}$} & \multirow{2}{*}{$\begin{array}{c}\text { PI } \\
- \\
\end{array}$} & \multicolumn{5}{|c|}{ Sieve Analysis (\% passing) } \\
\hline & & & & $\# 4$ & $\# 10$ & $\# 40$ & $\# 100$ & $\# 200$ \\
\hline SB-1 $2.5^{\prime}$ & 12.8 & 25 & 9 & 99 & 99 & 96 & 76 & 62.9 \\
\hline SP-1 2.0 & 17.2 & - & - & 99 & 97 & 93 & 73 & 55.9 \\
\hline SP-5 2.5 & 12.9 & - & - & 99 & 96 & 90 & 68 & 52.5 \\
\hline SP-12 0.8' & 17.2 & 23 & 8 & 100 & 99 & 97 & 81 & 64.8 \\
\hline SP-13 17.5' & 23.3 & 31 & 15 & 100 & 99 & 99 & 96 & 91.5 \\
\hline SS-10 2.5 & 15.7 & - & - & 99 & 98 & 96 & 87 & 74.8 \\
\hline SS-13 5.0' & 29.9 & 29 & 7 & 99 & 99 & 97 & 91 & 80.7 \\
\hline PRH-3 5.0' & 9.4 & 22 & 5 & 100 & 100 & 97 & 81 & 60.9 \\
\hline PRH-6 2.5' & 12.8 & - & - & 100 & 100 & 98 & 91 & 80.4 \\
\hline PRH-6 12.5, & 20.8 & 34 & 15 & 100 & 100 & 99 & 98 & 94.8 \\
\hline
\end{tabular}


HYDROMETER

\begin{tabular}{|c|c|c|c|c|}
\hline $\begin{array}{c}\text { Lab Test } \\
\text { Location/Depth }\end{array}$ & \multicolumn{4}{|c|}{ Hydrometer (\%) } \\
\hline- & Sand & Silt & Clay & Colloids \\
\hline PRH-3 5.0' & 39.1 & 60.2 & 0.6 & 0.1 \\
\hline PRH-6 2.5' & 19.6 & 71.2 & 5.0 & 4.2 \\
\hline PRH-6 5.0 & 5.2 & 89.9 & 3.5 & 1.4 \\
\hline
\end{tabular}

TUBE DENSITY

\begin{tabular}{|c|c|}
\hline $\begin{array}{c}\text { Lab Test } \\
\text { Location/Depth }\end{array}$ & Dry Density \\
\hline- & lbs/ft ${ }^{3}$ \\
\hline PRH-3 5.0 & 108.00 \\
\hline PRH-6 2.5' & 91.77 \\
\hline
\end{tabular}

Testing standards for the above listed laboratory tests can be found in the Laboratory Testing Program section of this report. 


\section{CBR Laboratory Test Data}

\begin{tabular}{|c|c|}
\hline Source and Description: & SP-1:2.0' Clay. Assumed Maximum Density and Moisture. \\
\hline Date Obtained: & Janurary 24,2018 \\
\hline Sample ID: & $18-7060$ \\
\hline Soak Period \& Swell: & 96 Hours and $1.0 \%$ \\
\hline Sampling and Preparation: & $\begin{aligned} \text { ASTM D75: } & \mathrm{X} \\
\text { ASTM D421: } & \mathrm{X}\end{aligned}$ \\
\hline Test Standard: & ASTMD1883: $\mathrm{X}$ \\
\hline Sample Compaction: & $\begin{aligned} \text { ASTM D 698: } & \text { X } \\
\text { ASTM D 1557: } & \end{aligned}$ \\
\hline Sample Condition: & Soaked: $\mathrm{X}$ \\
\hline
\end{tabular}

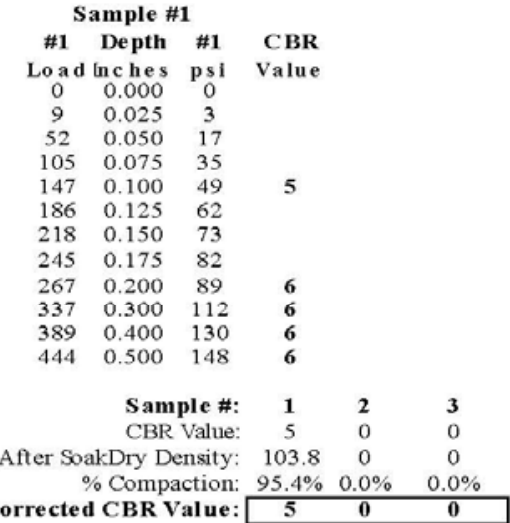

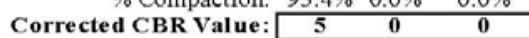

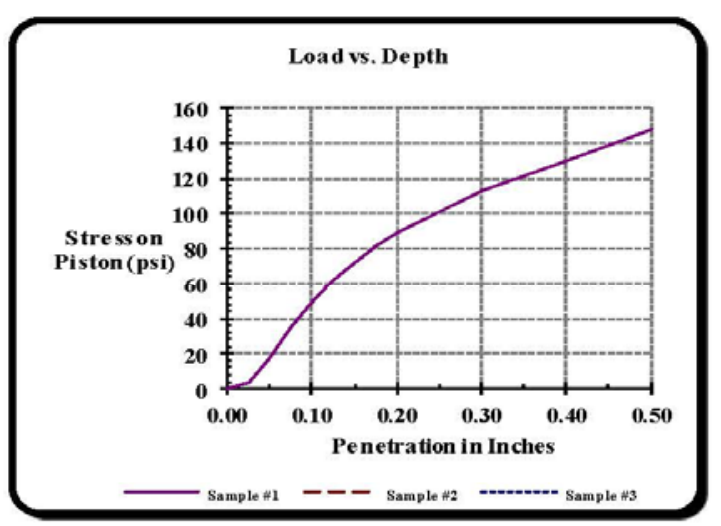

Before Soak Maximum Dry Density: 108.8 Moisture Content Before Compaction: 12.6 Moisture Content After Compaction: 12.6 Moisture Content Top 1 Inch: 24.1 \% Passing 3/4": 100 Surcharge Amount (lb): 10.0

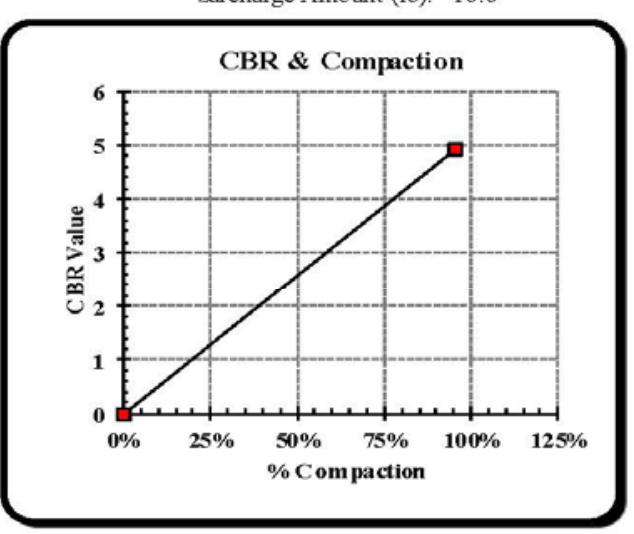




\section{CBR Laboratory Test Data}

\begin{tabular}{|r|lrl|}
\hline Source and Description: & SP-2:2.0' Clay. Assumed Maximum Density and Moisture. \\
\hline Date Obtained: & Janurary 24, 2018 & & \\
\hline Sample ID: & $18-7061$ & & \\
\hline Soak Period \& Swell: & 96 Hours and 1.1\% & \\
\hline Sampling and Preparation: & ASTM D75: X & AASHTO T2: \\
& ASTM D421: X & AASHTO T87: \\
\hline Test Standard: & ASTM D 1883: X & AASHTO T193: & \\
\hline Sample Compaction: & ASTM D 698: X & AASHTO T 99: & Method \\
& ASTM D 1557: & AASHTO T 180: \\
\hline Sample Condition: & Soaked: & X & Unsoaked: \\
\hline
\end{tabular}

Sample \#1

\#1 Depth \#1 CBR

Load Inches psi Value

00.000

$\begin{array}{ll}53 & 0.025\end{array}$

$\begin{array}{lll}136 & 0.075 & 32\end{array}$

$\begin{array}{lll}171 & 0.100 & 57\end{array}$

$200 \quad 0.125 \quad 67$

$\begin{array}{lll}224 & 0.150 & 75\end{array}$

$\begin{array}{lll}245 & 0.175 & 82\end{array}$

$\begin{array}{lll}265 & 0.200 \quad 88\end{array}$

$\begin{array}{lll}322 & 0.300 & 107\end{array}$

$\begin{array}{lll}361 & 0.400 & 120\end{array}$

$\begin{array}{lll}401 & 0.500 \quad 134\end{array}$

S ample \#:

CBR Value:

After SoakDry Density: 105.5

$\begin{array}{llll}\% \text { Compaction: } 96.3 \% & 0.0 \% & 0.0 \%\end{array}$

Corrected CBR Value: \begin{tabular}{cccc}
$\mathbf{6}$ & $\mathbf{0}$ & $\mathbf{0}$ \\
\cline { 2 - 3 }
\end{tabular}

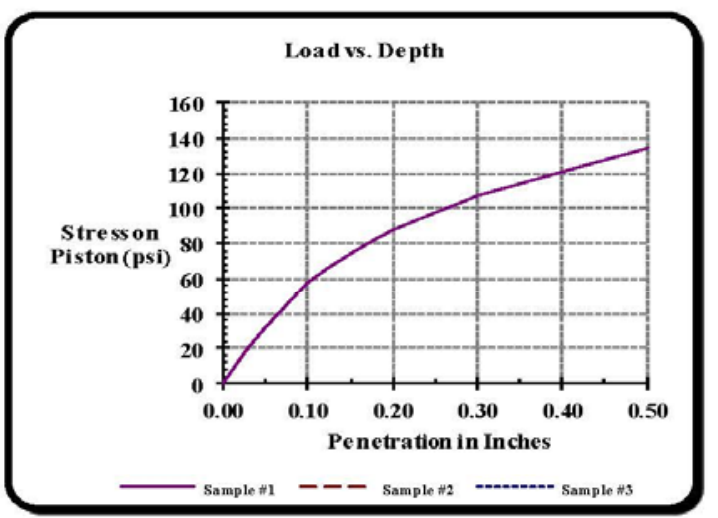

Before Soak Maximum Dry Density: 109.6 Moisture Content Before Compaction: 12.3

Moisture Content After Compaction: 12.3 Moisture Content T op 1 Inch: 22.9 $\%$ Passing 3/4": 100 Surcharge Amount (lb): 10.0

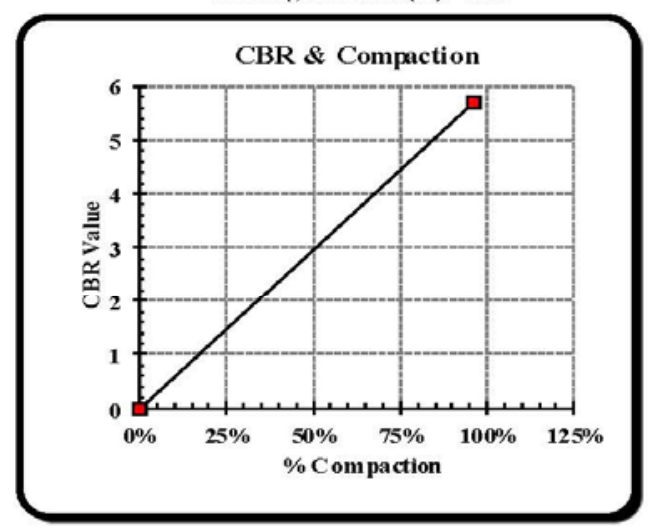




\section{LABORATORY COMPACTION CHARACTERISTICS OF SOIL}

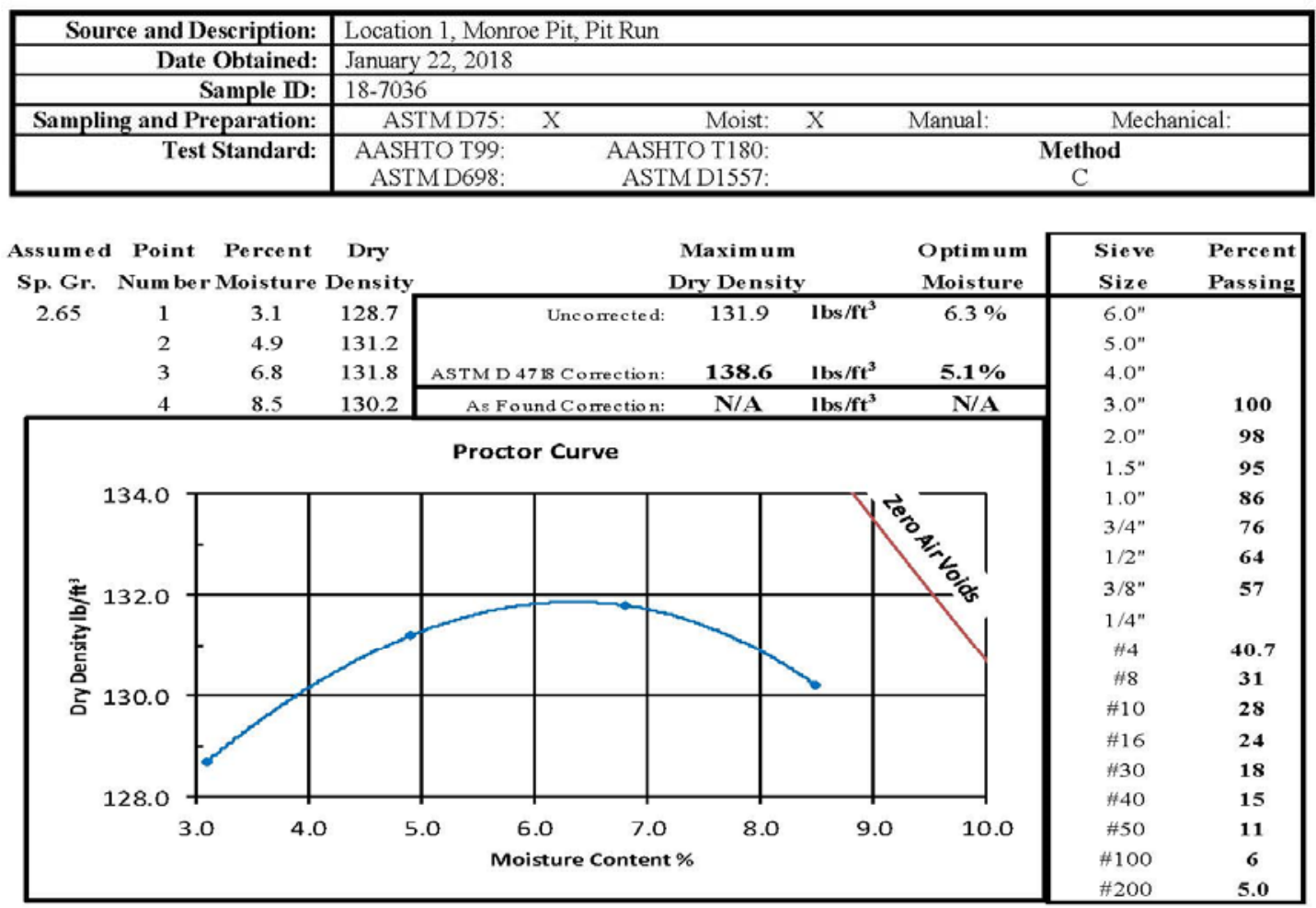

Note: ASTM D698 and D1557 valid with up to 5\% Oversize Particles; correctable up to $30 \%$ via ASTM D 4718 and invalid for Oversized Particles greater than $30 \%$ retained on the $3 / 4$ inch screen. 


\section{LABORATORY COMPACTION CHARACTERISTICS OF SOIL}

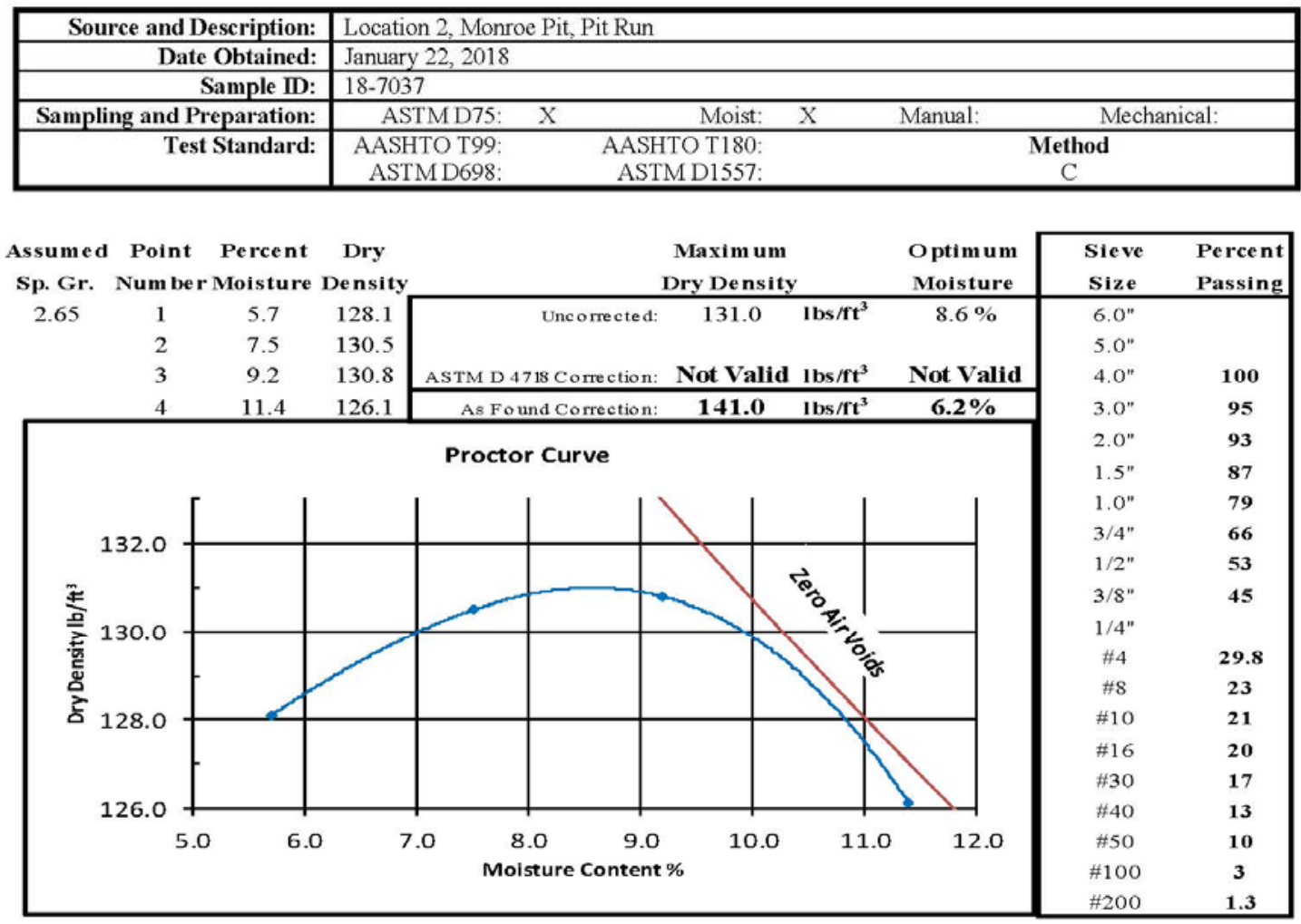

Note: ASTM D698 and D1557 valid with up to 5\% Oversize Particles; correctable up to 30\% via ASTM D 4718 and invalid for Oversized Particles greater than $30 \%$ retained on the $3 / 4$ inch screen.

Resistivity: 15,800 ohms-cm 


\section{LABORATORY COMPaCtion CHARACTERISTICS OF SOIL}

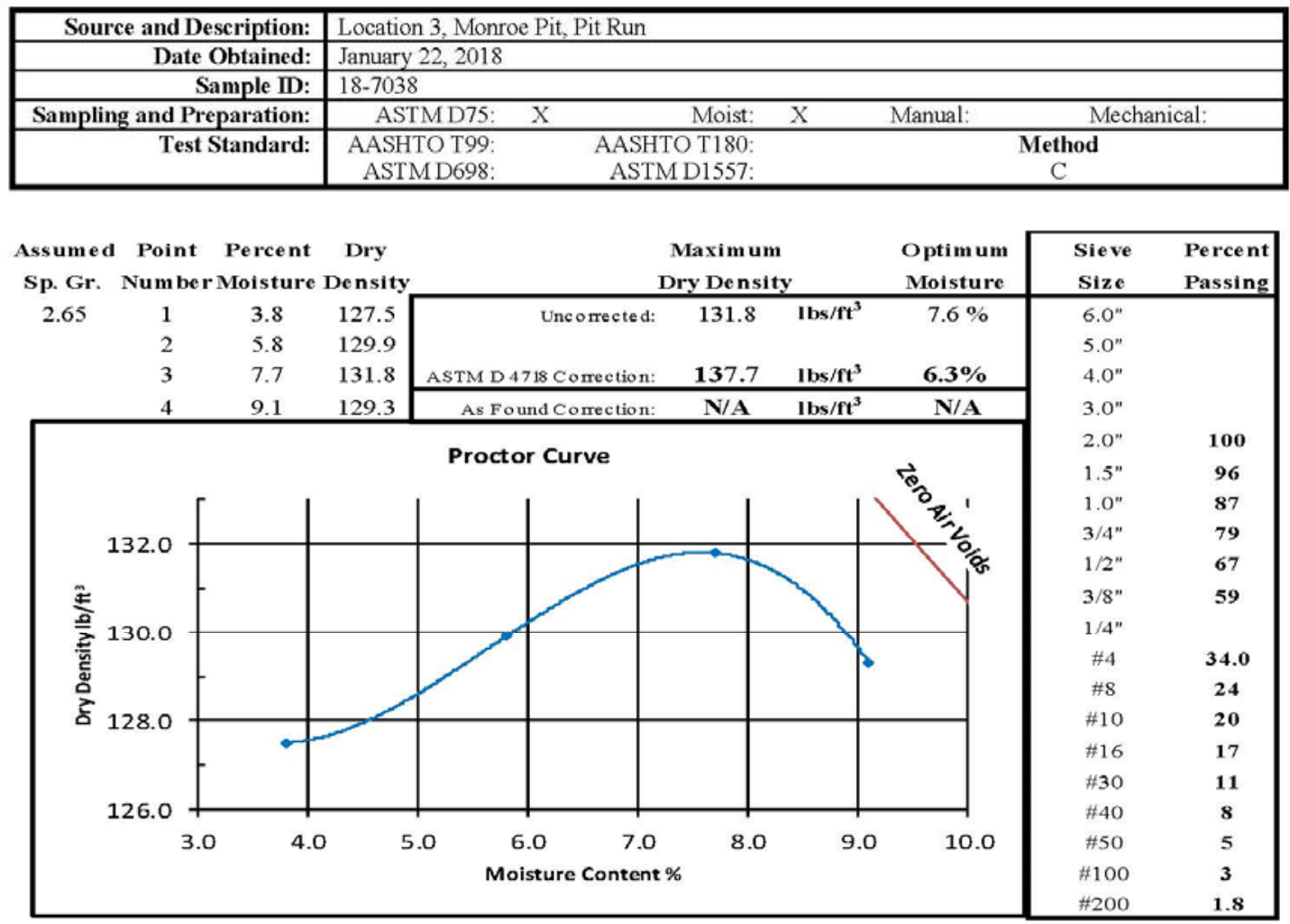

Note: ASTM D698 and D1557 valid with up to 5\% Oversize Particles; correctable up to 30\% via ASTM D 4718 and invalid for Oversized Particles greater than $30 \%$ retained on the $3 / 4$ inch screen.

Resistivity: 15,800 ohms-cm 


\section{Settlement Calculations}

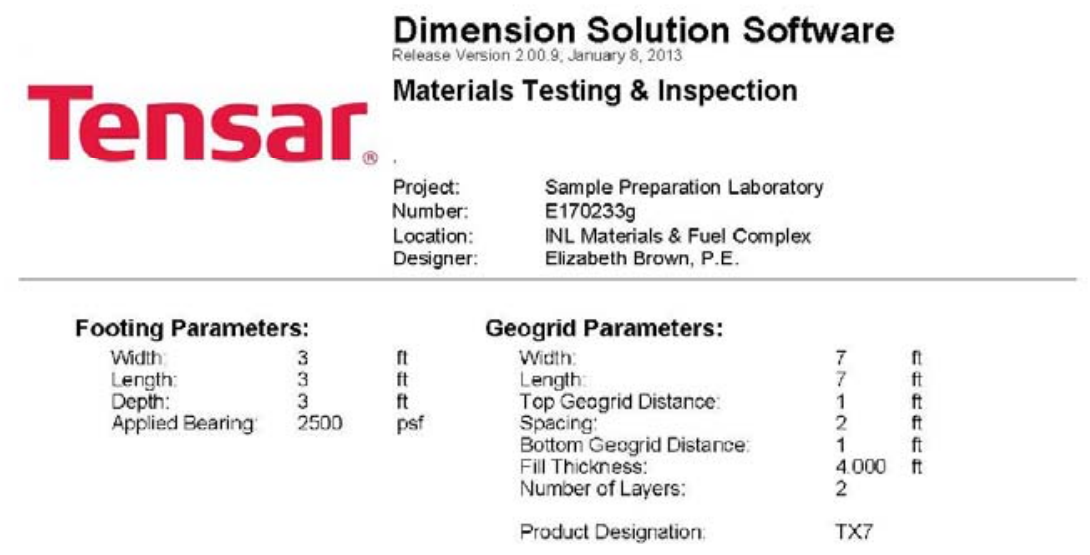

\section{SETTLEMENT}

UNIFORM SOIL INPUT
Foundation Soil Parameters Elastic Modulus: $40 \quad \mathrm{ksf} \quad$ Elastic Modulus: $800 \quad \mathrm{ksf}$ Unit Weight: 125 pef

LAYERED SOIL INPUT, COHESIONLESS AND VARIABLE

\begin{tabular}{|c|c|c|c|c|c|c|c|}
\hline \multicolumn{4}{|c|}{ Reinforced Fill Elastic Modulus: 800} & \multicolumn{4}{|c|}{$\begin{array}{l}\text { S1 - Silts, Sanoy Silts } \\
\text { s2 - Fine-Mecium Sands } \\
\text { \$3 - Coarse Sands } \\
\text { \$4 - Sandy Gravel Gravel }\end{array}$} \\
\hline Layer No & Soil Type & $\begin{array}{l}\text { Thickness } \\
\mathrm{ft}\end{array}$ & $\begin{array}{l}\text { Unit Wgt } \\
\text { pef }\end{array}$ & SPT & OCR & Cofite & $\mathrm{Cr} / \mathrm{Co}$ \\
\hline $\begin{array}{l}1 \\
2 \\
3\end{array}$ & $\begin{array}{l}\text { S1 } \\
\text { S1 } \\
\text { S4 }\end{array}$ & $\begin{array}{l}4 \\
11 \\
10\end{array}$ & $\begin{array}{l}100 \\
105 \\
135\end{array}$ & $\begin{array}{l}4 \\
15 \\
60\end{array}$ & $\begin{array}{l}\text { NA } \\
\text { NA } \\
\text { NA }\end{array}$ & $\begin{array}{l}\text { NA } \\
\text { NA } \\
\text { NA }\end{array}$ & $\begin{array}{l}\text { NA } \\
\text { NA } \\
\text { NA }\end{array}$ \\
\hline \multicolumn{8}{|c|}{ LAYERED COHESIONLESS SOIL OUTPUT } \\
\hline \multicolumn{8}{|c|}{$\begin{array}{l}\text { Estimated Settlement: } \\
\text { Reinforced: } \quad 0.15 \text { in } \\
\text { Unreinforced: } \quad 0.72 \text { in }\end{array}$} \\
\hline
\end{tabular}

Layer 3 was analyzed as a sandy gravel since rock is not an input parameter in the software. 


\section{Settlement Calculations}

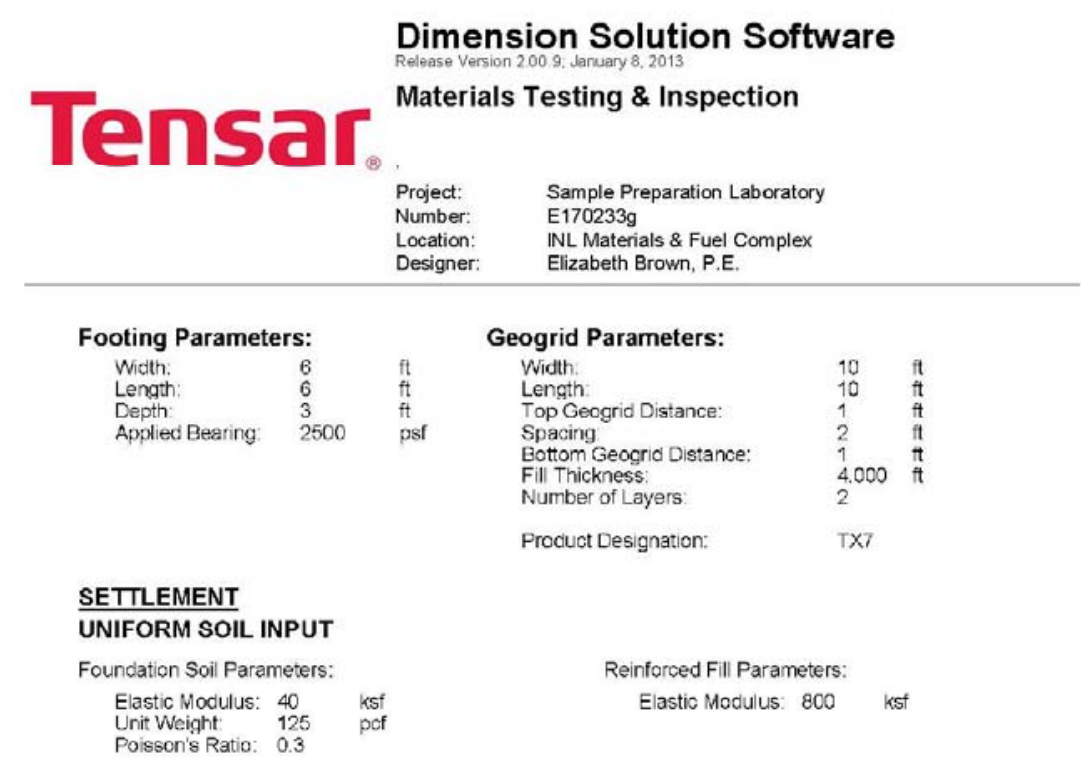

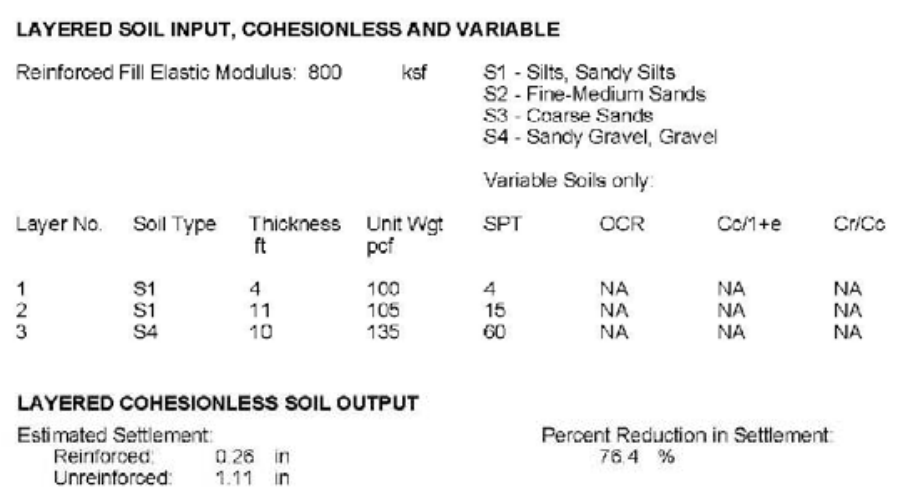

Layer 3 was analyzed as a sandy gravel since rock is not an input parameter in the software. 


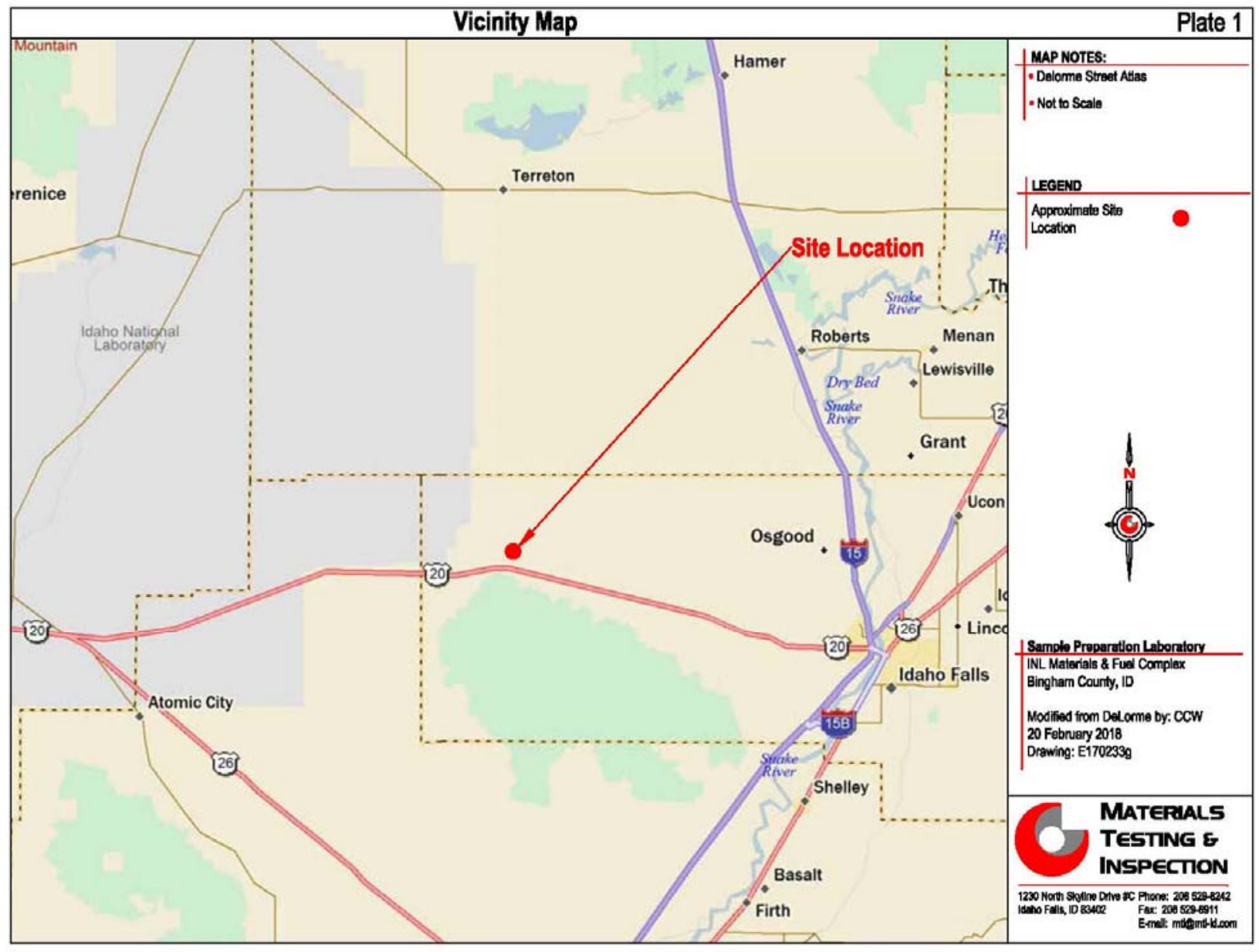




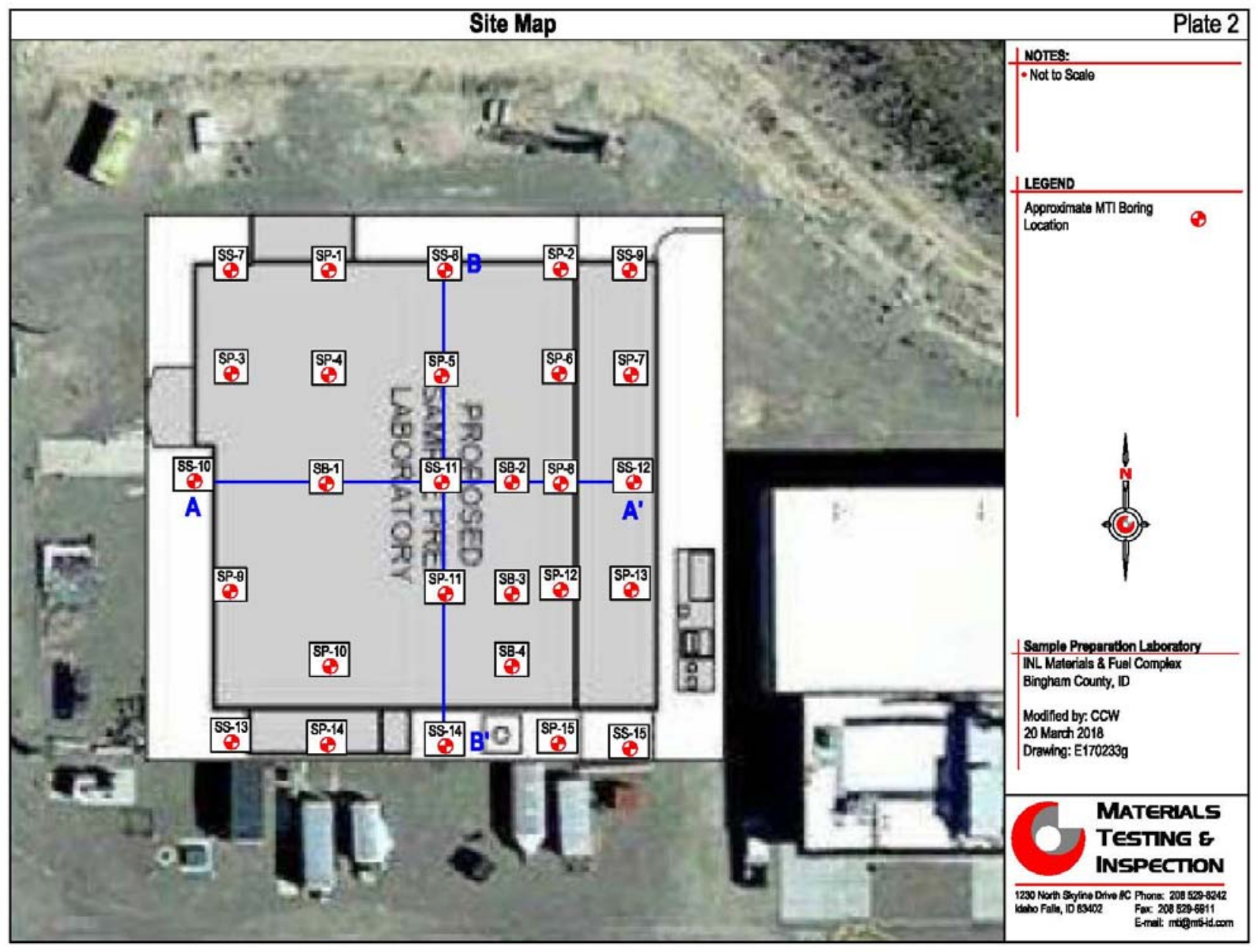




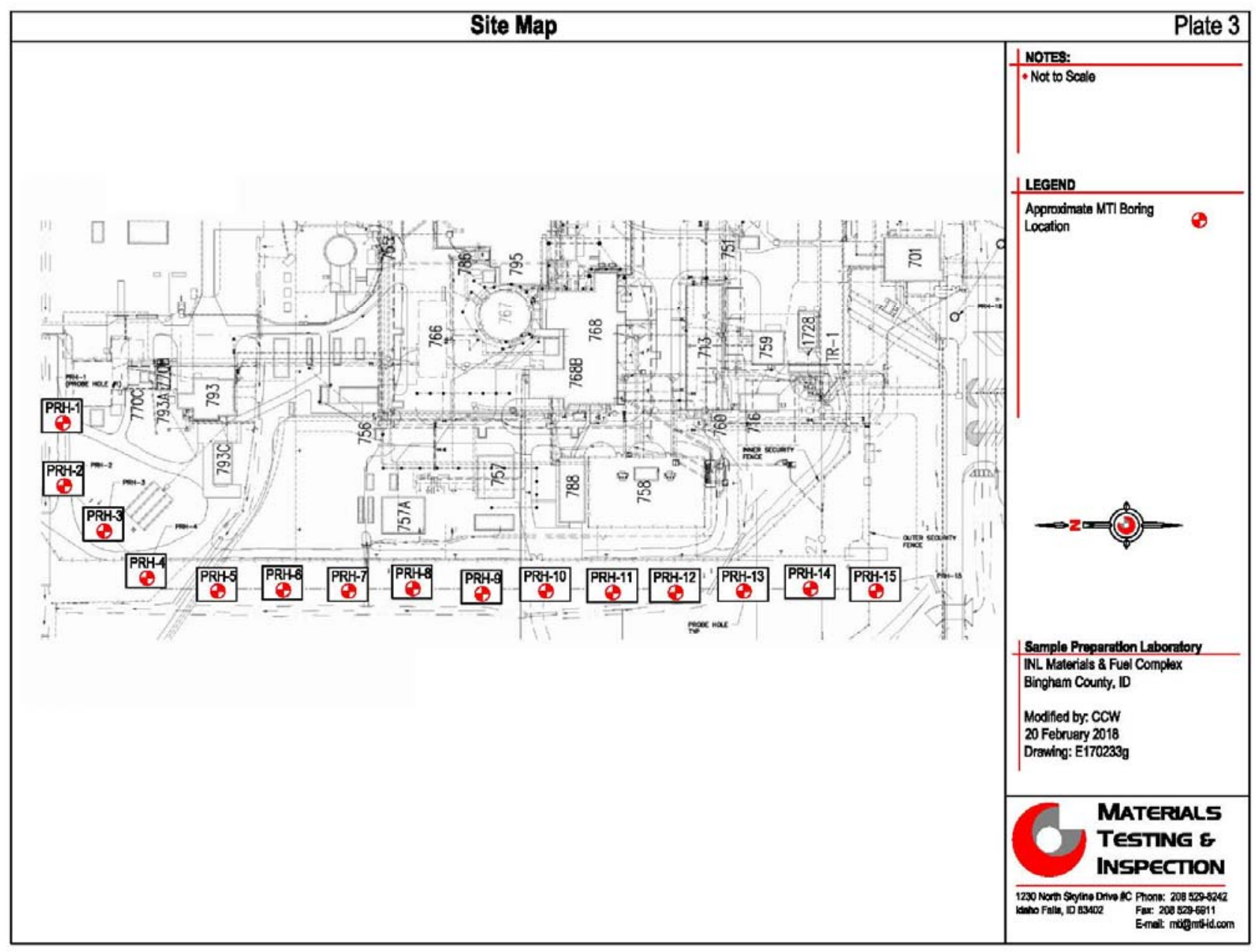




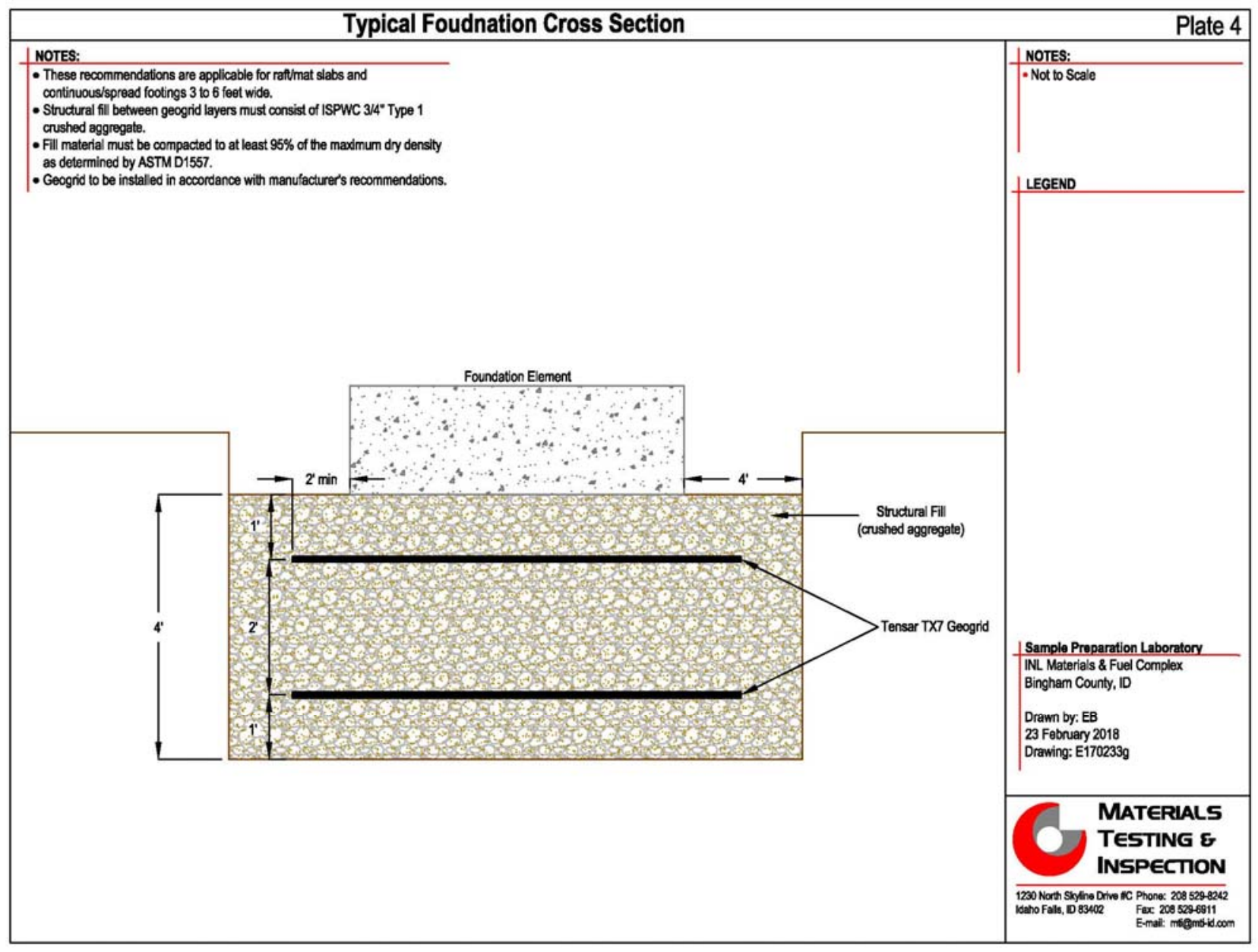




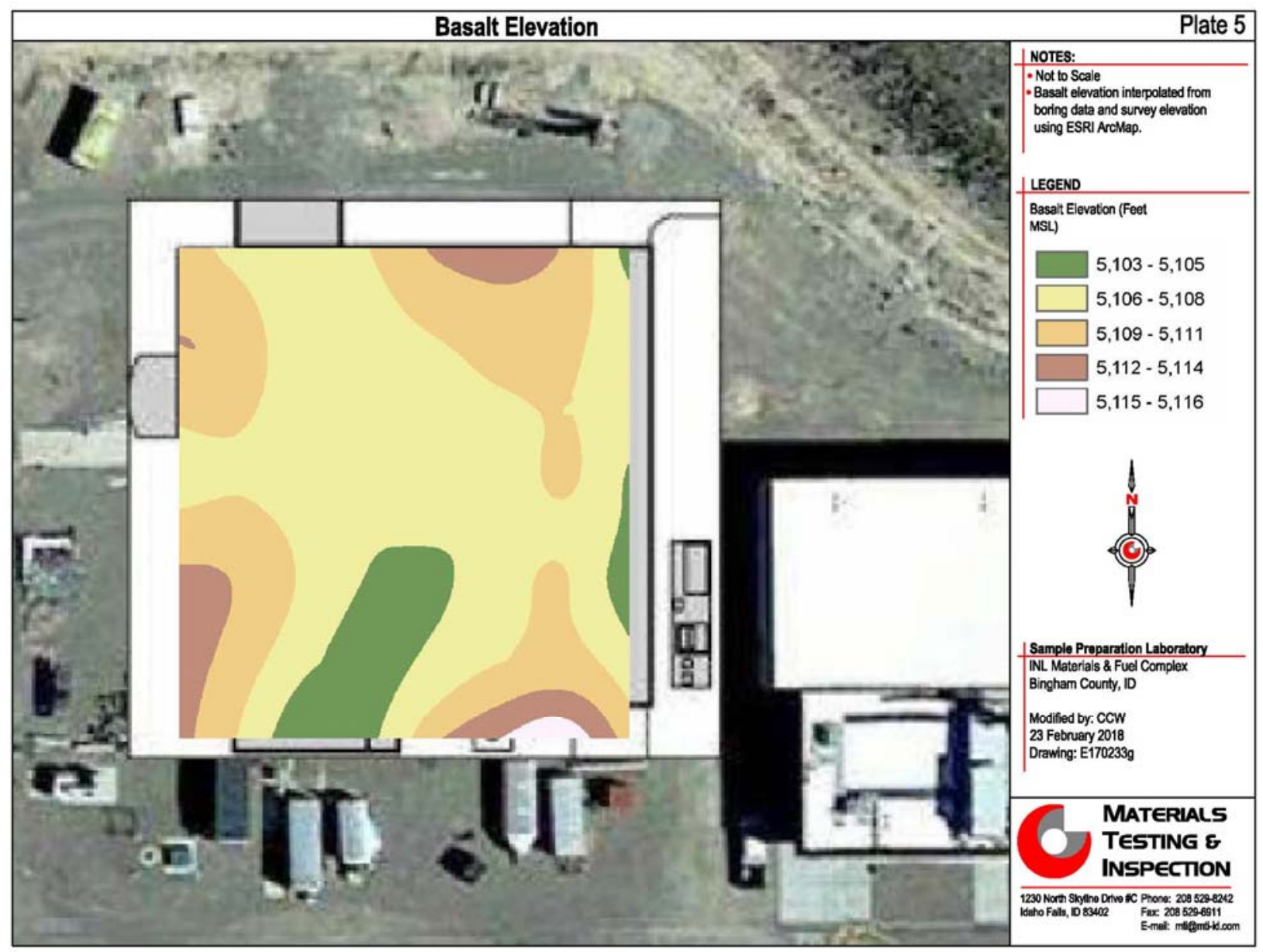




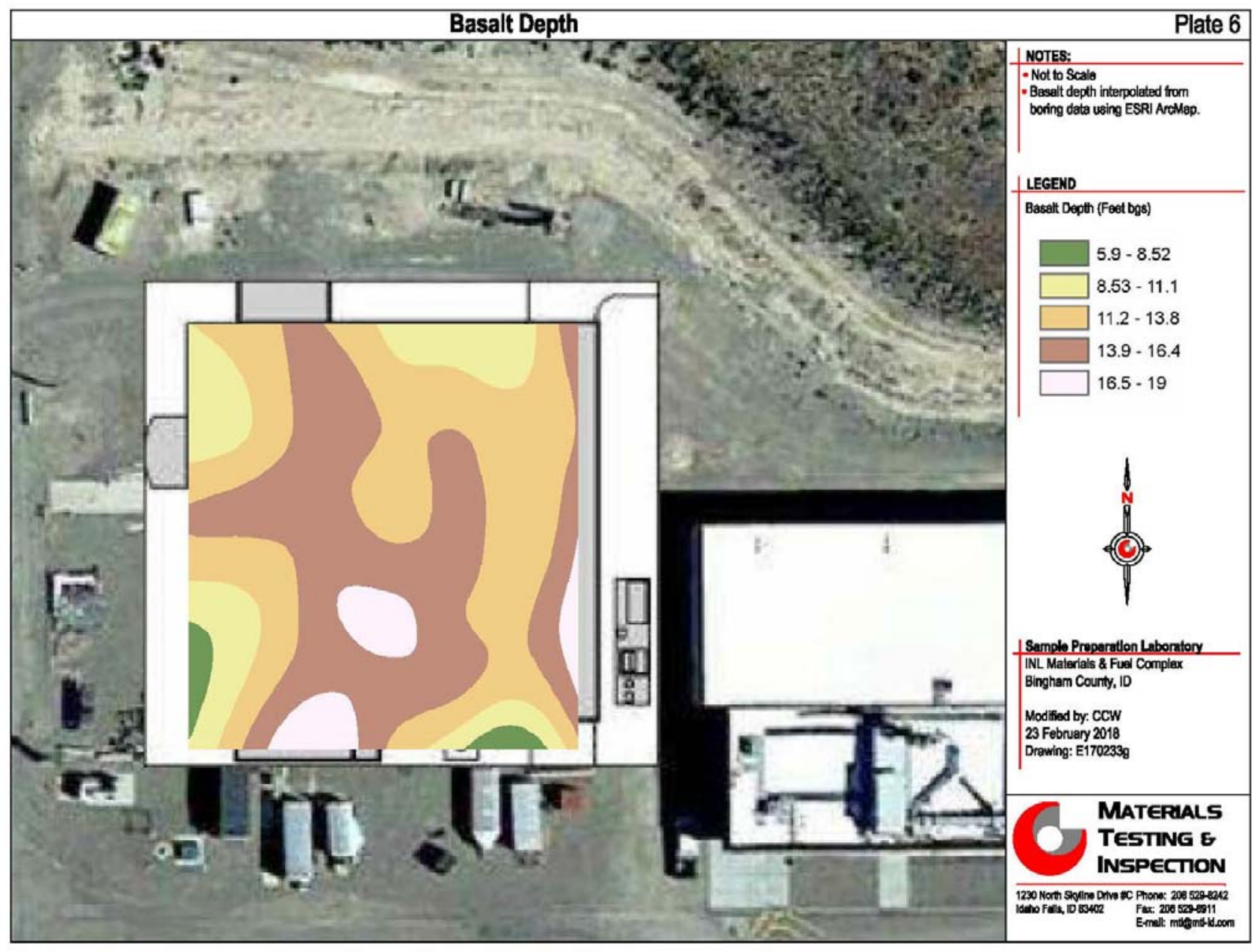




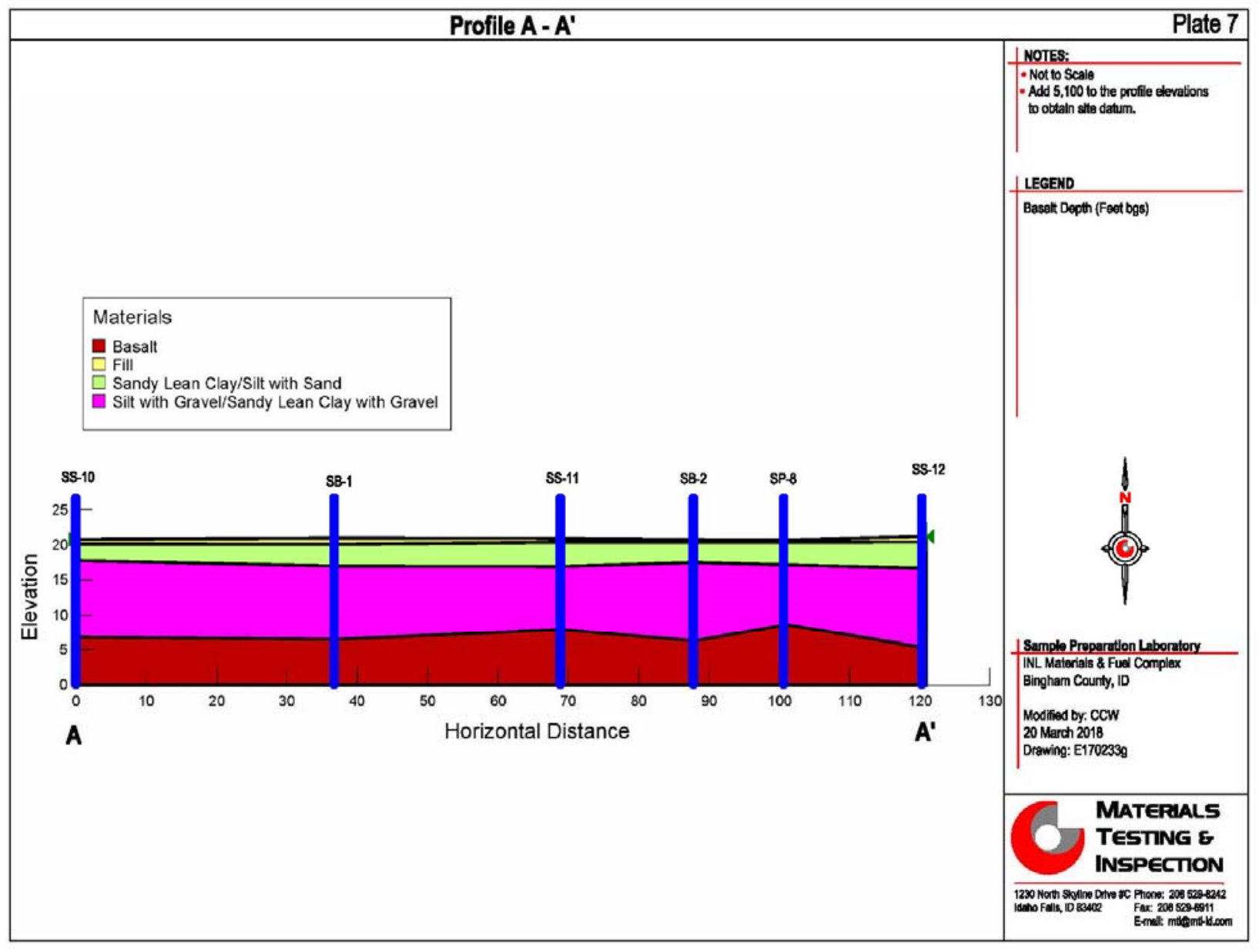




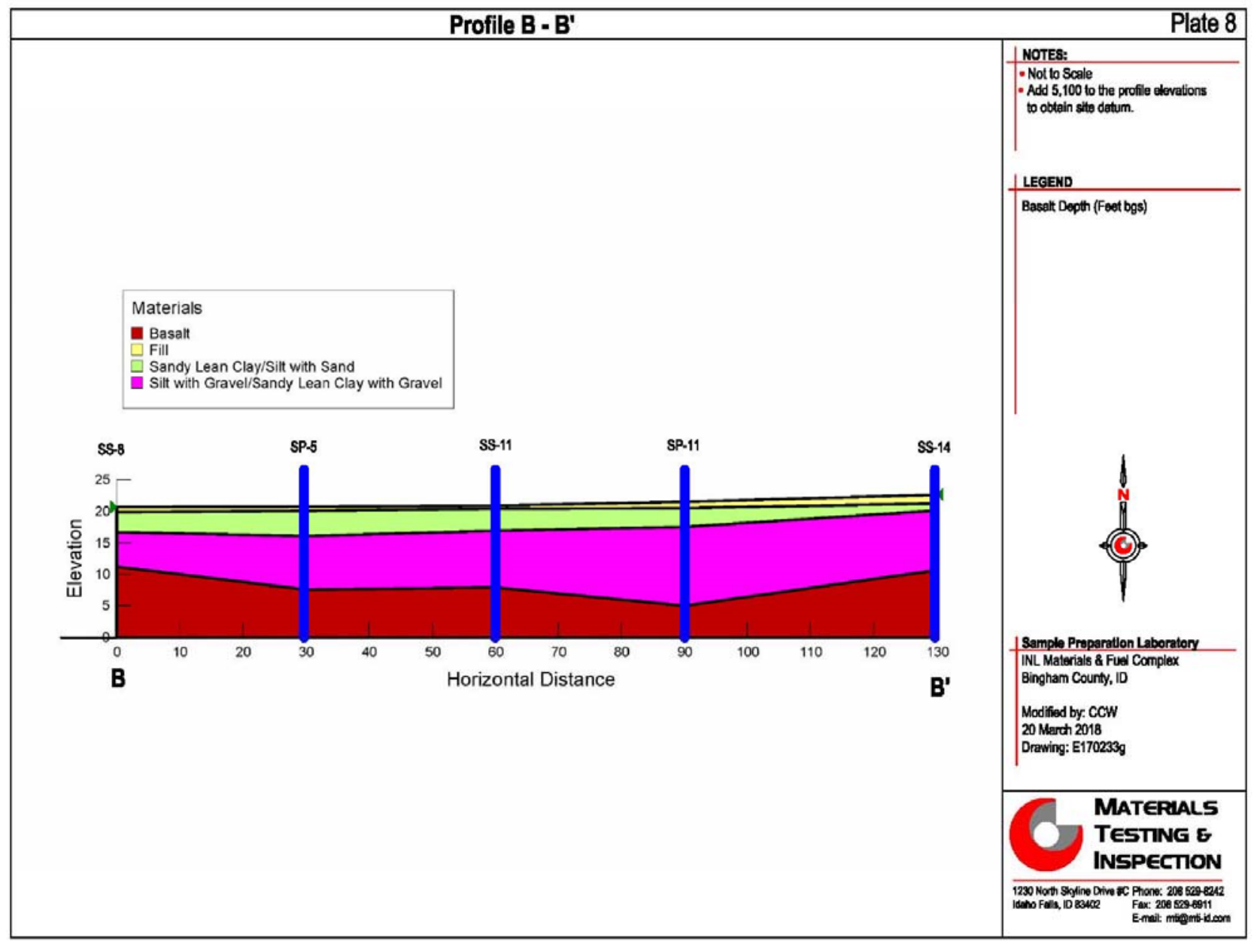



Appendix C

Preliminary Design Calculations 



\begin{tabular}{|c|c|c|c|c|c|c|c|c|c|c|c|c|c|}
\hline \multicolumn{10}{|c|}{ COLLECTION SYSTEM CALCULATIONS } \\
\hline
\end{tabular}




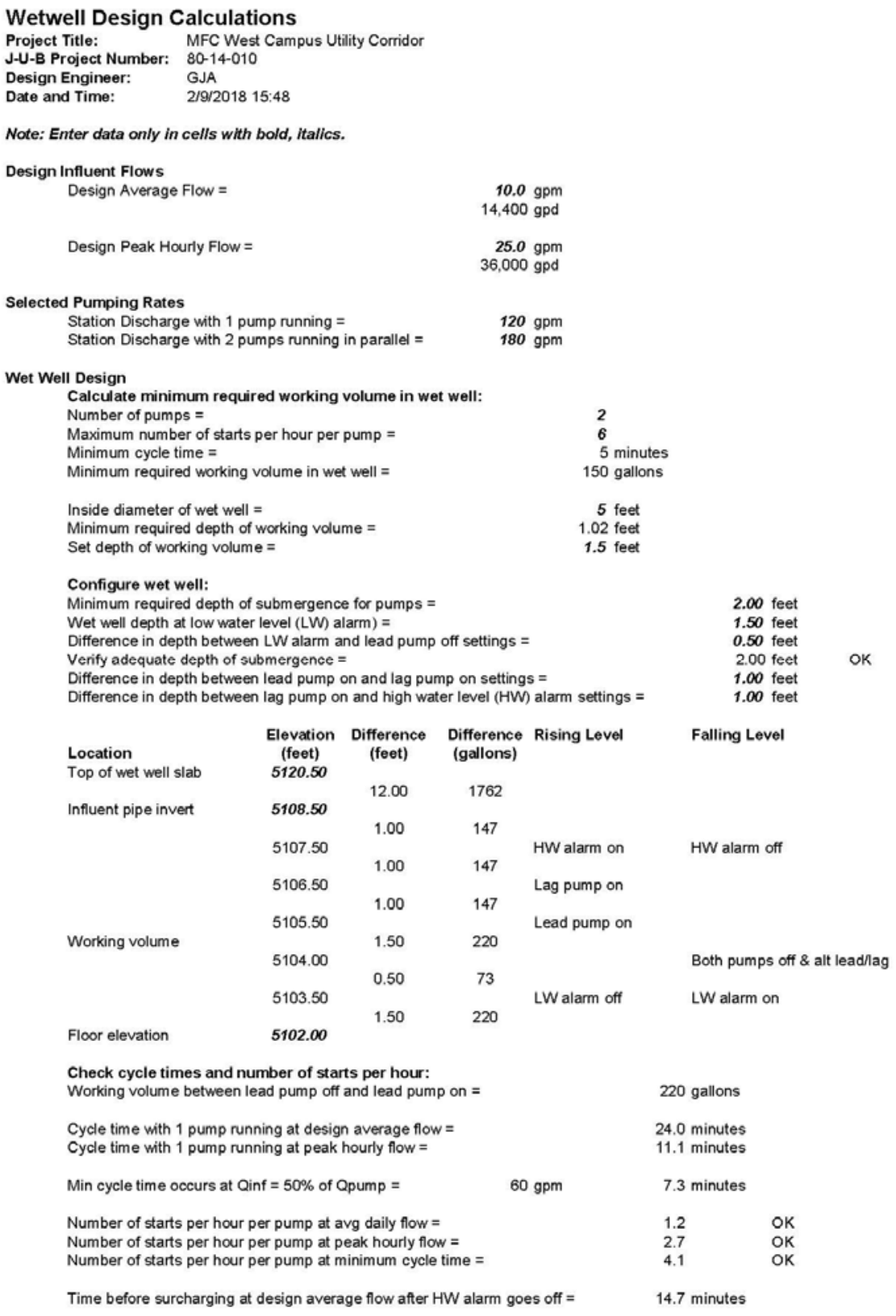




\section{Pump-System Curve Calculations}

Project Title:

J-U-B Project Number:

MFC West Campus Utility Corridor

Design Engineer:

80-14-010

Date and Time:

2/9/2018 15:48

Note: Enter data only in cells with bold, italics.

Force Main Data

\begin{tabular}{lr} 
Face Piping (from pump through valve vault) & \\
\hline Hazen-Williams "C" factor for new pipe & 120 \\
Hazen-Williams "C" factor for old pipe & 110 \\
Length from valve vault to wetwell & 8 feet \\
Length of face piping in wetwell & 15 feet \\
Total Force Main & 23 feet \\
Pipe Diameter (I.D.) & 4.00 inches \\
Pipe "R" & 0.08 \\
Cross Sectional Area & 0.09 sq.ft.
\end{tabular}

Force Main (from valve vault to discharge point)

Hazen-Williams " $C$ " factor for new pipe

Hazen-Williams " $\mathrm{C}$ " factor for old pipe

Length from valve vault to discharge point

Total Force Main

Pipe Diameter (I.D.)

Pipe "R"

Cross Sectional Area

Volume per LF

Total Volume of Force Main

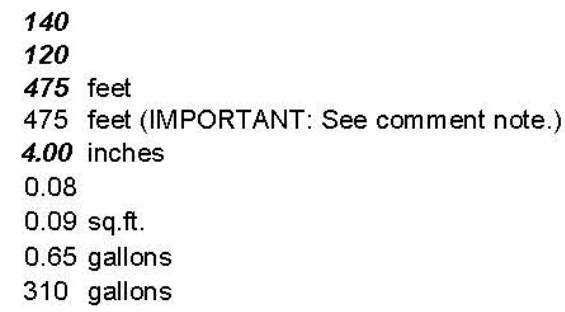

Minor Losses

Item

Face Piping (from pump through valve vault)

ENTRANCE

GATE VALVE

GLOBE VALVE

90 ELBOW

45 ELBOW

CHECK VALVE

SWING CHECK VALVE

PLUG VALVE

$\mathrm{Kv}$

0.5
0.2
10.0
0.5
0.3
1.7
2.5
1.4

Force Main (from valve vault to discharge point)

TEE run

TEE branch

45 ELBOW

$4 \times 3$ Reducer

EXIT

0.4
1.1
1.0
0.2
1.0

Total

$\begin{array}{ll}\mathbf{1} & 0.5 \\ \mathbf{1} & 0.2 \\ 0 & 0.0 \\ \mathbf{3} & 1.5 \\ \boldsymbol{0} & 0.0 \\ \mathbf{1} & 1.7 \\ \boldsymbol{0} & 0.0 \\ \boldsymbol{0} & 0.0 \\ \text { COEF. } & 3.9\end{array}$

TOTAL COEF. $=\quad 3.9$

$\begin{array}{ll}0 & 0.0\end{array}$

$0 \quad 0.0$

$4 \quad 4.0$

$0-0.0$

TOTAL COEF. $=5.0$ 
Elevation and Pump Station Data

Invert elevation of force main at discharge $\mathrm{MH}$

Invert elevation at high point of force main

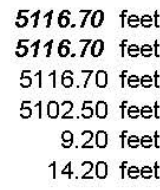

Centerline elevation of pump volutes

Min static head lift

Max static head lift

Hayward Gordon CHOPX 3-A Pump

(2) Parallel - Hayward Gordon CHOPX 3-A Pump

\section{ENTER PUMP CURVES:}

Hayward Gordon CHOPX 3-A Pump

With one pump running:

$\begin{gathered}\text { Pump Q } \\ \text { Range } \\ \text { GPM }\end{gathered}$
0
50
100
150
200
250
300
350

Pump H From Curve

(feet)

$\begin{array}{rr}0 & 20 \\ 50 & 19 \\ 100 & 18 \\ 150 & 16 \\ 200 & 14 \\ 250 & 12 \\ 300 & 10 \\ 350 & 8\end{array}$

With two pumps running in parallel:

$\begin{array}{rr}\begin{array}{c}\text { Pump Q } \\ \text { Range } \\ \text { GPM }\end{array} & \begin{array}{c}\text { Pump H } \\ \text { From Curve } \\ \text { (feet) }\end{array} \\ 0 & 20 \\ 100 & 19 \\ 200 & 18 \\ 300 & 16 \\ 400 & 14\end{array}$


ENTER SYSTEM CURVES:

\begin{tabular}{|c|c|c|c|c|c|c|c|c|c|c|c|}
\hline System Curve for Case \#1: High wetwel| & ith new pipe. & & Face Piping if & from pumpt & through valve & vault) & Force Main (fre & om valve vas & ult to discharg & ge point & \\
\hline & & & Pipe & Pipe Frict & Minor Loss & DYNAMIC & Pipe & Pipe Frict & Minor Loss & DYNAMIC & MIN. \\
\hline Design Condition & Sys Curve $Q$ & Sys Curve Q & $\begin{array}{c}\mathrm{v} \\
\mathrm{v}\end{array}$ & $\mathrm{Hf}$ & $\mathrm{HL}$ & HEAD & $\mathrm{v}$ & $\mathrm{Hf}$ & $\mathrm{HL}$ & HEAD & TDH \\
\hline & $\begin{array}{ll}\text { GPM } & 0\end{array}$ & & FPS 0.0 & (FT) 0.0 & (FT) 0.0 & ${ }^{(\mathrm{FT})} 0.0$ & FPS 0.0 & ${ }^{(\mathrm{FT})} 0.0$ & (FT) 0.0 & & ${ }^{(\mathrm{FT})}{ }_{9.2}$ \\
\hline & 15 & 21,600 & 0.4 & 0.0 & 0.0 & 0.0 & 0.4 & 0.1 & 0.0 & 0.1 & 9.3 \\
\hline & 30 & 43,200 & 0.8 & 0.0 & 0.0 & 0.1 & 0.8 & 0.3 & 0.0 & 0.4 & 9.6 \\
\hline & 45 & 64,800 & 1.1 & 0.0 & 0.1 & 0.1 & 1.1 & 0.7 & 0.1 & 0.8 & 10.1 \\
\hline & 60 & 86,400 & 1.5 & 0.1 & 0.1 & 0.2 & 1.5 & 1.2 & 0.2 & 1.4 & 10.8 \\
\hline & 75 & 108,000 & 1.9 & 0.1 & 0.2 & 0.3 & 1.9 & 1.8 & 0.3 & 2.1 & 11.7 \\
\hline & 90 & 129,600 & 2.3 & 0.2 & 0.3 & 0.5 & 2.3 & 2.6 & 0.4 & 3.0 & 12.7 \\
\hline & 105 & 151,200 & 2.7 & 0.2 & 0.4 & 0.7 & 2.7 & 3.4 & 0.6 & 4.0 & 13.8 \\
\hline Selected Pumping Rate (120 gpm) & 120 & 172,800 & 3.1 & 0.3 & 0.6 & 0.9 & 3.1 & 4.4 & 0.7 & 5.1 & 15.2 \\
\hline & 135 & 194,400 & 3.4 & 0.4 & 0.7 & 1.1 & 3.4 & 5.5 & 0.9 & 6.4 & 16.6 \\
\hline & 150 & 216,000 & 3.8 & 0.4 & 0.9 & 1.3 & 3.8 & 6.6 & 1.1 & 7.8 & 18.3 \\
\hline & 165 & 237,600 & 4.2 & 0.5 & 1.1 & 1.6 & 4.2 & 7.9 & 1.4 & 9.3 & 20.1 \\
\hline & 180 & 259,200 & 4.6 & 0.6 & 1.3 & 1.9 & 4.6 & 9.3 & 1.6 & 10.9 & 22.0 \\
\hline & 195 & 280,800 & 5.0 & 0.7 & 1.5 & 2.2 & 5.0 & 10.8 & 1.9 & 12.7 & 24.1 \\
\hline System Curve for Case \#2: High wetwel & ith old pipe. & & Face Piping of & from pumpt & hrough valve & vaults & in $/$ fri & al & & & \\
\hline & & & Pipe P & Pipe Frict & Minor Loss & DYNAMIC & Pipe & Pipe Frict & Minor Loss & DYNAMIC & $\operatorname{MAX}$ \\
\hline Design Condition & Sys Curve Q & Sys Curve $Q$ & $\mathrm{v}$ & $\mathrm{Hf}$ & $\mathrm{HL}$ & HEAD & $\mathrm{v}$ & $\mathrm{Hf}$ & $\mathrm{HL}$ & HEAD & TDH \\
\hline & GPM & & FPS & (FT) & (FT) & (FT) & FPS & (FT) & (FT) & (FT) & (FT) \\
\hline & 0 & & 0.0 & 0.0 & 0.0 & 0.0 & 0.0 & 0.0 & 0.0 & & 9.2 \\
\hline & & 21,600 & 0.4 & & & 0.0 & 0.4 & 0.1 & 0.0 & 0.1 & 9.4 \\
\hline & 30 & 43,200 & 0.8 & 0.0 & 0.0 & 0.1 & 0.8 & 0.4 & 0.0 & 0.5 & 9.8 \\
\hline & 45 & 64,800 & 1.1 & 0.1 & 0.1 & 0.1 & 1.1 & 1.0 & 0.1 & 1.1 & 10.4 \\
\hline & 60 & 86,400 & 1.5 & 0.1 & 0.1 & 0.2 & 1.5 & 1.6 & 0.2 & 1.8 & 11.2 \\
\hline & 75 & 108,000 & 1.9 & 0.1 & 0.2 & 0.4 & 1.9 & 2.4 & 0. & 2.7 & 12.3 \\
\hline & 90 & 129,600 & 2.3 & 0.2 & 0.3 & 0.5 & 2.3 & 3.4 & 0.4 & 3.8 & 13.5 \\
\hline & 105 & 151,200 & 2.7 & 0.3 & 0.4 & 0.7 & 2.7 & 4.6 & 0.6 & 5.1 & 15.0 \\
\hline Selected Pumping Rate (120 gpm) & 120 & 172,800 & 3.1 & 0.3 & 0.6 & 0.9 & 3.1 & 5.8 & 0.7 & 6.6 & 16.7 \\
\hline & 135 & 194,400 & 3.4 & 0.4 & 0.7 & 1.1 & 3.4 & 7.3 & 0.9 & 8.2 & 18.5 \\
\hline & 150 & 216,000 & 3.8 & 0.5 & 0.9 & $1.4]$ & 3.8 & 8.8 & 1.1 & 10.0 & 20.5 \\
\hline & 165 & 237.600 & 4.2 & 0.6 & 1.1 & 1.7 & 4.2 & 10.5 & 1.4 & & 22.8 \\
\hline & & 259,200 & 4.6 & 0.7 & 1.3 & 2.0 & 4.6 & 12.3 & 1.6 & 140 & 25.2 \\
\hline & 195 & 280,800 & 5.0 & 0.8 & 1.5 & 2.3 & 5.0 & 14.3 & 1.9 & 16.2 & 27.8 \\
\hline
\end{tabular}




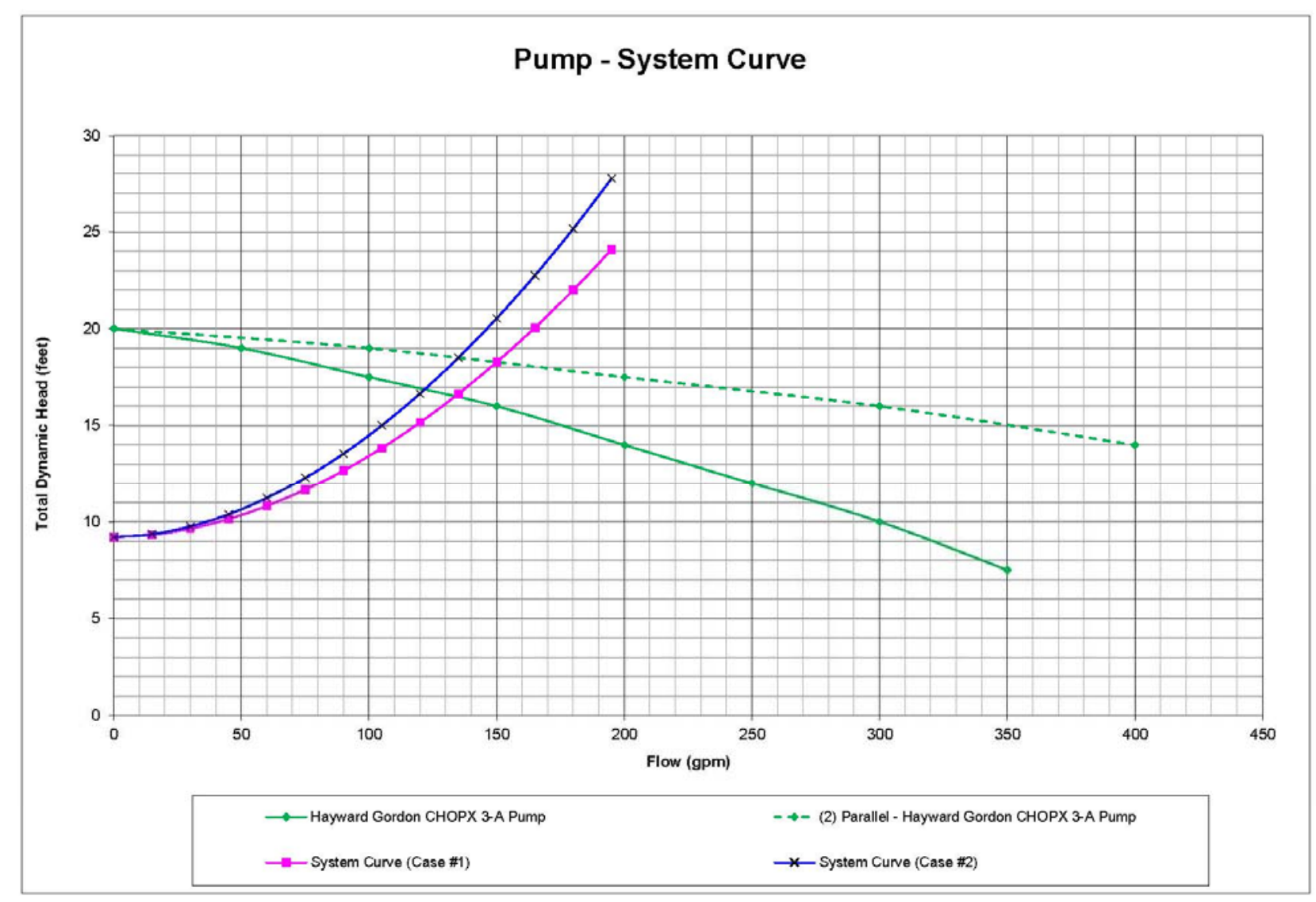

